Universidade de São Paulo

Faculdade de Saúde Pública

\title{
NARRATIVAS SOBRE DESERÇÃO E REINSERÇÃO FAMILIAR DE CRIANÇAS E ADOLESCENTES QUE HABITARAM A RUA E A INSTITUIÇÃO DE ACOLHIMENTO
}

\section{PATRÍCIA MARTINS KHATTAR}

\begin{abstract}
Dissertação de Mestrado apresentada ao Programa de Saúde Pública, na Faculdade de Saúde Pública da Universidade de São Paulo, como requisito à obtenção de título de mestre em Saúde Pública.

Orientador: Prof. Dr. Rubens de Camargo Ferreira Adorno.
\end{abstract}

SÃO PAULO 


\title{
NARRATIVAS SOBRE DESERÇÃO E REINSERÇÃO FAMILIAR DE CRIANÇAS E ADOLESCENTES QUE HABITRAM A RUA E A INSTITUIÇÃO DE ACOLHIMENTO
}

\section{PATRÍCIA MARTINS KHATTAR}

\begin{abstract}
Dissertação de Mestrado apresentada ao Programa de Saúde Pública, na Faculdade de Saúde Pública da Universidade de São Paulo, como requisito à obtenção de título de mestre em Saúde Pública.
\end{abstract}

Orientador: Prof. Dr. Rubens de Camargo Ferreira Adorno.

SÃO PAULO 
É expressamente proibida a comercialização deste documento, tanto na sua forma impressa como eletrônica. A reprodução e divulgação total ou parcial deste trabalho é permitida, exclusivamente, para fins acadêmicos e científicos, desde que na reprodução figure a identificação da autora, título, instituição e ano da dissertação. 


\title{
PATRÍCIA MARTINS KHATTAR
}

NARRATIVAS SOBRE DESERÇÃO E REINSERÇÃO FAMILIAR DE CRIANÇAS E ADOLESCENTES QUE HABITRAM A RUA E A INSTITUIÇÃO DE ACOLHIMENTO

\author{
Dissertação de Mestrado apresentada ao \\ Programa de Saúde Pública, na Faculdade de \\ Saúde Pública da Universidade de São Paulo, \\ como requisito à obtenção de título de mestre em \\ Saúde Pública.
}

Aprovada em

Prof ${ }^{\circ}$

Prof ${ }^{\circ}$

Prof ${ }^{\circ}$ 
O presente trabalho foi realizado com apoio da Coordenação de Aperfeiçoamento de Pessoal de Nível Superior - Brasil (CAPES) - Código de Financiamento 001. 
À minha mãe e a meu pai por me concederem uma infância linda, alegre e singela, pelo ensino sobre o valor do conhecimento e por toda dedicação! 


\section{Agradecimentos}

Minha alegria e gratidão por todos que foram importantes nesta trajetória.

Àquele em quem estão escondidos todos os tesouros da sabedoria e da ciência ${ }^{1}$, pela vida colorida por Tua divina graça!

Ao meu companheiro Fábio pelo suporte e doce presença nos dias leves ou árduos.

Ao Prof. Dr. Rubens Adorno pelo afeto, respeito, acolhimento investidos no nosso vínculo, pelos posicionamentos intensos que contribuíram com tantas reflexões, prosas e recomendações permeadas de brilhantismo, profundidade e ética que lhe são peculiares.

Às preciosas e minuciosas recomendações e debates de ideias dos participantes das bancas examinadoras que permitiram lapidar o trabalho: $\operatorname{Prof}^{\mathrm{a}} \mathrm{Dr}^{\mathrm{a}}$ Ana Paula Malfitano,

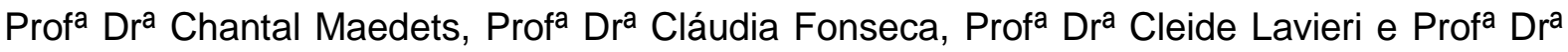
Heloísa Szymanski.

Aos que foram solícitos e receptivos durante o intercâmbio acadêmico internacional, dedicando tempo para diálogos e pensares importantes para os caminhos desta pesquisa. As equipes dos abrigos e da Comissão de Proteção da Infância e Juventude que oportunizaram que eu pudesse conhecer um pouco da realidade de tais instituições.

Ao Prof ${ }^{\circ}$ Dr. Luiz Fernandes em parceria com a Universidade do Porto, pela leveza e simpatia que permeou as narrativas que trocamos sobre a minha proposta de investigação, oferecendo nortes e rede de contatos com instituições e profissionais pivotais para temática do estudo.

À Valéria Pássaro e ao José Soró pelos saberes compartilhados ao mostrarem na prática que o caminho da excelência e inovação é possível no acolhimento institucional infatojuvenil.

Aos amigos, à família Felizes, aos meus familiares, parceiros acadêmicos e profissionais que disponibilizaram sua escuta acolhedora e incentivadora durante o processo de construção deste trabalho e de sua idealização por terem compartilhado suas impressões e enriquecido minhas perspectivas.

Às famílias e crianças que tornaram tudo isso possível ao partilharem suas tocantes histórias e tempo comigo, quando me ensinaram mais sobre amor, conexão relacional, resiliência e esperança.

Aos meus colegas profissionais que se dedicam ao cuidado de crianças buscando analisar e reinventar o fazer técnico e afetivo do cotidiano em busca de fortalecer a dignidade e garantia de direitos à infância e adolescência.

A todos que de algum modo participaram desta pesquisa, meu carinho e profunda gratidão!

\footnotetext{
${ }^{1}$ Bíblia: Colossenses 2:3.
} 


\section{Infância e Amor}

Uma cidade onde todas as crianças possam correr,

Brincar, sorrir

O que sonho para a minha pequena

Sonho para todas as crianças

Como se todas fossem minha família.

Mas é preciso mais que sonho

É preciso fazer uma cidade

Onde as crianças possam habitar com seus modos,

Livres,

Corajosas e

Felizes

Corre minha filha

Brinca

Vai lá

Faz

Outro mundo

Tem que ser inventado

E ele pode ser

Novo.

Vai lá criança, faz.

Faz, minha criança,

Um mundo melhor

Para as crianças. ${ }^{2}$

\footnotetext{
${ }^{2}$ Fellipe dos Anjos, 2019.
} 


\section{KHATTAR, P. M. Narrativas sobre deserção e reinserção familiar de crianças e adolescentes que habitaram a rua e a instituição de acolhimento. 2019 - Dissertação Faculdade de Saúde Pública da USP, São Paulo, 2019.}

\section{RESUMO}

As relações familiares constituem objeto das ações do Estado que, visando a promoção do cuidado e garantia dos direitos infantojuvenis, atende por meio de abrigos crianças e adolescentes que habitaram a rua ou passaram, por diversas razões, pelo processo de deserção familiar. O presente estudo teve como objetivo analisar o processo de reinserção familiar de crianças que habitaram a rua e instituições de acolhimento por meio de narrativas de profissionais de abrigos, famílias e das próprias crianças. Adicionalmente, objetivou-se investigar o potencial benéfico e os grandes desafios deste processo que, não raras vezes, incorre em repetidas reinstitucionalizações de crianças previamente reinseridas em suas famílias. A metodologia aplicada foi definida a partir de contribuições teóricas da etnografia e da entrevista etnográfica. Foi realizado acompanhamento de 2 famílias atendidas por uma instituição de acolhimento infantojuvenil por meio de entrevistas etnográficas, visitas presenciais e registros em diários de campo. Também foram analisados documentos da instituição de acolhimento para contribuir com o levantamento da trajetória e das experiências das crianças e familiares entrevistados. A análise de dados ocorreu em articulação teórica com a perspectiva dos Estudos Sociais da Infância, visando gerar contribuições enriquecedoras para o campo de pesquisa, diante de um cenário social permeado por conquistas contemporâneas, bem como pelos desafios das políticas públicas voltadas à defesa do direito à convivência familiar e comunitária da criança e do adolescente. Com os resultados obtidos, foi possível concluir que o manejo e a qualidade de escuta das crianças e familiares por parte da equipe técnica do serviço de acolhimento e de toda a rede de garantia de direitos pode oferecer subsídios ou obstáculos ao processo de reinserção familiar de acordo com as concepções de família que os profissionais adotam e norteiam a sua atuação prática.

Palavras-chaves: Crianças; Adolescentes; Situação de Rua; Reinserção Familiar; Acolhimento Institucional; Políticas Públicas. 


\title{
Narratives on the family desertion and reisertion of children and teenagers habiting the street and a host institition. 2019 - Dissertação Faculdade de Saúde Pública da USP, São Paulo, 2019. Portuguese.
}

\begin{abstract}
Family relations are the object of the State's actions, which, aiming at promoting care and guaranteeing children's rights, provide childcare services to children and adolescents who lived in the streets or, for various reasons, went through the process of family desertion. This study analyzed the process of family reintegration of children who lived in the streets and childcare institutions through narratives of shelter professionals, families and the children themselves. Additionally, this research aimed to investigate the beneficial potential and the main challenges of this process that often incurs repeated reinstitutionalizations of children previously reinserted in their families. The applied methodology was defined from theoretical contributions of ethnography and ethnographic interview. Two families assisted by a childcare institution were accompanied through ethnographic interviews, presential visits and field diary records. Documents from the host institution were also analyzed to contribute to the researched children and families' trajectory and experiences mapping. Data analysis was conducted in theoretical articulation with the perspective of the Social Studies of Childhood, aiming to generate enriching contributions to this research field, facing a social scenario permeated by contemporary achievements, as well as the challenges of public policies aimed to defending the right to family and community life of children and adolescents. With the results obtained, it was concluded that the management and listening quality of children and family members by the technical staff of the care services can offer subsidies or obstacles to the process of family reintegration according to the family conceptions that professionals adopt and with which guide their practice. ${ }^{3}$
\end{abstract}

Keywords: Children; Adolescents; Street situation; Family Reinsertion; Institutional Reception; Public Policy.

\footnotetext{
${ }^{3}$ This work was financed in part by the Coordenação de Aperfeiçoamento de Pessoa de Nível Superior - Brasil (CAPES) - Financing Code 001.
} 


\section{Lista de Abreviaturas}

CCA - Centro para Crianças e Adolescentes

CRAS - Centro de Referência da Assistência Social

CREAS - Centro Especializado de Referência da Assistência Social

CT - Conselho Tutelar

ECA - Estatuto da Criança e do Adolescente

CAPSi - Centro de Atenção Psicossocial Infantojuvenil

IPEA - Instituto de Pesquisa Econômica Aplicada

MP - Ministério Público

ROCAM - Ronda Ostensiva Com Apoio de Motocicletas

SAICA - Serviço de Acolhimento Institucional Para Crianças e Adolescentes

TEA - Transtorno do Espectro do Autismo

UBS - Unidade Básica de Saúde

\section{Lista de llustrações}

Figura 1.

Figura 2.

Figura 3. 


\section{SUMÁRIO}

1. MEMORIAL ACADÊMICO Erro! Indicador não definido.

2. APRESENTAÇÃO Erro! Indicador não definido.

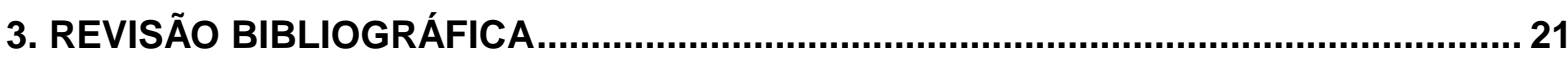

3.1 A Circulação de Crianças e Adolescentes entre Ruas e Abrigos ............................... 21

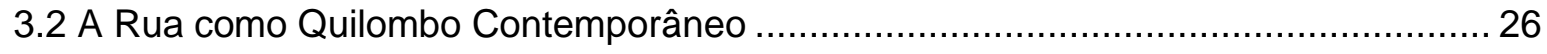

3.3 Ciranda entre famílias e redes de afeto ........................................................ 28

3.4 Contribuições Antropológicas e Concepções de Família ........................................ 31

3.5 Processos históricos dos filhos do Estado, da mídia e da família ............................... 33

3.6 Estado herói versus família algoz: Repercussões de nomenclaturas na cultura

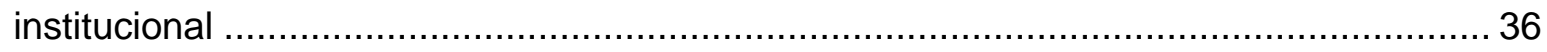

3.7 Sexualidade de Crianças e Adolescentes na Instituição de Acolhimento................... 43

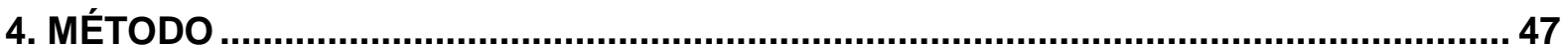

5. ENTREVISTAS ETNOGRÁFICAS DO DIÁRIO DE CAMPO ....................................... 50

5.1 Narrativas de crianças, familiares e equipes institucionais ................................... 50

5.2 Narrativas de Valentina, Celeste e profissionais .............................................. 51

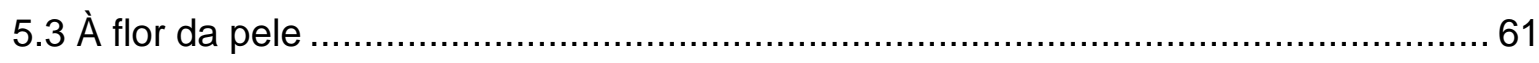

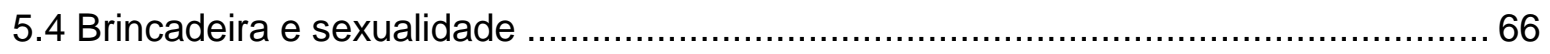

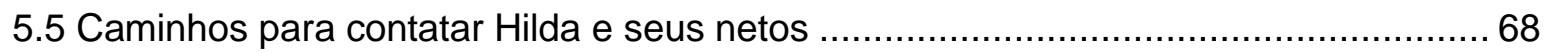

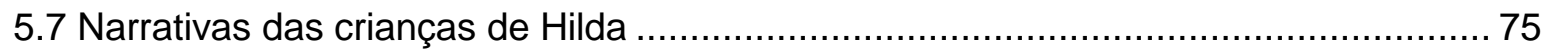

5.8 Narrativas na instituição de acolhimento das crianças ............................................. 83

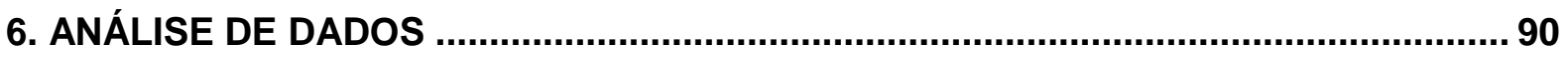

6.1 Valentina entre reinserções e deserções ............................................................. 90

6.2 Concepções de família para Valentina, Celeste e profissionais .............................. 100

6.3 Netos de Hilda entre reinserções e deserções ..................................................... 101

6.4 Concepções de família para Hilda, crianças e profissionais ................................... 108

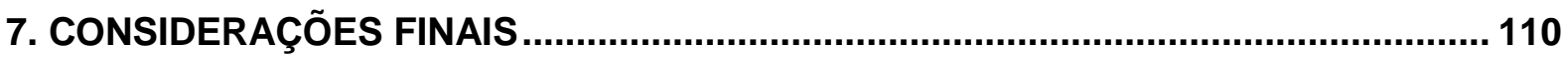

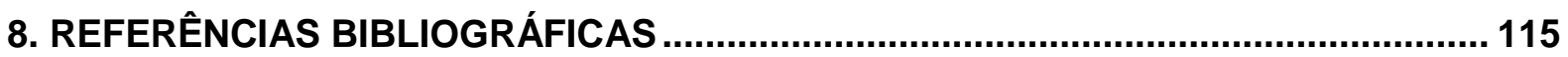

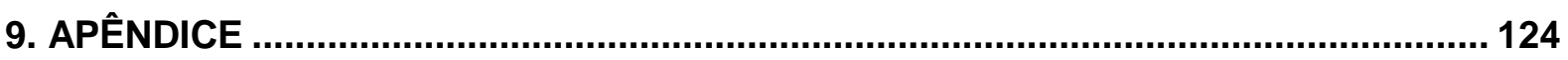

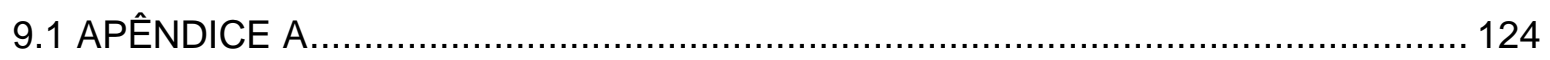

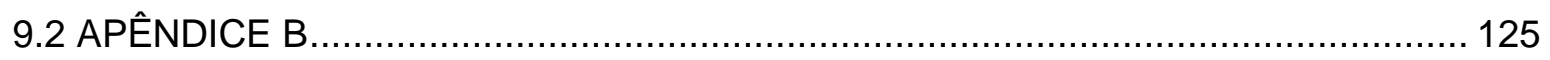

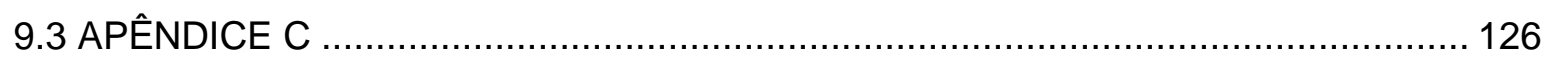

10. ANEXO Edital de Conveniamento de SAICAs .................................................... 127 


\title{
1. MEMORIAL ACADÊMICO
}

\begin{abstract}
São as crianças que, sem falar, nos ensinam as razões para viver. Elas não têm saberes a transmitir. No entanto, elas sabem o essencial da vida. O essencial da vida não é o trabalho, mas o brinquedo (Alves, 2014).
\end{abstract}

Nascida na periferia da zona norte paulistana, desde a adolescência houve um despertar para as problemáticas sociais e a busca por justiça social, dentro do meu horizonte de possibilidades, por meio do engajamento social, viabilizado na intensa participação em projetos sociais e humanitários, muitos deles desenvolvidos em parcerias com Organizações Não Governamentais e a minha comunidade espiritual de fé cristã.

No Morro do Borel, localizado no Rio de Janeiro, dediquei diversas das minhas férias, em anos consecutivos a partir de 2010, para realizar ações desenvolvidas e planejadas de acordo com a demanda local, alcançando todos os públicos etários, com equipes multidisciplinares de voluntários que atuavam no âmbito da educação e da saúde.

Para ilustrar brevemente algumas atividades, em certo momento, os líderes comunitários expressaram que as crianças e os adolescentes tinham os agentes do tráfico de substâncias psicoativas como suas referências, visto que eram os que se sobressaiam economicamente naquele contexto social. Então, atividades lúdicas foram estruturadas para ampliar o repertório de possibilidades profissionais. No fim, ao perguntarmos a uma criança o que queria ser quando crescesse, uma que no início tinha dito traficante, transformou sua resposta ao declarar o desejo de que queria ser bombeiro. Semelhante mudança ocorreu no discurso de muitas das crianças que participaram do projeto.

Nos primeiros anos de atuação no projeto "Pé no Morro", era necessário adotar diversas medidas de segurança, visto que consistia em período de forte embate entre agentes da ilegalidade e policiais. Havia crianças que aparentavam ter cerca de onze anos, enquanto seguravam metralhadoras grandes pelos becos e vielas. Toda a equipe somente subia 0 morro devidamente uniformizada com a camiseta do projeto, bem como acompanhada por líderes comunitários e após consentimento do chefe do morro, isto é, líder do tráfico de drogas. 
Outros projetos foram no recinto da minha ancestralidade: em quilombos. Primeiramente no de Pedro Cubas, em 2012, depois no da Fazenda de Pincinguaba, em 2016. De semelhante modo, havia uma equipe com múltiplas vertentes profissionais, engajadas em concretizar o idealizado pelos líderes comunitários, dentre ações com crianças até idosos, com profissionais da saúde, educação e demais campos relevantes para a agenda da região.

Em 2013, a atuação em Roraima, na região Amazônica, junto às etnias indígenas Yanomami e Macuxi fora oportuno contribuir em iniciativas pautadas no enfrentamento da exploração sexual e comercial de crianças e adolescentes, problemática grave na região, ao disseminar conhecimento referente aos direitos da criança e do adolescente, bem como sobre equipamentos de Políticas Públicas para denúncia, proteção e tratamento de questões associadas à abrangente esfera da violência sexual infantojuvenil. As equipes completas dos projetos supracitados atuavam com trabalho voluntário.

Enquanto estudava na escola pública, conversava com meus colegas da 8ª série sobre meu desejo de ser psicóloga. Conforme o tempo transcorreu, a vocação confirmou-se. Ao cursar Psicologia, no último ano, quando é necessário optar por três estágios a serem realizados, elegi um Hospital Pediátrico, um Centro de Criança e Adolescentes e a Psicoterapia Infantil.

Conclui a graduação em Psicologia na Universidade Presbiteriana Mackenzie em 2012, encantada pela Psicologia Social, pela consonância com a minha trajetória e com aquilo que era e é visceral para mim, ou seja, enfrentar as angústias sociais presenciadas desde cedo no entorno de meu bairro.

A primeira experiência que ansiava ter enquanto psicóloga era fazer parte do Projeto Quixote, e assim foi na região da Luz, referida como "Cracolância". Organização muito bemconceituada no cuidado de crianças e adolescentes em situação de rua, voltada ao desenvolvimento de trabalho com as famílias em articulação com a rede intersetorial de serviços.

$\mathrm{Na}$ sequência, em meados de 2013, participei do grupo gestor de um Serviço de Acolhimento para Crianças e Adolescentes (SAICA). Neste percurso tive a experiência de atuar na admirável e conceituada instituição mencionada anteriormente, na coordenação de assembleias, espaços para diálogo em Grupos de Fala que permitiam empoderar a construção de narrativa das crianças e a elaboração de acordos e regras da casa.

Os Grupos de Fala eram destinados para conversas sobre temas plurais elegidos pelas crianças e adolescentes (ansiedade, depressão, sexualidade, etc), e, dentre muitos outros fazeres, estava incluída a questão do trabalho pautado no fortalecimento de laços familiares 
e comunitários. Deste modo, os Grupos de Fala consistiam também em lócus de cuidado com positivos impactos à saúde mental, pelos efeitos terapêuticos oportunizados neste espaço de troca facilitado pelo profissional da psicologia inserido no serviço de acolhimento ou educadores supervisionados e orientados sobre manejo para coordenação de tais grupos.

A experiência mais recente, como psicóloga, consistiu na instituição de acolhimento para grupos familiares de distintas configurações, sobretudo com crianças, serviço denominado Família em Foco. Equipamento da Assistência Social que recebe famílias em situação de rua ou de grave vulnerabilidade social, e onde é realizado o plano de atendimento de forma compartilhada, focado no desenvolvimento da autonomia da família.

Ainda dentro do percurso das problemáticas da infância, contudo desta vez no cenário da África Ocidental, em Dakar, no Senegal, se deu meu engajamento junto a uma equipe multidisciplinar da saúde, educação e do esporte, junto ao Projeto Fabrique de l'Espoir. A priori, estudei francês intensivamente durante um ano no período preparativo para esse intercâmbio profissional.

O foco da minha prática consistiu em coconstruir estratégias para lidar com as dificuldades psicopedagógicas de crianças pré-escolares junto aos seus educadores. Novamente, esse trabalho originou-se dos relatos das necessidades daquele lugar para construção de um plano de intervenção elaborado junto aos líderes da instituição de ensino. Enquanto isso, os demais profissionais atuavam em outras frentes do projeto, como em uma escola de futebol e em uma clínica interdisciplinar que contemplava as especialidades médica, odontológica e fisioterapêutica.

Durante o mestrado, agraciada com financiamento da CAPES em 2018, realizei intercâmbio acadêmico para a Europa, ao passar pela França, em Paris; Portugal, em Lisboa, Porto, Leiria, Braga e Guimaraes; e por fim na Inglaterra, em Londres. Na passagem por diversos países, a dedicação de maior de tempo, com vínculo universitário, transcorreu em Portugal, onde conheci instituições de acolhimento e serviços da rede de proteção infantojuvenil, ao favorecer uma reflexão comparativa da realidade brasileira com a portuguesa.

Atualmente, de forma paralela à atenção direcionada à pesquisa de mestrado, tenho estudado e envolvido-me com experiências inclinadas à primeira infância. Desta vez no campo da saúde em interface com a educação, ao debruçar-me sobre técnicas e saberes da intervenção precoce em bebês com autismo e outros transtornos do desenvolvimento, por meio do Modelo Precoce de Denver, considerado uma das maiores descobertas científicas para o tratamento do Transtorno do Espectro do Autismo (TEA) devido aos 
resultados intensamente exitosos que têm atingido, até mesmo com crianças que não pontuam mais para o diagnóstico de TEA após receberem cuidado qualificado.

Enfim, não é mera coincidência que o relato acima tenha evidenciado que ao longo do meu caminho e do percurso desenhado, quer estudantil ou profissional, a infância sempre foi visceral. As cores mais vibrantes do meu mundo, vem do colorir das crianças!

\section{APRESENTAÇÃO}

Ubuntu: Eu sou por aquilo que nós somos (LOUW, 1997).

A proposta desta pesquisa surgiu, sobretudo, da trajetória profissional da pesquisadora no campo da Saúde Pública, como Educadora Social e Psicóloga Social voltada ao cuidado de crianças em situação de rua e de vulnerabilidade social, em experiências nacionais e internacionais, desde a região pejorativamente conhecida como "Cracolândia" até a África, conforme minuciosamente explanado na área do Memorial Acadêmico.

Diante deste pano de fundo, a trajetória percorrida desembocou nos caminhos do acolhimento institucional infantojuvenil, por meio da atuação como Psicóloga em uma conceituada organização filantrópica que é considerada referência profissional do acolhimento institucional. Inclusive tal organização já implantou e gerenciou distintos Serviços de Acolhimento Institucional para Crianças e Adolescentes ao longo de duas décadas de trabalho com atuação voltada para grupos familiares com configurações diversificadas. Deste modo, adveio intenso contato e imersão nesse equipamento da Assistência Social.

A partir deste cenário, fora suscitado o questionamento sobre qual seria o resultado obtido ao analisar o processo de reinserção familiar de crianças e adolescentes que viveram no âmbito do acolhimento institucional após terem habitado as ruas? Em linhas gerais, este é o objeto de estudo viabilizado mediante o acompanhamento de dois grupos familiares atendidos por um serviço de acolhimento na cidade de São Paulo, sendo que tal SAICA teve funcionamento excedente a 6 anos.

A instituição aceitou a participação nesta pesquisa a fim de corresponder ao objetivo específico do estudo inclinado a investigar os desdobramentos do retorno ao contexto 
familiar para identificar como os vínculos parentais foram sustentados e fortalecidos ou de qual forma sucederam novas rupturas que, por sua vez, conduziram à reinstitucionalização infantojuvenil. Enfim, buscou-se identificar como foram as experiências parentais no processo de reinserção e deserção familiar, conforme as suas repercussões.

Deste modo, o segundo objetivo específico da pesquisa consistiu em observar as potencialidades e os obstáculos enfrentados no decorrer do processo de reinserção familiar, descrever se os caminhos extra institucionais foram acionados para promoção desta reinserção e expor as vivências apresentadas pelos grupos de familiares participantes deste trabalho articulado em parceria com a instituição de acolhimento e o sistema de garantia de direitos, da qual é partícipe também o Poder Judiciário, o Ministério Público e o Conselho Tutelar.

Em razão, principalmente, da relevância social e acadêmica do engajamento em tal pesquisa enquanto temática com literatura que possui lacunas, apesar das complexidades e adversidades que permeiam o cotidiano da infância e juventude com vivências nas ruas e em Serviços de Acolhimento. Manifesta-se demanda de suma importância para repensar as Políticas Públicas deste setor ao objetivar aprimorar saberes e oferecer subsídios com arcabouço voltado a promover impacto social, para empoderar transformações referentes à garantia de direitos da criança e do adolescente atreladas ao foco na defesa da convivência familiar e comunitária.

Neste estudo, pretendeu-se observar a família como centro da intervenção estatal pela via da institucionalização. Famílias com distintas configurações e dinâmicas relacionais afetadas, de fora para dentro, a medida que este grupo social tornou-se instrumento de práticas provenientes da intervenção de programas assistenciais, buscando desvelar características, implicações do processo de escuta ou não da criança e de sua família no decorrer das intervenções aplicadas no contexto institucional do acolhimento infantojuvenil, especificamente, voltado à reinserção familiar.

Em linhas gerais, a pesquisa foi devolvida alicerçada em inspirações da etnografia, com objetivo de ampliar conhecimentos sobre a realidade de crianças e adolescentes que estiveram em situação de rua e, posteriormente, foram institucionalizados em serviços de acolhimento, focando a atenção no processo de reinserção familiar. Deste modo, objetivouse levantar dados acerca das vicissitudes e repercussões da reintegração familiar a fim de investigar a possível ocorrência de casos que vivenciaram novamente rupturas de vínculos 
parentais, até mesmo por meio da reinstitucionalização, bem como analisar aspectos de casos nos quais os laços afetivos puderam ser fortalecidos, ressignificados e sustentados, portanto, dispensando as recorrentes institucionalizações.

Mais especificamente, o objetivo foi concretizado em parceria com a coordenação do serviço de acolhimento no qual as crianças abarcadas pela Pesquisa de Campo viveram parte de sua trajetória sendo atendidas também pela presente pesquisadora. A delimitação dos participantes da pesquisa consistiu no acompanhamento de dois grupos familiares, com intenção de verificar as conquistas do trabalho realizado sob o enfoque da reinserção familiar, bem como analisar percalços na esfera deste processo. As crianças que participaram da pesquisa também tiveram vivências em situação de rua, visto que esse fator consistiu em um critério importante frente à temática abordada.

Por conseguinte, a escolha da referida instituição para realização da pesquisa deu-se em razão desta apresentar metodologia de trabalho considerada referência ao longo de seus 26 anos de atuação em São Paulo, visando responder às demandas de crianças e jovens acolhidos por meio de estratégias inovadoras, conforme pertinente à demanda familiar, por meio de ações da equipe profissional, continuamente, embasadas no Projeto Político Pedagógico, elaborado com a participação ativa das crianças em diálogo com a equipe.

Esse projeto foi elaborado por meio de referências de especialistas na Educação Integral, como Summerhill School (Neill, 1975), Comunidade Enfance (Cytrynowicz, 2002), Escola da Ponte (2003), Michel Foucault (2008), Donald Winnicott (1984), Edgar Morin (2005), Pichon-Revière (1998) e Paulo Freire (1980) ${ }^{4}$. Sobretudo, o serviço de acolhimento selecionado pautou-se em práticas inclinadas ao acompanhamento familiar estruturado, de forma a adotar planejamento das ações de cuidado com intervenções singularizadas para lidar com as necessidades de cada grupo familiar, inspirando suas práticas na filosofia africana em busca por uma unidade comunitária, solidária e respeitosa cultivada na convivência do espaço institucional, expressada pelo termo Ubuntu que significa: eu sou por aquilo que nós somos.

Em síntese, os autores acima mencionados aprofundam saberes sobre educação democrática; pedagogia da libertação em oposição a lógica da opressão comum no ensino

\footnotetext{
${ }^{4}$ Summerhill, Comunidade Enfance e Escola da Ponte são instituições educacionais e sociais de referência em educação democrática e antiautoritária (Neill, 1975; Cytrynowicz, 2002; Portal Escola da Ponte, 2002).
} 
e nas práticas tradicionais de disciplina infantil. Estes teóricos contribuíram com inspirações para produção do cuidado por meio do vínculo, da análise da dinâmica de grupos, para lidar com conflitos e agressividades de modo ético, afetivo, efetivo e diferenciado no contexto institucional.

A supracitada instituição participou da pesquisa ao contribuir com ricas reflexões e direcionamentos teóricos, sobretudo fornecendo acesso aos prontuários de crianças entrevistadas que não estavam mais acolhidas neste referenciado e admirável serviço de acolhimento. Portanto, as instituições com importantes problemáticas e desafios nas quais transcorreram as entrevistas com profissionais, bem como nas quais foram relatadas as experiências das crianças e familiares no presente do cotidiano do abrigo, não são correspondentes à realidade que vivenciaram neste equipamento que fez parte do passado de suas histórias.

\section{REVISÃO BIBLIOGRÁFICA}

\subsection{A Circulação de Crianças e Adolescentes entre Ruas e Abrigos}

Acessar dados estatísticos sobre o acolhimento institucional oportuniza refletir sobre a dimensão da população de crianças assistidas por essa modalidade de serviço socioassistencial no Brasil, em trânsito entre ruas e equipamentos institucionais. As informações quantitativas podem indicar a relevância do fenômeno do acolhimento de crianças e os desafios dos procedimentos para inserção familiar, a fim de disponibilizar contribuições inclinadas ao aprimoramento das políticas públicas.

As agências internacionais divulgam números astronômicos e imprecisos, apesar dos diagnósticos apontados não estarem dotados de credibilidade, portanto não expressam um panorama confiável acerca da questão, conforme perceptível nos seguintes registros: no mundo afere-se que 150 milhões de crianças e adolescentes vivem em situação de rua (ONU Brasil, 2015), dessas 40 milhões está na América Latina, por vezes, em decorrência da violência doméstica, desastres naturais, conflitos políticos, guerras, etc. 
De forma semelhante, são publicados documentos que sinalizam o contingente de 24 mil crianças que vivem nas ruas do Brasil, conforme levantamento da Pesquisa Censitária Nacional sobre Crianças e Adolescentes em Situação de Rua, demandada pela Secretaria de Direitos Humanos. Destas, $71 \%$ são garotos. Quanto à categoria étnica, $72 \%$ são identificados como negros ou pardos. Os resultados da pesquisa também apontam que apenas $23 \%$ buscam uma instituição de acolhimento, a maioria que recusa tal alternativa destaca que as excessivas regras, com horários inflexíveis e proibição de uso de substâncias estão entre as razões para evitarem abrigos e buscarem a rua como lugar de refúgio, no qual, de maneira ambivalente, acontece a exposição para outras violências e vulnerabilidades (Brasil, 2011).

De acordo com o postulado pelo Instituto de Pesquisa Econômica Aplicada (IPEA, 2003), foi ultrapassado o contingente de 80.000 crianças e adolescentes em acolhimentos institucionais no território brasileiro, enquanto o Levantamento Nacional de Abrigos afirma que dentre os mencionados, 20.000 constam em serviços pertencentes à Rede de Serviço de Ação Continuada (SILVA, 2004). Sendo este dado um ponto de partida e reflexão da pesquisa ao tomar como alvo central a institucionalização e, principalmente, a mediação institucional sinalizada como caminho de resolução à política de reinserção familiar.

Sobretudo, dados mais recentes do Observatório do Terceiro Setor (2018) que divulgou o índice do Conselho Nacional de Justiça de 47 mil crianças e adolescentes acolhidos em instituições no Brasil, em 2018. Estas estimativas devem ser observadas à luz da reflexão crítica de Rosemberg (1993), concluindo-se que na constituição do discurso sobre crianças de rua, há ausência de citação de fontes, de procedimentos realizados para coletas dos dados e de justificativas para os cálculos estabelecidos.

Porém, este esforço de sensibilizar a opinião pública quanto à violência a que são expostas crianças e adolescentes, principalmente de países subdesenvolvidos, gerou uma retórica específica que vem percorrendo o mundo e que, no seu esforço de convencimento, muitas vezes incorpora diagnósticos inverossímeis, distantes da realidade, inadequados enquanto baliza para a ação, além de contribuírem à estigmatização de famílias, crianças e adolescentes em condição de pobreza (ROSEMBERG, 1993, p. 1).

Panter-Brick (2002) aborda a questão das crianças e adolescentes em situação de rua sob a perspectiva correspondente à agenda de Direitos Humanos, ao provocar reflexão sobre a conotação estigmatizante do termo "criança de rua". Bem como alude Gregori (2000): 
Por menino de rua, definiu-se aquele que foi visto quando estava trabalhando em biscates, esmolando, perambulando ou exercendo atividades ilícitas. Além de ser feito à distância, dependendo do olhar do educador, treinado ou não, tal procedimento é duvidoso pela forma como define a quem contar: ele abrange crianças que trabalham nas ruas, mantêm vínculos familiares e frequentam escolas, crianças que moram nas ruas com as famílias e crianças cujos vínculos familiares estão mais esgarçados (MALFITANO \& ADORNO, 2006).

Conforme Adorno e Silva (1999), a circulação pela rua é um referencial de relações sociais estabelecidas distantes das periferias, enquanto recanto de origem desta infância e juventude afetada pela ausência de espaços, de lazer, cultura, desprovidos de lugares protetivos. Essa realidade faz das ruas um ambiente de provar novas experiências de consumo, de relacionamentos, do brincar, embora também seja local marcado pela exclusão social e violação de direitos. Então, neste contexto, é construído o equipamento socioassistencial de acolhimento institucional como modalidade de cuidado à crianças e adolescentes em situação de rua.

Há expressivos números do acolhimento de crianças e adolescentes inclusos nessa forma de medida protetiva, embora, por outro viés, essa opção prevê excepcionalidade e provisoriedade, logo brevidade do período de institucionalização, de acordo com o Estatuto da Criança e do Adolescente (ECA), contudo tais critérios por vezes são inobservados (SIQUEIRA \& DELL'AGLIO, 2006; VASCONCELOS, YUNES, \& GARCIA, 2009).

Avaliou-se que a equipe profissional de acolhimentos institucionais se depara com multíplices impedimentos à concretização da reinserção familiar, o que exibe elementos relevantes a serem verificados, compreendidos e superados, a fim de promover a garantia do direito à convivência familiar e comunitária, enquanto Política Pública.

Para evitar privar as trocas afetivas na família que são responsáveis por imprimir marcas que as pessoas carregam a vida toda, definindo direções no modo de ser e agir com os outros afetivamente. Esse ser com os outros que é aprendido com as pessoas significativas que marcam a história de vida de cada sujeito, prolonga-se por muitos anos e frequentemente projeta-se nas famílias que se formam posteriormente, destacando a relevância da convivência familiar (SZYMANSKI, 2002). 
Há alguns estudos que ressaltam a realidade do delongado período de acolhimento institucional de crianças e adolescentes, ao ocasionar saliente atraso no desenvolvimento integral do sujeito, com intenso prejuízo à aprendizagem e à saúde integral, considerando aspectos psicoemocionais envolvidos. Porém, mesmo em conjunturas nas quais as equipes de profissionais são qualificadas e engajadas na perspectiva da reinserção familiar, ainda persistem certos empecilhos que ficam evidenciados referentes ao processo de retorno ao contexto familiar (OLIVEIRA \& MILNITSKY-SAPIRO, 2007; SILVA, 2004; SIQUEIRA et al., 2011).

Tais entraves consistem em fatores como a insuficiência de engajamento de familiares nas estratégias de suporte parental para fortalecimento de vínculos, bem como a falta de um trabalho construído de modo compartilhado com a família, na busca por reinventar projetos de atendimento que sejam equivalentes às necessidades e singularidades dos grupos familiares. Por vezes, há lacunas concernentes ao alinhamento da rede de proteção quanto às intervenções de cuidado abrangentes à valorização da família extensa e de laços afetivos e sócio comunitários.

Além da adversidade de condições socioeconômicas (AZÔR \& VECTORE, 2008), há até mesmo a crença presente na perspectiva da família que, por vezes, percebe o serviço de acolhimento como ambiente privilegiado para o desenvolvimento e permanência de suas crianças e adolescentes. Diante das vulnerabilidades sociais e desafios vivenciados no cotidiano destes grupos familiares, que os levam a depositar na instituição a possibilidade de proteger seus filhos da escassez.

A exclusão socioeconômica, o abuso de substâncias psicoativas, a fragilidade, perda ou até inexistência de vínculo familiar são fatores importantes para o reforçamento da crença mencionada que pode conduzir famílias e profissionais a buscarem a opção do acolhimento institucional antes de esgotar outros recursos e alternativas de suporte financeiro de programas socioassistenciais ou de apoio para o cuidado das crianças partilhado pela família extensa ou rede comunitária. Deste modo a pobreza ainda é causa de institucionalização da infância e adolescência.

A necessidade de planos de visitas regulares entre acolhidos e seus familiares, bem como da instituição para com as famílias, por intermédio da atuação do corpo técnico de profissionais estão entre os aspectos que perfazem as causas principais de limitações para a reinserção familiar (CAVALCANTE et al., 2010). E, especialmente, a carência de Políticas 
Públicas mais efetivas para lidar com as demandas e desafios que atravessam o processo de reinserção familiar.

Diante de tal panorama, houve constatação de casos mais dificultosos em relação ao retorno familiar e que resultaram no processo de reinstitucionalização de crianças e adolescentes. Contudo, é necessário ampliar os estudos relacionados à análise do fenômeno da reinserção familiar infantojuvenil, considerando aspectos que destaquem potencialidades e fragilidades do processo de acompanhamento familiar pela instituição de acolhimento.

Além dos poucos estudos relacionados a esta questão, destacam-se fatores como o despreparo para realizar um qualificado acompanhamento institucional prévio das famílias, anterior ao desacolhimento ${ }^{5}$, para incidir em uma reinserção familiar bem elaborada. Portanto, é preciso ponderar a respeito das metodologias aplicadas na constituição do processo de reinserção familiar, sob a finalidade de viabilizar uma transição saudável tanto à família, como à criança e adolescente.

Diante da finalidade de minimizar os pontos de fragilidade desse processo que incide em deserções nas rupturas de vínculos familiares posteriores a reinserção familiar, torna-se relevante aprofundar o entendimento da equipe profissional do equipamento de acolhimento sobre as expectativas das crianças e de suas famílias para cooperar com o fortalecimento do vínculo, proporcionando que o processo da reinserção familiar advenha de uma preparação e acompanhamento integral, ao conceder suporte necessário, seja financeiro, ou psicológico, dentre outros, afim de potencializar a reintegração familiar de forma mais consistente e estável.

A medida em que a atuação articulada da rede de serviços socioassistenciais pode favorecer a redução da ocorrência de tais deserções. Por conseguinte, os dados supramencionados apontam para a importância de enriquecer as avaliações e pesquisas neste campo a fim de aperfeiçoar as metodologias de cuidado, as orientações técnicas e profissionais oficiais, bem como as Políticas Públicas do setor em questão.

\footnotetext{
${ }^{5}$ Desacolhimento é o termo técnico utilizado por profissionais do serviço de acolhimento para fazer referência a situação na qual a criança sai da instituição, por conta do processo de inserção familiar ou devido a um projeto de vida com mais autonomia (Resolução Conjunta, 2009).
} 


\subsection{A Rua como Quilombo Contemporâneo}

Figuras 1 e 2. Ritual de formatura utilizado pelos inspetores dos internatos ao objetivar o disciplinamento das crianças. Instituição com sede no Rio de Janeiro em parceria com a antiga Fundação Nacional do Bem-Estar do Menor - FUNABEM. ${ }^{6}$
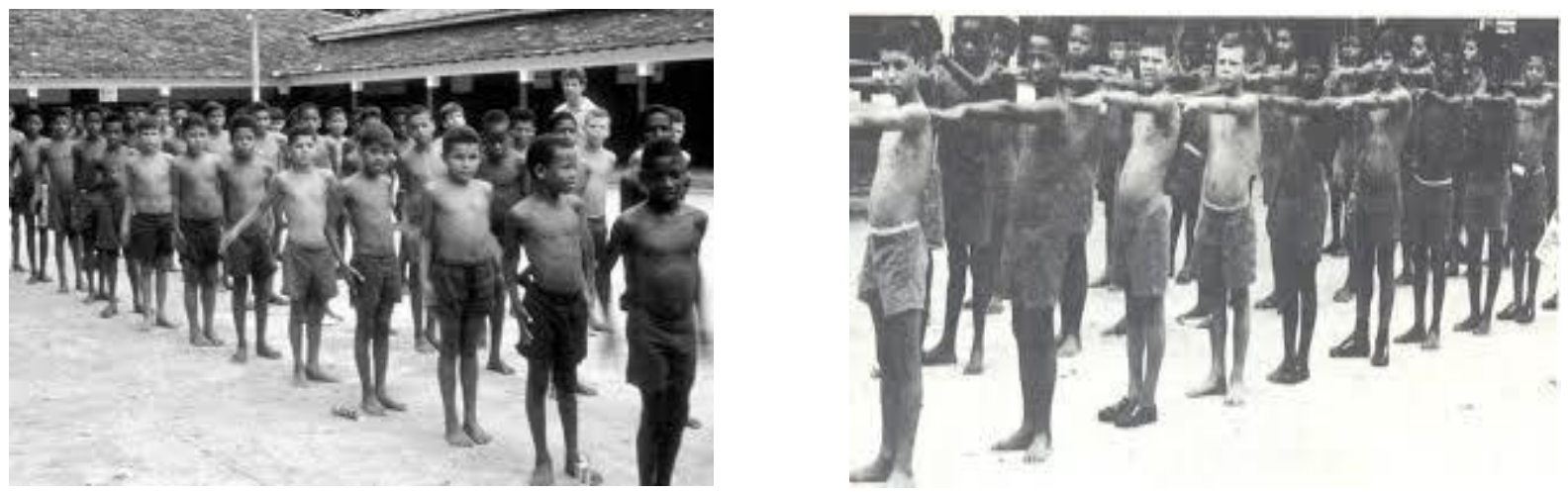

Os processos históricos da institucionalização de crianças e adolescentes possuem ressonâncias relevantes até a atualidade. Conforme os registros de documentos relacionados à trajetória da assistência social infantojuvenil do século XIX ao XX explicita concretamente como crianças nascidas inseridas em famílias com dificuldades socioeconômicas ao buscar suporte estatal para cuidar de sua parentela, eram majoritariamente encaminhadas para instituições, tratadas como órfãs e abandonadas, mesmo não sendo o caso, pois a maioria dessas crianças possuía familiares nucleares ou extensos (RIZZINI \& RIZZINI, 2002).

Múltiplas transformações foram aplicadas no atendimento institucional com as reformulações jurídicas contidas no ECA. Entretanto, há práticas que evidenciam as permanências e heranças que revelam as ressonâncias da história brasileira. Marcada pela cultura institucional que elegeu o modelo asilar como instrumento assistencial para a pobreza associada ao segmento infantojuvenil, tangenciado por políticas públicas de controle social em contexto urbano desenvolvimentista, assim constrói a representação do imaginário de que a população pauperizada perfaz grupo social perigoso, alvo de intervenções do Estado, sob enfoque da higienização da cidade, através da reclusão institucional, isto é, da deserção sociofamiliar.

\footnotetext{
${ }^{6}$ Fonte: RIZZINI, 2004.
} 
O Brasil possui uma longa tradição de internação de crianças e jovens em instituições asilares. Muitos filhos de famílias ricas e dos setores pauperizados da sociedade passaram pela experiência de serem educados longe de suas famílias e comunidades. Desde o período colonial, foram sendo criados no país colégios internos, seminários, asilos, escolas de aprendizes artífices, educandários, reformatórios, dentre outras modalidades institucionais surgidas ao sabor das tendências educacionais e assistenciais de cada época (RIZZINI \& RIZZINI, 2004, p. 22).

Somente durante meados do século passado, a modalidade de internato torna-se obsoleta para filhos de famílias financeiramente confortáveis, ao atingir a inexistência de protótipos institucionais similares. Contudo, tal formato educacional de gestão rígida de tempo e espaço por regras exacerbadas, alicerçadas em relações assimétricas de poder autoritário, por vezes perverso, ainda é sustentado para as camadas populares na contemporaneidade, como forma de controle e coerção aqueles percebidos como ameaças à estabilidade social.

Esta cultura que valoriza a educação da criança realizada por terceiros conduziu as instituições a receberem grupos heterogêneos, segundo determinações étnicas e de gênero. Deste modo, crianças e adolescentes descendentes de índios ou escravos libertos viveram em trânsito por casas de educandos, institutos, colégios internos e asilos.

As adversidades do cotidiano de instituições que hoje refletem os desdobramentos deste cenário histórico, torna compreensível que a rua tenha tornado-se espaço de refúgio e de resistência política às formas de controle social autoritário. Como Marquese (2006) discorre sobre o quilombo enquanto o lugar da busca por proteção, por reinventar uma complexa organização sócio comunitária perpassada pela liberdade, no enfrentamento às dinâmicas provenientes da escravidão. De acordo com Adorno \& Silva (1998, p. 9) "[...] A rua foi e vem sendo espaço à sobrevivência de grupos que acabam sendo excluídos ou se excluem do espaço social da ordem normatizadora. Espaço também dos que saem das instituições, porque o espaço da rua mantém uma relação ambígua com a visibilidade social".

A rua é o lugar no qual a autenticidade e a pluralidade dos modos de existir e viver encontram meios de expressão expandidos, não delimitados por regras rígidas comuns em instituições de acolhimento ou mesmo na residência de tantas famílias. Assim como o lugar histórico do quilombo retratou o lócus de refúgio e proteção, também de árdua conquista política voltada à conservação da história e da cultura africana. Logo, é possível 
compreender o fenômeno contemporâneo da rua ter se tornado ambiente de refúgio, lar de resistência e luta política no confronto aos mecanismos de controle social e coerção autoritária.

O quilombo e a rua retratam uma dimensão sociopolítica violentada, perseguida, de semelhante maneira como a cultura africana sofre tentativas de apagamentos de suas expressões. A rua como quilombo atualizado é o contexto que manifesta o confronto contra as questões da desigualdade étnica, do estigma e do preconceito social em torno do racismo, por meio da busca pela conquista de escolher como ser e viver pautando-se na preservação cultural das africanidades.

\subsection{Ciranda entre famílias e redes de afeto}

A rede de acolhimento institucional de crianças muitas vezes atua com engajamento voltado à adoção judicial como meio para inserção familiar, inclusive em casos em que não houve o devido trabalho de busca ativa para contatar a família nuclear ou extensa, assim a fim de investir no fortalecimento de vínculos para esgotar outras possibilidades de redes de afeto, até mesmo extrafamiliares, antes de cogitar o rumo da adoção.

A temática do acolhimento de crianças e adolescentes, contudo, envolve considerar outras formas não institucionalizadas de cuidado que acontecem por meio da circulação de crianças, conforme nomeou Fonseca (1995). Circulação essa que perfaz passagens com características similares a da adoção, contudo não judicializada, mas sim informal, por meio da trama das redes de relações sociais.

Para os moradores da vila de Porto Alegre com quem Fonseca trabalhou, esta circulação de crianças se dá, na maior parte das vezes, entre familiares com vínculo consanguíneo ou pessoas pertencentes à família extensa. Mais raramente, a prática inclui vizinhos e amigos que acolhem essas crianças e adolescentes em seus lares, por parte significativa da sua infância ou adolescência (FONSECA, 1995).

Desde os primeiros dias do meu trabalho em bairros populares de Porto Alegre, me impressionou a incidência extraordinariamente alta do que acabei rotulando, segundo a convenção antropológica como, de "circulação 
de crianças", ou seja, o grande número de crianças que passa parte da infância ou juventude em casas que não a de seus genitores. $O$ estudo de uma vila de invasão, composta de mendigos e trabalhadores braçais, desempregados na maioria, revelou que mais da metade das mães tinham em algum momento dado o seu filho para criação. Outro estudo, desta vez sobre uma área residencial de classe trabalhadora mais sólida, revelou que mais da metade das mulheres adultas, em um momento ou outro, recebeu uma criança de outrem para criar (FONSECA, 1995, p.13).

É importante observar que o mesmo fenômeno foi percebido como processo social corriqueiro na dinâmica da interação nos distintos bairros mencionados, o que indica a necessidade de desconstruir a ideia estigmatizada de que o fenômeno da circulação de crianças e adolescentes é sinal de família desorganizada ou desestruturada. Talvez a questão seja retirar as lentes do preconceito para observar outros arranjos de jeitos de viver e de organização que também são perpassadas por afeto e cuidado.

A partir das minhas experiências em bairros periféricos de Porto Alegre, montei diversas hipóteses: que a unidade significativa da organização social é a família extensa; que essa família extensa prioriza laços consanguíneos à relação conjugal; e que a circulação de crianças entre diferentes mães de criação faz, historicamente, parte da dinâmica familiar destes grupos (FONSECA, 1995, p.22).

Torna-se fundamental considerar a questão da infância e adolescência entre as diversidades de seus modos de vida, ao observar o fenômeno da criança em situação de rua não como problema isolado, mas como processo inserido em circunstâncias específicas. Os próprios termos utilizados até a atualidade para referir-se a tal público já denunciam aspectos importantes destes processos históricos e socioculturais, nos quais essa população foi classificada como "menino de rua", "menor infrator", "criança abandonada", "usuário de droga". Tais termos carregam forte conotação de criminalização, estigma social do pobre, além de conferir significado de patologização às famílias que seriam consideradas desestruturadas, psicologicamente fragilizadas e despotencializadas.

A desconstrução dos estereótipos e preconceitos edificados sobre as famílias aqui estudadas, permite realizar abertura para questionar padrões socialmente aceitos e legitimados da configuração familiar idealizada, para poder compreender a diversidade dos 
modos de vida, de subjetivação, de estruturas e organizações familiares que transcendem ao enquadramento que visa a normatização das formas de ser e estar nas relações.

Observando a prática da circulação de crianças como uma estrutura básica da organização de parentesco em grupos brasileiros de baixa renda, nossas atenções se deslocam de um "problema social" para um processo social, e nosso enfoque analítico muda de "o colapso dos valores tradicionais" para formas alternativas de organização vinculadas a uma cultura popular urbana (FONSECA, 1995, p.16).

Diante da urbanização construída de forma a demarcar a territorialização das fronteiras econômicas, dos espaços de residências de alto luxo, separados das comunidades periféricas tocadas pela escassez material, as posições e expressões das classes abastadas são hipervalorizadas, enquanto, antagonicamente, as das classes populares são desvalorizadas. Isto se reflete na depreciação social da pluralidade das maneiras de ser no mundo, emergidas do imperativo de enfrentar as adversidades da vida com os recursos e dispositivos disponíveis, de acordo com o contexto histórico e econômico dos grupos sociais.

Não obstante, é cabível reforçar a imprescindibilidade de não sermos capturados pela percepção advinda do determinismo econômico que naturaliza a pobreza como exclusiva causadora de circulação de crianças, considerada de forma reducionista como aberração social ou mesmo consequência de falha moral de famílias que abandonam seus descendentes. A concepção de abandono não é aceitável na criteriosa análise da pesquisadora supracitada, que evidenciou o quanto a prática de circulação de crianças e adolescentes incide em meio de promover cuidado e acolhimento para estes grupos.

A problematização das contingências existenciais de pessoas pertencentes ao segmento econômico popular, portanto, não consiste em romantizar a pobreza ou torná-la esteticamente mais agradável, todavia, o interesse de tal reflexão consiste em abranger o entendimento do fato de que a pobreza em si não é categoria sociológica suficiente para analisador e abarcar a complexidade do fenômeno cultural, sustentado por mais de 10 gerações, da circulação de jovens e crianças. Inclusive, neste semelhante sentido reside a necessidade de valorar o caleidoscópio de modos de viver, logo, não significa deixar de militar por equidade social e pela erradicação da pobreza. 


\subsection{Contribuições Antropológicas e Concepções de Família}

Buscar compreender o sistema de significados culturais, crenças e valores de crianças que viveram nas ruas, nos serviços de acolhimento, e de suas famílias de origem pode proporcionar acesso à história pela perspectiva que possuem para as vivências e relações tanto familiares quanto institucionais, para então possibilitar ouvir narrativas das maneiras como conceituam família. Deste modo, alguns estudos antropológicos enriquecem a discussão de tal temática.

No século XIX, a ciência antropológica era fortemente identificada com o pensamento evolucionista, em conformidade com as demais correntes científicas da época, influenciadas pela lógica hegemônica que distinguia as civilizações entre povos "primitivos" ou "civilizados". Entretanto, certos pesquisadores, incomodados com os impactos de tal fabricação intelectual, investiram em construir um etnocentrismo inspirados nas postulações de Rousseau, ao afirmar que os povos primitivos eram ética e moralmente superiores e romantizar povos intitulados como "bons selvagens" (FONSECA, 1995).

Diante deste cenário, os recentes esforços da Antropologia têm sido desconstruir ambas as formas de pensamento pelas razões estigmatizantes e estereotipadas da forma revelada na primeira, bem como pelo romantismo idealizado da segunda. Para isso, o caminho da metodologia antropológica fora crucial, por buscar apreender o sistema simbólico que sustenta a lógica do outro. Mas, para alcançar este objetivo, é primordial reconhecer o sistema simbólico que estrutura nossa lógica é somente um dentre incontáveis e diversos outros e que não são passíveis de serem estigmatizados como bom ou mal ou hierarquizados como superior ou inferior, mas apenas como distintos sistemas simbólicos.

Ao seguir esta reflexão, podemos encontrar problemas em outros termos, mais associados às crianças e adolescentes em situação de vulnerabilidade social, como "menor", "carente", "infrator", "moleque de rua", pois esses verbetes são rótulos que produzem a objetificação da infância e juventude do pobre. Além disso, há outras maneiras de reificar e fazer o preconceito operar de forma mais encoberta através de concepções com teor pejorativo menos evidente, como o binômio "casa-rua"; enquanto casa carrega semântica positiva, de segurança, de lugar da família, a palavra rua está atrelada à representação restringida ao perigo e ao lugar de abandono. 
Mas será que essas categorias sempre correspondem às representações citadas? Ao observarmos a multiplicidade dos jeitos de produção de vida nas ruas possui interfaces de lugar de proteção, de lugar de família onde está o "pai de rua", a "mãe de rua" que se tornam padrinhos afetivos; é o espaço onde crianças e adolescentes encontram esconderijo para as violências inúmeras que, por vezes, sofreram no interior de suas casas.

Então, é fundamental refletir acerca da noção de família e sua construção histórica e social. Deste modo, a representação presente no imaginário social a respeito da concepção de família equivale à noção de família conjugal configurada pela residência compartilhada entre um casal e seus filhos. Neste cenário, a casa é um ambiente voltado para mulheres e crianças, enquanto as ruas e locais públicos são ocupados por homens. Apesar da naturalização deste modelo familiar como espontâneo, Fonseca lembra que:

\begin{abstract}
Esquecemos que esse modelo emergiu no bojo de um contexto específico, por volta do século XVIII, que teria sido impossível ele se consolidar sem certos elementos históricos - a centralização do Estado, por exemplo, e a individualização dos salários. Em um processo de enclausuramento progressivo, essa família se retirou da rede extensa da parentela e compartimentalizou os espaços de seus membros, tornando a rua fora do âmbito de mulheres e crianças. As medidas coercitivas de enclausuramento dos séculos XVIII e XIX visavam sanear a rua, retirando mendigos, "órfãos" e prostitutas dos espaços públicos (FONSECA, 1995, p. 20-21).
\end{abstract}

O termo "órfão" é problemático devido ao fato de que praticamente inexistem crianças e adolescentes absolutamente órfãos, isto é, sem nenhum parente vivo. Em diversos casos de crianças institucionalizadas, ao realizar busca ativa de seus familiares, são encontradas pessoas com algum grau de parentesco, ainda que oriundo de sua família extensa ou de rede de relacionamentos comunitários significativos que podem operar como família a partir de uma concepção ampliada do significado do termo.

Ao retomar a reflexão sobre a construção da família conjugal idealizada no imaginário social, é imperativo considerarmos que o uso do conceito de família foi marcado por uma perspectiva evolucionista. Assim como a família conjugal, foi uma fabricação resultante de aspectos históricos, econômicos, culturais que produziram um jeito a mais de ser família dentre tantos outros modos de sê-lo, podendo ser reformulado, sem por isso ser superior ou inferior, mais ou menos saudável psicologicamente. Estas são, portanto, avaliações 
descabidas, pois as vicissitudes familiares representam apenas configurações diferentes e o que passa disso são elucubrações permeadas pelo preconceito latente ou explícito, posto que as concepções de família podem ter significados fluídos e complexos de acordo com a vivência de cada sujeito.

A metodologia antropológica conduz o pesquisador a abrir mão de suas ideias préconcebidas ao adentrar nos lugares da investigação de campo, pois, apesar de preparar-se com embasamento teórico, seus conceitos não devem impor obstáculos para aquilo que a realidade do campo apresentará em sua singularidade. Contudo, o pesquisador deve ter ciência de que a realidade encontrada no campo consiste em um material científico que concede somente verdades relativas, ou seja, hipóteses que não são rígidas, pois são modificadas a partir de cada confronto com a realidade e suas distintas interfaces. Portanto, a cada vivência, o pesquisador deve elaborar uma inédita avaliação.

\subsection{Processos históricos dos filhos do Estado, da mídia e da família}

A teoria evolucionária apresenta protocolos sociais de obrigações de cuidados da família para manutenção da confiança do bando para sobrevivência gregária na gênese da história humana. Durante a pré-história não havia família, nem na Idade Média, assim como ter reconhecimento de paternidade não era um acontecimento comum. A história evolucionista descreve que os vínculos afetivos e as obrigações sociais das mães consistia em cuidarem dos filhos para serem aceitas no bando, assim como o pai tinha papel de defender os filhos de ataques ao bando, pois se não fizesse, seria encarado como covarde e sofreria consequências punitivas impostas pelo bando, até mesmo através da exclusão do grupo (ARIÈS, 1981).

A proteção aos filhotes enquanto estes são dependentes dos genitores é um fenômeno característico em várias espécies, mas manter vínculo permanente entre progenitores e filhos é uma ideia recente da história humana. A família como a conhecemos na atualidade têm cerca de 300, 400 anos de história. A taxa de mortalidade infantil era dantesca, portanto, não era comum se vincular tanto aos filhos, visto que o distanciamento afetivo oferecia resiliência para não entrar em crise por conta do luto. Então, ao evitar o enlutamento, por conseguinte, haveria condições propícias para cuidar dos filhos sobreviventes (ARIÈS, 1981). 
A família é a instituição de estrutura social basilar à formação humana, sendo um núcleo de poder externo ao Estado. As famílias existem por uma necessidade biológica, pois um bebê sem contar com os cuidados de sua família, certamente, não sobrevive. Perante a perspectiva do evolucionismo social, uma família que cuida de seus filhos sobrevive e evolui, enquanto o oposto também é verdadeiro, isto é a falta de cuidado poderia causar a extinção de gerações.

A relação entre familiares depois de tal época assume características funcionais, voltadas à formação do filho legítimo que será responsável por cuidar da herança familiar. Sendo que os laços de amor são construídos após o período do Romantismo, no século XVIII quando há registros históricos de pinturas artísticas de mães olhando para os filhos com amor. Estima-se que a partir de então o modelo de amor materno passa a ser inventado e tornase uma realidade fortalecida na cultura. A habilidade biológica de gerar filhos é mais comum e fortalecida ao longo da história que a habilidade de exercer funções parentais materna ou paterna com longevidade (ARIÈS, 1981).

O conceito de amor materno é desmistificado pela reflexão sobre o sentimento de sofrimento e o peso emocional interligado à vivência da maternidade, segundo a autora (BADINTER, 1985) não existe nada mais inconfessável em nossa sociedade do que a verbalização levantada por parte da mãe de que se equivocou ao notar que não era possui desejo ou habilidades para a ser mãe. Tal declaração faz a mulher ser vista como um tipo de monstro social. A autora discorre sobre as insatisfações atreladas à maternidade e desconstrói a noção naturalizada de instinto materno, para enfocar nos aspectos sociológicos e culturais que tornam a maternidade uma experiência turbulenta para muitas mulheres ao longo da história.

O vínculo afetivo contribui para o engajamento do grupo familiar nas práticas de cuidado focadas na sobrevivência de sua organização social. Portanto, há dimensões distintas da formação da família: biológica, social e histórica, uma dessas dimensões é estabelecida pela mídia, por meio da propaganda e do marketing, dentre demais conteúdos disseminados que sugestionam o ideal de 'família de comercial de margarina' a ser perseguido, isto é, configuração formada por pai, mãe e filhos retratados como possuindo convívio amoroso, feliz e desprovido de conflitos.

Enquanto os dados do Instituto Brasileiro de Geografia e Estatística elucidam que a configuração de família na contemporaneidade é plural, formada por configurações 
diversificadas que fizeram declinar o modelo tradicional de família, ao ponto que famílias monoparentais femininas ou masculinas terem se tornado mais numerosas, assim como famílias matriarcais, isto é, chefiadas por mulheres também tem progredido nos percentuais estudados por Jociles e Moncó (2010).

A socialização e o desenvolvimento das identidades na atualidade são transversalizados por influências da família e de instâncias tradicionais da educação, por intermédio de instituições estatais voltadas ao processo educacional, deste modo tanto a escola quanto o equipamento de acolhimento são ambientes regidos pelo Estado com responsabilidades educacionais que impactam o processo de formação social das pessoas (SETTON, 2002). Estas instâncias perfazem uma rede heterogênea que possui relação de interdependência no impacto sobre o desenvolvimento humano.

A mídia também consiste em uma instância educacional articulada com as demais instituições pedagógicas supracitadas que estão envolvidas na sociedade presente e contribuem para instauração de um espaço pluralizado de códigos e influências identitárias. Neste período histórico os sujeitos constroem sistemas de referências para elaborar sua identidade extraindo inspirações da mídia, família, escola, entre demais instituições inclinadas ao processo educativo, como serviço de acolhimento.

A circulação da informação e a dinâmica de produção da cultura de massa possui função relevante na constituição psicocognitiva dos valores e da moral das famílias. Consiste em uma nova ordem social influenciada pela abrangente heterogeneidade do universo cultural. Particularmente, no Brasil desde 1970 o convívio social com os meios de comunicação tornou-se capilarizado e abrangente, contribuindo para o aprofundamento da cultura de massa (SETTON, 2002). Deste modo, é possível observar como a trajetória da história concedeu a sociedade o lugar de filha do Estado, da família e da mídia, visto que todas essas instâncias são providas de papel constitutivo na formação da identidade dos sujeitos. 
3.6 Estado herói versus família algoz: Repercussões de nomenclaturas na cultura institucional

O Estado ousa subtrair do pouco que as crianças possuem (Khattar, 2019).

A instituição de acolhimento possui aspectos legais e formais em sua caracterização enquanto serviço que presta abrigamento em caráter provisório e excepcional para crianças e jovens de ambos os sexos, com margem etária entre 0 e 17 anos e 11 meses de idade. $O$ público é atendido como medida de proteção integral diante da condição de vulnerabilidade socioeconômica (CNAS/CONANDA, 2009).

As diretrizes legais regulamentam que o ambiente da instituição deve ser aconchegante como uma casa de família, e deve ser situada próxima a comunidade de origem da pessoa acolhida. $\mathrm{O}$ acolhimento deve ser realizado em pequenos grupos (20 vagas expansíveis até 22 vagas na Operação de Baixas Temperaturas), deve beneficiar o convívio familiar e comunitário, e ter funcionamento ininterrupto (24 horas por dia). Grupos com qualquer grau de parentesco não devem ser separados em equipamentos distintos (CNAS/CONANDA, 2009). O serviço deverá ser concedido até oportunizar a reintegração familiar ou a destinação à família substituta.

A maneira de ingresso ao abrigo acontece via determinação judicial ou por intermédio do requerimento do Conselho Tutelar diante de situações de violação de direitos como negligência, abandono e demais violências. Sendo que cada instituição atua em local alugado, concedido ou próprio, e é administrado por organizações filantrópicas proibidas de utilizar placas em sua faixada, decorrente da importância do sigilo de sua natureza institucional com finalidade de garantir o anonimato da identidade do público atendido (CNAS/CONANDA, 2009).

A reflexão acerca dos desdobramentos do presente capítulo teve seu início durante o intercâmbio acadêmico em Portugal, cenário de contrastes com a realidade brasileira no concernente aos recursos materiais e financeiros abundantes. Nas instituições visitadas haviam cômodos que serviam de estoques para moveis, eletrodomésticos, brinquedos, alimentos, roupas, dentre demais itens que excediam ao necessário para os utilização nos serviços. Apesar de tal contrate, também haviam semelhanças nas dinâmicas de práticas 
técnicas da equipe com viés da medicalização da infância, diante de comportamentos considerados inadequados ou agressivos.

Ao focar em uma reflexão comparativa sobre contrastes expressados nas terminologias brasileiras e portuguesas empregadas em suas respectivas políticas da assistência social voltada para o acolhimento, bem como nomenclaturas oficiais provenientes dos diferentes setores da rede de serviços de ambos os países.

No Brasil, quando a criança ou adolescente está em situação de violência ou negligência que justifique a razão do acolhimento, utiliza-se o termo "denúncia" para o ato de acionar instituições responsáveis pelo cuidado da infância e adolescência. Denúncia consiste em nomenclatura deveras policialesca e a sua origem etimológica advém da esfera da segurança pública, do âmbito da criminologia, "do mesmo étimo de anunciar, designando em geral o ato de atribuir responsabilidade criminal a alguém".

Denunciar: 1 Ato ou efeito de denunciar; revelação. 2 Revelação de algo ilegal que era secreto: "Recebemos uma denúncia. Importa-se se revistarmos seu quarto? [...] - Que denúncia? - Tráfico de drogas" (LA3). 3 Acusação de crime ou de qualquer atitude ilegal feita a uma autoridade. 4 JUR Exposição escrita que revela o autor de uma ação criminosa e solicita ao juiz criminal pena prescrita em lei; denunciação. 5 Exposição pela qual uma das partes de um contrato comunica à outra a intenção de rescindi-lo e o prazo para a sua realização (MICHAELIS, 2019).

As instituições de Portugal correlatas à área da defesa da infância possuem atribuições equivalentes às brasileiras supramencionadas, porém, elegeram termo intensamente distinto e salientemente mais apropriado para o campo do cuidado, em consonância com o papel de atuação do serviço assistencial em questão. O termo empregado em Portugal é "sinalizar". Portanto, se há uma criança ou adolescente em situação de vulnerabilidade que necessite ser direcionado para o acolhimento institucional, recomenda-se à população que sinalize aos órgãos competentes para condução da situação às providências para devida proteção da criança (TORRES; PEGADO et al., 2008).

Sinalizar: 1 Exercer as funções de sinaleiro. 2 Pôr sinais em lugares determinados para indicar o rumo aos transeuntes, motoristas etc.; pôr 
sinalização em. 3 Comunicar através de sinais. 4 FIG Tornar evidente; assinalar, marcar (MICHAELIS, 2019).

O Conselho Tutelar, equipamento da proteção da infância no Brasil, tem como uma de suas funções receber as denúncias de maus tratos e realizar encaminhamentos para as possibilidades de fluxo institucional de defesa infantojuvenil. Contudo, embora o papel desse serviço seja de promoção de cuidado, a concepção predominante entre a população corresponde a percebê-lo como órgão punitivo e coercitivo. Narrativas de crianças institucionalizadas trazem a conotação do Conselho Tutelar como aquele responsável por levar a criança para o abrigo, como penalidade por não ter sido obediente e dócil na casa de sua família.

A autora Medaetes (2015, p. 316) pôde observar semelhante realidade em sua pesquisa com famílias na região de Tapajós, no Pará; e Moura (2012, p.107) no contexto de instituições de cuidado e da área da justiça que, por vezes, revitimizam as crianças atendidas. Assim como na representação e narrativa de adultos familiares de crianças acolhidas, o Conselho Tutelar consiste na instituição que pune os pais que não cuidam devidamente dos filhos, ao privá-los do convívio com os mesmos por meio do acolhimento.

As narrativas registradas acima são relatos recorrentes ao longo da trajetória profissional da autora da presente pesquisa, desde o Projeto Quixote até as instituições de acolhimento. As concepções manifestas no discurso de crianças, adolescentes e seus familiares no campo da presente pesquisa está em concordância com o suprareferido. Deste modo, para os filhos o Conselho Tutelar era possuía papel equivalente ao do "Homem do Saco"[3] que sequestra as crianças indisciplinadas. Enquanto para a família, o mesmo era um braço da polícia, voltada a punir parentes que não tinham como dar o melhor para seus filhos, nos mais abrangentes sentidos, inclusive financeiro.

O termo 'tutelar' tem sua origem no contexto jurídico, portanto está distante do cotidiano popular, o que abre margem para interpretações imprecisas e temerosas a respeito da possibilidade da instituição avaliar se há razão suficiente para que a criança ou adolescente em situação de risco social fique sob a tutela do Estado por meio da institucionalização no abrigo.

Tutela: 1 Encargo jurídico conferido a alguém, por lei ou testamento, de velar por administrar os bens e representar civilmente um menor, um 
interdito ou pessoa desaparecida; tutoria. $2 \mathrm{~A}$ autoridade legal para exercer esse encargo. 3 Ação de proteger, vigiar ou defender alguém ou algo mais fraco ou frágil. 4 Sujeição vexatória; dependência. Tutela cautelar, aquela que visa proteger direitos que estejam eminentemente ameaçados. 5 Tutela dativa, aquela conferida por juiz, quando não houver tutor testamentário ou legítimo. 6 Tutela jurídica, aquela assumida pelo Estado e exercida por juízes, evocando para si o dever de solucionar pendências, conforme as normas gerais e institucionais (MICHAELIS, 2019).

Ao visitar instituições em Portugal, a autora teve a oportunidade de conhecer a Comissão de Proteção dos Direitos da Criança e do Adolescente, serviço responsável por receber as sinalizações a respeito das crianças em situação de risco, e fazer os encaminhamentos necessários, portanto possui papel muito semelhante ao do Conselho Tutelar brasileiro. Todavia, a nomenclatura do órgão traz termos mais acessíveis ao cotidiano da sociedade, pois não utiliza termos demasiadamente técnicos, tampouco do juridiquês ${ }^{7}$, pelo contrário, transmite com clareza o objetivo da instituição de cuidado ao público infantojuvenil.

Comissão: Reunião de pessoas designadas por uma assembleia para realizar uma tarefa. Proteção: 1 Ato ou efeito de proteger(-se); adarga. 2 Ato de proteger alguém ou algo de um perigo, de um mal etc.: Depois de receber ameaças, solicitou a proteção da polícia. 3 Auxílio para o que é mais fraco ou menor: Os pequenos negociantes tiveram a proteção do governo. 4 Cuidado ou assistência especial dispensados a alguém: "Esse tal advogado, logo que chegou do Norte, [...] procurou-me, dizendo-se meu sobrinho, filho de uma irmã, a quem não vejo desde quarenta anos. Pediu-me proteção e eu the pedi provas" (LB1). 5 Auxílio de ordem moral ou material, concedido por um indivíduo, um grupo etc.; patronagem. 6 Abrigo contra os rigores do tempo; resguardo: Durante o temporal, procurou a proteção de uma marquise (MICHAELIS, 2019).

Eleger a palavra "proteção" no texto da política pública nacional implica em enfatizar a noção de cuidado, de promoção de defesa, segurança às crianças e adolescentes. Logo, não traz consigo nenhum significado atrelado ao viés policialesco. Já o emprego do termo 'direitos' evidencia a escolha por destacar a responsabilidade compartilhada pela tríade Estado, sociedade e família de zelar pela infância e adolescência. Enquanto falar apenas

\footnotetext{
${ }^{7}$ Juridiquês: neologismo para designar o uso dispensável e exacerbado do jargão técnico e jurídico do Direito.
} 
em "tutela", denota uma responsabilização da família, portanto, a família fica no lugar simbólico do algoz no discurso, enquanto o Estado fica no espaço simbólico do herói.

Os termos escolhidos revelam muito das vivências históricas e construções contemporâneas de ambas nações, pois nomear é designar, é atribuir qualificação, propósito e função. A escolha cautelosa dos termos também pode influir na efetividade do funcionamento do serviço, pois se transmite significados policialescos, pode provocar receio na sociedade, ao invés de fomentar engajamento de corresponsabilidade no cuidado às crianças em parceria entre sociedade e Estado.

No Brasil, a cultura de violência institucional reproduz traumas e sofrimentos às crianças e adolescentes protagonizados pela Assistência Social e pelo Conselho Tutelar desprovido de qualificação a altura da complexidade demandada, além da ação policial de truculência voltada aos que estão em situação de rua, indiscriminadamente, onde nem mesmo as crianças saem ilesas, etc.

Tais questões perfazem problemáticas que permitem questionar e aproximar-se de algumas conclusões sobre o quanto os termos que privilegiamos para nomear nossas políticas públicas do dia a dia trazem repercussões na cultura construída nas intervenções abusivas adotadas por órgãos intersetoriais da proteção infantojuvenil brasileira.

As atuações violentas por parte de agentes da segurança pública contra crianças e adolescentes também revelam as raízes culturais da violência estatal. Os números de homicídios da juventude negra brasileira em mortes causadas por policiais mostram dados alarmantes sobre a violência estatal no campo da adolescência (Adorno et al., 2018).

A publicação em noticiários sobre ocorrências de agressões policiais voltadas para crianças evidência o quanto essa realidade é frequente no cenário de solo verde e amarelo. Em ambos os casos, a impunidade é recorrente, o que potencializa a naturalização e o silenciamento desses crimes tão graves (Fórum, 2017).

O Atlas da Violência (2018) constatou que a prevalência de homicídio em crianças e jovens negros $(40,2 \%)$ foi duas vezes e meia superior ao de não negros (16\%), do total de 33.590 mortes de crianças e jovens no Brasil referente ao ano de 2016. A tabela a seguir mostra dados da região periférica da zona leste de São Paulo, referente a incidência de homicídios, 
por lesões com armas de fogo ou outras formas de violências, inclusive traz a dimensão pouco estudada da violência exercida e legitimada pelo Estado através da polícia, conforme consta na ilustração que calcula os casos de 'intervenção legal'.

Figura 3. Homicídios segundo agente de agressão e faixa etária no subdistrito de Capão Redondo de $2010-2015^{8}$

\begin{tabular}{|c|c|c|c|c|c|c|c|c|}
\hline \multirow[t]{2}{*}{ HOMICÍDIOS } & \multicolumn{2}{|c|}{$\begin{array}{c}\text { AGRESSÃO } \\
\text { (ARMA DE FOGO) }\end{array}$} & \multicolumn{2}{|c|}{$\begin{array}{c}\text { AGRESSĀO } \\
\text { (OUTROS) }\end{array}$} & \multicolumn{2}{|c|}{$\begin{array}{l}\text { INTERVENÇĀO } \\
\text { LEGAL }\end{array}$} & \multicolumn{2}{|c|}{$\begin{array}{l}\text { TOTAL } \\
\text { GERAL }\end{array}$} \\
\hline & $\mathbf{N}$ & $\%$ & $\mathbf{N}$ & $\%$ & $\mathbf{N}$ & $\%$ & $\mathbf{N}$ & $\%$ \\
\hline 12 a 15 anos & 20 & $14,3 \%$ & 3 & $10,4 \%$ & 1 & $5,6 \%$ & 24 & $12,6 \%$ \\
\hline 17 a 18 anos & 25 & $17,9 \%$ & 7 & $21,9 \%$ & 5 & $27,8 \%$ & 37 & $19,5 \%$ \\
\hline 19 a 24 anos & 62 & $44,3 \%$ & 11 & $34,4 \%$ & 8 & $44,4 \%$ & 81 & $42,6 \%$ \\
\hline 25 a 29 anos & 33 & $23,9 \%$ & 11 & $34,4 \%$ & 4 & $22,2 \%$ & 48 & $25,3 \%$ \\
\hline Total Geral & 140 & $100 \%$ & 32 & $100 \%$ & 18 & $100 \%$ & 190 & $100 \%$ \\
\hline
\end{tabular}

Parte das crianças e famílias que contribuíram com o presente trabalho também possuem esta percepção acerca do Estado como violento em suas instituições, não somente de segurança, mas também de assistência, por conta da atuação policialesca de equipamentos do cuidado socioassistencial.

No Diário de Campo será explicitado como uma jovem foi criminalizada pela instituição de acolhimento, de forma recorrente, quando a equipe a conduzia a delegacia para registrar Boletim de Ocorrência contra ela, por causa de situações que poderiam ser tratadas pelo viés educacional da mediação de conflitos e conciliador da justiça restaurativa.

A respeito de cenário do acolhimento em Portugal, existe aproximadamente 8 mil crianças institucionalizadas. Nação que corresponde à metade do estado de São Paulo em termos populacionais, sua dimensão demográfica é vantajosa para promover a efetividade das Políticas Públicas, já que a realidade é de menor complexidade do que numa nação tão populosa quanto a brasileira.

\footnotetext{
${ }^{8}$ Fonte: SIM/SES/PMSP, 2016 - Serviço de Informações de Mortalidade da Secretaria de Saúde do Município de São Paulo.
} 
Logo, por ínfimo período de tempo, crianças ficam em situação de rua ou em condição de sem abrigo, como preferem nomear em Portugal. O pequeno tempo de exposição infantil à vulnerabilidade de viver em situação de rua deve-se à celeridade do acolhimento da sua rede socioassistencial. Também há aquelas crianças acolhidas decorrente da prisão de seus pais, ou perda dos pais devido a acidentes.

Em Portugal existem programas de adoção e de acolhimento subdivididos do seguinte modo:

I- Lares de Acolhimento: serviço institucional e residencial;

II- Famílias de Acolhimento: onde as crianças são cuidadas por até seis meses por cada família de acolhimento e não podem ser adotadas por essas. São avaliados pela Segurança Social;

III- Aldeias SOS: surgiu como alternativa para acolher crianças vítimas da guerra, que perderam seus pais devido à violência da guerra. Há três em Portugal.

IV- Casas do Gaiato: instituição privada de acolhimento infantojuvenil;

V- Centro educativo para adolescentes em conflito com a lei: instituição semelhante a proposta da Fundação Casa, com possibilidades de institucionalização em regime fechado (escola interna) ou em regime aberto (escola comum), conforme determinação jurídica. Sendo que em Portugal a maioridade penal incide a partir dos 16 anos de idade;

VI- Aldeia SOS: em cada casa tem uma 'Mãe SOS'. Há 819 crianças e adolescentes contemplados por esse modelo de acolhimento, sendo que em cada casa moram cerca de 8 crianças. Tem um chefe da aldeia, que corresponde a uma figura masculina, mas não é chamado de 'Pai SOS'.

A modalidade vigente nos Lares de Acolhimento é destinada ao trabalho do processo de reinserção familiar, enquanto as demais instituições trabalham com a perspectiva da adoção ou do desenvolvimento da autonomia da criança após serem esgotadas as possibilidades de adoção, ao atingir idade mais avançada. 


\subsection{Sexualidade de Crianças e Adolescentes na Instituição de Acolhimento}

Dentre os maiores tabus sociais encontra-se a temática da sexualidade, assunto polêmico, sobretudo nas reflexões sobre os desdobramentos das expressões da sexualidade no desenvolvimento da criança e do adolescente. A complexidade do assunto pode ser maximizada quando a equipe profissional do serviço de acolhimento depara-se com a realidade do desenvolvimento da sexualidade na infância e adolescência do público atendido, com manifestações que demandam conhecimento de como lidar e conduzir situações, apesar da ausência de uma diretriz oficial que possa servir de referência teórica e técnica (MELO, 2010).

A carência de tal normativa torna imperativa a necessidade de dialogar em rede com os setores do cuidado da infância e da adolescência para construir e elaborar diretrizes aplicáveis ao cenário do serviço de acolhimento, com o objetivo de produzir práticas inspiradas nos conhecimentos internacionais mais robustos neste campo, para refletir sobre as experiências históricas, sem desconsiderar as peculiaridades brasileiras. Deste modo seria oportuno construir e propiciar práticas norteadas por saberes decorrentes de engajamento coletivo frente a este tema.

A comunicação articulada entre atores do sistema de garantia de diretos voltada a pensar em ações de educação sexual infantil e direcionada ao adolescente no contexto do acolhimento, a fim de informar, dialogar e proteger as crianças de violências, de forma lúdica e leve, apropriada ao nível de linguagem do público acolhido. Abordando a sexualidade como governo de si e expressão de cuidado, assim como na ótica foucaultiana (FOUCAULT, 1988).

A educação sexual deve ser mais que fornecer informes, é necessário dar um sentido socialmente positivo em relação ao sexo, capaz de integrar 0 indivíduo na vida social. A informação sexual é útil e necessária, mas por si só não educa. A falta de orientação e informação, aliados aos conhecimentos equivocados e estereotipados, deixam um vasto campo para que as crianças elaborem seus próprios julgamentos e respostas, favorecendo o aliciamento dos agressores (YANO; RIBEIRO, 2011).

Documentos como o Plano de Enfrentamento à Violência Sexual e à Exploração Comercial de Crianças e Adolescentes (Brasil, 2000) traz contribuições relevantes e urgentes ao combate da violência. Contudo, este documento não oferece subsídios para refletir sobre a 
sexualidade como elemento integrante do desenvolvimento infantojuvenil enquanto expressão incorporada no crescimento humano, desde o nascimento do bebê até a fase adulta e além.

Abraçar uma perspectiva mais abrangente sobre a sexualidade de crianças e adolescentes é fundamental, sobretudo quando inseridas em um espaço de cuidado institucional, onde se dará, portanto, boa parte do desenvolvimento de sua personalidade e identidade, inclusive a identidade sexual.

Para as crianças ficarem protegidas das violências sexuais, é preciso conhecer a sexualidade e entendê-la num contexto adequado à idade, de acordo com o desenvolvimento delas. É necessário permitir que a criança tenha um entendimento saudável do mundo e possa participar dele também através de orientações e informações adequadas (YANO; RIBEIRO, 2011).

A legislação brasileira no Código Penal e no Estatuto da Criança e do Adolescente aborda definições sobre as modalidades criminais de violência sexual contra esse público, como abuso sexual, pedofilia, estupro, aliciamento, exploração comercial, etc., imprescindíveis para a responsabilização jurídica de agressores e proteção das vítimas (Código Penal, 1940; ECA, 1990).

Porém, não contempla a questão da defesa da dignidade e liberdade sexual, de modo amplificado, visto que, a partir dos 14 anos é compreendido que o adolescente pode ter ato sexual com adulto, mas não estipula a faixa etária permitida (Código Penal, 1940). Isto é, a partir dos 14 anos de idade, pode-se ter relações sexuais com outrem que tenha 40 anos? $\mathrm{Ou}$ isso configura violência sexual? O contexto internacional compreende que sim, configura, e por isso recomenda, fortemente, o estabelecimento de parâmetros para prever em lei a margem de diferença de idade plausível para a atividade sexual entre adolescentes.

Para exemplificar, na Suíça há o estabelecimento de três anos de diferença etária, portanto alguém com 14 anos pode relacionar-se sexualmente com outrem de até 17 anos de idade para se subentender que houve consentimento mútuo. Os parâmetros legais nos Estados Unidos prescreveram até 5 anos de distinção etária, portanto, um adolescente de 14 anos, pode praticar atos eróticos com outro de até 19 anos. As leis brasileiras, todavia, precisam 
avançar para adotar uma margem etária que proteja nossos jovens (Lei 8.069/90 de 13 de julho de 1990, Confederação Suíça).

O desenvolvimento interno é cabível de ser considerado ao ponderar sobre a maturidade do indivíduo. Deste modo, a maturidade também é gerada pelo diálogo com a criança e adolescente para fornecer informação e assim proporcionar o desenvolvimento intelectual sobre a sexualidade. Contudo, há poucos espaços de fala construídos com a criança e adolescente na rede de garantia de direitos.

A sexualidade deve ser abordada de modo holístico, não apenas de modo negativo, ao ressaltar a questão da violência e do enfrentamento aos crimes sexuais contra tal público. Mas também trazer luz sobre a faceta da sexualidade como expressão da personalidade e individualidade, relação afetiva... Assim como investir no diálogo sobre tal temática é igualmente importante em outras realidades familiares não institucionalizadas (FOUCAULT, 1976).

As crianças e adolescentes quando percebidos na dimensão de sua sexualidade apenas como vítimas, sofrem o apagamento da dimensão de sujeito de direitos sexuais que possuem, cabíveis de proteção inegável, porém também sujeito que precisam ter sua dignidade integral zelada.

As crianças e adolescente possuem direito a participação em espaço nos quais são construídos regulamentações e projetos que lhe dizem respeito. Portanto, pode ser enriquecedor escutar as suas opiniões para coconstruírem um plano de intervenção aplicável aos abrigos. Para isso, seria útil a articulação de rodas de conversa, a fim de oferecer espaço de troca de narrativas e reflexões que superem os não-ditos nos abrigos (MELO, 2010).

A Secretaria de Direitos Humanos da Presidência da República tem trabalhado para regulamentar e nortear como esse tema pode ser cuidado no SAICA, mas, sobretudo, é relevante o engajamento em construir uma margem etária protetiva. Deste modo, é proeminente aprofundar os estudos sobre referências exitosas da comunidade internacional ao criar caminhos de como construir leis acerca dessa problemática, não contemplada pelo ECA ou pelo Estatuto da Juventude. 
As leis que mais aproximam-se desse debate concernem à sexualidade em instituições fechadas ou de regime semiaberto, como a Fundação Casa, quando o adolescente se encontra em regime de internação devido a delitos que incorram na privação de liberdade, na qual a partir dos 12 anos de idade é previsto direito à visita íntima. Deste modo, a Fundação Casa é uma instituição que dispõe de espaços separados para estas modalidades de visita em algumas unidades de internação, sendo que tal direito é garantido para o caso de sujeitos casados ou em união estável (BRASIL, 1990).

Talvez os profissionais de abrigos precisem pensar se acaso seria interessante ter um espaço com semelhante finalidade. Além de fortalecer parcerias com a área saúde para discutir acerca da prevenção de doenças sexualmente transmissíveis e de gestação precoce.

O debate pode ser ampliado à temática sobre a valorização do corpo, dignidade sexual e construção de afeto, promoção do fortalecimento do respeito entre crianças e adolescentes, para compreensão dos limites das relações e prevenção de violência, dialogando também sobre a concepção de consentimentos e as relações entre indivíduos com distância etárias muito discrepantes. Possivelmente o estilo musical do funk carioca poderia servir de recurso para provocar pensares importantes.

O Conselho Nacional de Direitos Humanos das Nações Unidas discute os Direitos Sexuais e Reprodutivos de crianças e adolescentes por meio de marco teórico e referencial de saúde sexual e saúde reprodutiva de adolescentes e jovens (Secretaria Especial dos Direitos Humanos, 2006).

A convenção sobre os direitos da criança e do adolescente refere-se sobretudo ao adolescente em conflito com a lei, o que poderia eventualmente ser juridicamente aplicável àqueles que vivem em abrigos, para repensar ações ligadas ao fortalecimento de laços comunitários afetivos, inclusive de namoro, que pode ser uma maneira de expressão desses laços de afeto. Portanto, discutir essas questões configura desenvolver ações embasadas na proteção da integridade holística da criança e do adolescente (Convenção sobre Direitos da Criança, 1989).

Um fator de interferência que pode ser um obstáculo para as demandas relatadas serem transformadas em projetos inseridos no cotidiano do abrigo consiste no fato de que muitas 
instituições de acolhimento são religiosas. Contudo, diante da laicidade que caracteriza o serviço público estatal, mesmo nos abrigos conveniados, é necessário abrir espaço laico para proporcionar tratar de questões da sexualidade.

\section{MÉTODO}

O presente trabalho recebe fortes inspirações e contribuições teóricas do campo da Etnografia, assim como para análise dos dados observados a partir das lentes da Antropologia com subsídios da etnografia dos Estudos Sociais da Infância, referente às concepções das singularidades dos grupos familiares e de suas culturas (Fonseca, 2005). Sendo que o fazer etnográfico é vinculado à prática e à experiência no campo de pesquisa, por meio da continuada reflexão sobre os conhecimentos de tal ciência em articulação com a observação de grupos sociais urbanos e suas relações com a cidade e suas instituições, seus comportamentos, valores e dinâmicas culturais na contemporaneidade (Magnani, 2008).

A pesquisadora vivenciou a realidade cotidiana de crianças e adolescentes em serviços de acolhimentos durante aproximadamente três anos de imersão durante sua experiência profissional. Época na qual realizou registros importantes sobre o dia a dia das crianças e de suas relações familiares e comunitárias, em relatórios, prontuários, materiais de estudo e discussão de casos entre a equipe institucional, bem como registros semelhantes a diários de acontecimentos importantes, tanto agradáveis quanto árduos da rotina do abrigo. Além da experiência obtida durante as atividades desenvolvidas no decorrer do período de mestrado, especificadas abaixo.

A primeira etapa da pesquisa de campo proporcionou ricas ponderações comparativas entre a realidade brasileira e a de Portugal, mais especificamente, na Cidade do Porto, onde houve imersão da pesquisadora, quando pôde contatar instituições e pesquisadores para dialogar, bem como conhecer serviços de acolhimentos, órgãos e profissionais da proteção da infância, inseridos no citado contexto europeu. Trechos das experiências desta fase da pesquisa foram incluídas no corpo do trabalho, principalmente no capítulo que aborda a importância das nomenclaturas adotadas na elaboração de políticas públicas. 
Os serviços de acolhimento visitados no exterior e a política institucional frente à temática da reinserção familiar foram descritos, em meio as diferentes questões legais referentes ao fenômeno das crianças em situação de rua, apresentando as peculiaridades dos dois cenários pátrios. As reflexões dentro dessa temática foram decorrentes do intercâmbio acadêmico que ocorreu em 2017.

$\mathrm{Na}$ segunda etapa da pesquisa de campo, duas famílias foram entrevistadas com objetivo de acessar narrativas sobre o processo de reinserção e deserção familiar que vivenciaram. Os participantes das entrevistas são sujeitos que possuem histórico de vivência em situação de rua e que também passaram pelo processo de reinserção familiar após habitarem o serviço de acolhimento, situado na região norte da cidade de São Paulo.

Integrantes da equipe institucional que atenderam tais famílias também participaram das entrevistas estruturadas, de modo a comtemplar as questões centrais dos processos de reinserção e de deserção familiar experienciados pelos entrevistados, contribuindo com informações sobre os casos e relatos, também ao compartilhar sobre as práticas utilizadas pautadas no cuidado e apoio às famílias.

No início da pesquisa, o abrigo supracitado foi escolhido para realizar a pesquisa, então foram escolhidas duas famílias do mesmo. Contudo, as crianças de tais famílias passaram por outras instituições de acolhimento durante o decorrer da pesquisa, conforme elucidado no Diário de Campo.

O método da entrevista etnográfica foi adotado para realizar o levantamento de dados contidos nas narrativas das crianças, famílias e profissionais, pois possibilitaram maior flexibilidade para exploração do assunto na interlocução com os entrevistados (Beaud, 2018). Levantamentos a partir de fontes documentais da instituição de acolhimento e diário de campo descritivo também foram recursos utilizados.

Os documentos institucionais como prontuários do serviço de acolhimento foram analisados com a finalidade de observar as medidas tomadas em distintas vertentes, ao visar o processo de reinserção familiar. As famílias foram contatadas para a realização de entrevistas, a fim de investigar como o processo de reinserção familiar sucedeu, como transcorreram possíveis deserções familiares e seus desdobramentos. 
As entrevistas foram realizadas durante visitas domiciliares, entre outros ambientes acordados conforme a preferência apresentada pelas famílias, ao considerar também os diálogos em contextos informais, com anotações realizadas, gravações de áudio e transcrições parciais das entrevistas.

Os encontros aconteceram em visitas aos abrigos, nos quais ora parentes da criança estavam presentes, ora ausentes. A residência de familiares das crianças também foi espaço utilizado para entrevistas, em alguns destes momentos contou-se com a companhia das crianças junto aos seus familiares. Além de instituições da rede de serviços, como a Defensoria Pública, que também foi lugar de encontro com sujeitos de pesquisa. Outras ocasiões que oportunizaram conversar com as famílias se deram em passeios ao shopping e em visitas às instituições como a Defensoria Pública.

A pesquisa descreve assim aspectos da história de vida pessoal das crianças, adolescentes e familiares, o que auxilia na investigação dos fatores atrelados à saída de casa para o circuito das ruas, até chegar à institucionalização, e o percurso quanto à reintegração familiar, dentre rupturas de seus percursos.

Deste modo, a transcrição parcial das entrevistas buscou trazer maior aproximação com a linguagem e costumes dos participantes, sem ater-se à normas gramaticais que poderiam artificializar ou causar distanciamento dos discursos obtidos. Deste modo, para apresentar fidedignidade com as práticas de comunicação dos nativos e da cultura transmitida por meio da fala, gírias e informalidades serão preservadas nas transcrições.

Para não expor os entrevistados, optou-se pelo uso de nomes fictícios na apresentação dos dados da pesquisa. As condutas éticas foram estabelecidas de acordo com as considerações contidas na resolução no 510/16, referente às pesquisas em Ciências Sociais e Humanas. Diante do objetivo de resguardar a identidade e sigilo das pessoas entrevistadas, foram atribuídos nomes fictícios também para os funcionários institucionais e não foi revelado o nome da instituição participante da pesquisa.

A análise de dados obtidos foi feita sob a perspectiva das Ciências Sociais da Infância. Para tanto, procurou-se articular os conteúdos das entrevistas, dos documentos estudados e dos registros do diário de campo com tal vertente teórica. 
Nesta pesquisa, o termo criança ou crianças serão designados para pessoas abaixo dos 18 anos, de forma geral, de acordo com a conceituação adotada na legislação internacional, embora a nacional defina que crianças são aqueles menores de 12 anos, adolescentes os maiores de 12 e abaixo de 18 anos.

A concepção de família adotada ao longo da pesquisa parte do pressuposto teórico de Szymanski (apud SZYMANSKI, 2002:10), que entende a família como "uma associação de pessoas que escolhe conviver por razões afetivas e assume um compromisso de cuidado mútuo e, se houver, com crianças, adolescentes e adultos", isto é, um conceito de laço familiar que não é restrito ao vínculo consanguíneo.

\section{ENTREVISTAS ETNOGRÁFICAS DO DIÁRIO DE CAMPO}

\subsection{Narrativas de crianças, familiares e equipes institucionais}

Atuei profissionalmente em instituições de acolhimento para crianças, bem como em equipamento de acolhimento para grupos familiares e serviço de atendimento para crianças em situação de rua. Três anos nos quais vivenciei profunda imersão nesses ambientes e onde pude observar e analisar hábitos, práticas sociais, discursos que indicam valores, crenças e culturas.

Nessas instituições haviam oportunidades frequentes de observar e participar de encontros entre crianças e suas famílias, recebendo visitas familiares no serviço socioassistencial, ou acompanhando as crianças até a residência de suas famílias, e realizando visitas domiciliares de equipe sem a companhia das crianças. Contingências ricas para visualizar as interações políticas e sociais em sua complexidade de sistemas de significados, este período possibilitou conhecer e acompanhar as histórias de diversos grupos familiares, ainda que parcialmente.

A partir do início do presente estudo, a experiência de imersão profissional já tinha sido finalizada. Fui encontrada pelas crianças de dois grupos familiares distintos que estiveram acolhidas em um mesmo abrigo no qual estive em parte da minha trajetória laboral, serviço distinto do qual se encontravam quando o reencontro sucedeu. $O$ encontro com o primeiro 
grupo ocorreu presencialmente em um transporte público, sem qualquer agendamento prévio, onde a pesquisadora se deparou com quatro irmãos acompanhados de sua avó Hilda.

A posteriori, em contato com o abrigo no qual os conheci, foi possível acessar prontuários contendo endereço e telefone para contato. O telefone estava desatualizado, mas o endereço permanecia o mesmo, portanto uma série de visitas domiciliares foram realizadas para o levantamento de dados e de narrativas de tal família. Inclusive, a realização das entrevistas ocorreu nos passeios pelo bairro da avó Hilda e também no espaço da atual instituição de acolhimento na qual as crianças são atendidas agora também foi lugar visitado na companhia de Hilda, o que possibilitou dialogar com a equipe institucional.

O encontro com o segundo grupo se deu pela atitude de Valentina que encontrou meu contato nas redes sociais e adicionou-me. A garota enviou mensagens compartilhando os acontecimentos de sua atualidade e, ao destacar que sentia saudade, solicitou então que um encontro fosse combinado. Espaços da rede de garantia de direitos da Assistência Social e da Justiça como a Defensoria Pública, a Vara da Infância e Juventude, o abrigo posterior, e o Shopping mais próximo desse abrigo foram lugares para a realização da pesquisa de campo e das entrevistas com esse grupo familiar protagonizado pela Valentina junto de sua mãe e madrinha Celeste.

Os dois grupos familiares supracitados vivenciaram o acolhimento ao longo de anos desde a primeira infância, provaram do processo de reinserção familiar e conheceram a pesquisadora quando atuou profissionalmente numa instituição de acolhimento, situada na zona norte de São Paulo, em 2015, serviço que permitiu a realização da pesquisa e contribuiu com entrevistas. Os dois outros serviços de acolhimento para onde os grupos familiares foram destinados também foram visitados pela pesquisadora, o que possibilitou diálogos com a equipe, porém não houve consentimento para acesso aos documentos institucionais como o outro mencionado.

\subsection{Narrativas de Valentina, Celeste e profissionais}

Valentina tinha 17 anos no nosso reencontro, sua família lhe concedeu ao todo 13 irmãos: 4 maternos e paternos, 6 maternos e 3 paternos. Desses dois faleceram adolescentes, um 
decorrente de homicídio por dívida com tráfico de psicotrópicos e outra por conta da patologia denominada Lúpus. Os quatro irmãos que são paternos e maternos são aqueles com os quais ela possui maior proximidade e afinidade: Vitor (15 anos), Vagner (16 anos), Valentim (18 anos), Vilmar (19 anos).

Segundo relato de Celeste e Valentina, a mãe de Valentina a amamentou até seus 6 meses de vida, quando foi presa por envolvimentos com infrações atreladas a furtos. Com 7 meses Valentina foi acolhida junto com dois irmãos também ainda bebês. Enquanto os demais irmãos estavam acolhidos em outro equipamento de acolhimento.

Celeste era cuidadora na instituição de acolhimento que recebeu Valentina bebê e acompanhou o seu desenvolvimento deste então. Porém, posteriormente Valentina foi acolhida na instituição de acolhimento Aldeia. Mensalmente recebia visita de seu pai idoso que estava adoecido, com câncer, então ele veio a falecer quando Valentina tinha 8 anos de idade. O pai de Valentina em seu leito de morte pediu que para sua filha primogênita Ana que cuidasse dos seus filhos e os levasse para morar consigo.

Nesta ocasião Ana (45 anos) que é irmã paterna mais velha, desacolheu Valentina e cuidou de seus outros irmãos. Todos os irmãos tinham aparência que remetia aos traços paternos, exceto Valentina que se assemelha muito a mãe. Ana tinha desavenças com a mãe de Valentina, pois o pai abandonou sua mãe para ficar com mãe de Valentina. Tal abandono levou Ana e sua mãe a ficarem em situação de rua por determinado período. Por conta de todo este pano de fundo Celeste e Valentina acreditam que Ana inferiorizava Valentina no tratamento concedido, diferente do disponibilizado aos demais irmãos. Interfaces de tal história também foram encontradas nos relatórios institucionais.

Os castigos físicos eram constantes de Ana para com os irmãos que estavam sob seus cuidados. Segundo Valentina, além das violências física sofridas, Ana tratava a Valentina e seus irmãos de forma discriminada da tratativa atribuída aos filhos de Ana, por isso ela trancava geladeira e armários da cozinha, e fazia sopas para alimentar Valentina e seus irmãos, enquanto Ana, seus filhos e marido alimentavam-se com uma refeição muito melhor.

Quando Valentina completou 12 anos de idade, não suportando mais as violências de Ana, a adolescente fugiu de casa e ficou perambulando pelas ruas, até que foi abordada pela 
polícia que a direcionou ao Conselho Tutelar para ser acolhida institucionalmente, de novo. Valentina então morou com a família ao lado de Ana durante 4 anos, até que se deparou com situações de maus tratos.

Celeste informou que sempre que possível, isto é, quando não existia impedimento institucional ou familiar, buscou manter contato com Valentina desde sua infância até o momento presente.

Valentina tinha forte aptidão para despertar seguidores de sua liderança no grupo de atendidos pelo abrigo, inclusive em situações delicadas e de tensões relacionais. Ela tem um comportamento agitado, diálogos um pouco infantilizados, pele negra, com sorriso travesso e frequente.

Ana também passou parte de seus anos de vida em serviços de acolhimento, e quando completou a maioridade conquistou sua autonomia, desacolheu os irmãos do contexto institucional e os trouxe para morar consigo em 2013. Então, ela morava com marido e filhos quando possibilitou a reinserção familiar dos irmãos que passaram a viver juntos. Como Valentina considera as regras de convívio Ana muito rígidas, morar com os irmãos nunca foi uma possibilidade, visto que estão com Ana.

Atualmente, Ana trabalha em um salão de beleza e como técnica de enfermagem, além de ser estudiosa e estar fazendo curso de enfermagem em uma instituição privada com custos populares.

Desde 2015 quando a pesquisadora trabalhava no abrigo de Valentina, a irmã Ana se recusava a receber visitas de Valentina quando ela queria ver os irmãos, mesmo quando as visitas eram acompanhadas por uma educadora da instituição. Segundo Valentina, os desentendimentos com Ana motivaram-na a decidir morar com Celeste em 2015, momento em que já se referia a ela com o termo "mãe".

Ao longo de meses do processo referido, entre visitas e atendimentos pela equipe do abrigo à Celeste que sinalizaram o quanto ela também desejava conviver com a adolescente em sua casa e estava organizando sua vida para recebê-la - até havia mobiliado um quarto para adolescente - e já tinha condição financeira de the oferecer sustento. Celeste sempre 
fazia visitas ao abrigo para estar na companhia de sua filha de coração - assim era o modo como fazia referência à Valentina.

O processo de reinserção familiar era pautado por procedimentos institucionais de articulação de visitas de Celeste para a adolescente no abrigo, além de finais de semana programados para Valentina dormir na casa de Celeste. Inclusive, foram realizadas visitas domiciliares da equipe institucional para conhecer o ambiente de moradia de Celeste, para avaliar o quanto se apresentava de modo saudável para a adolescente ali morar, entre outras práticas de cuidado da psicologia e assistência social promovidas pela equipe.

No mesmo ano de 2015 se deu o contexto no qual Valentina saiu do abrigo para ir à escola e não retornou mais, pois foi morar com Celeste. Então, como parte da equipe do abrigo, realizei novamente visita domiciliar para dialogar com Celeste e Valentina sobre a informal saída do abrigo. Celeste estava feliz com a decisão de Valentina e deste modo decorreu sua reinserção familiar. Até mesmo conseguiu guarda provisória em contato com a VIJ mediante as orientações dadas sobre a necessidade de regularizar juridicamente a tutela de Valentina.

O processo de reinserção familiar já estava em vias de ser finalizado, com as práticas mencionadas acima focadas no fortalecimento de vínculo familiar entre ambas, embora ainda faltasse a articulação com a Vara da Infância para oficializar o laço de adoção. Porém, conforme descrito, Valentina antecedeu a conclusão do processo e, aos 14 anos, partiu e resolveu que não retornaria ao abrigo, inclusive não comunicando os profissionais responsáveis em nenhum momento. Valentina ficou dois anos na casa de Celeste.

Por conta da casa de Celeste ser longe dos seus contatos pessoais, já que Celeste mora fora do município de São Paulo. Por não ter amizades no bairro de Celeste, Valentina mencionou que ficava bastante tempo assistindo seriados da Netflix e passeava quando podia. Afirmou que gostou muito do tempo em que morou com sua mãe Celeste, pois não tinham muitos confrontos, diferente de como costuma ser na relação com sua irmã Ana.

Valentina chama Celeste ora de mãe, ora de madrinha, a depender do estado emocional no qual se percebe. Quando está feliz ou fragilizada a chama de "mãe", quando está brava ou desapontada com Celeste prefere o termo "madrinha". 
A relação com tal figura materna indicava ser tão importante que durante as experiências problemáticas no abrigo, houve momentos nos quais, após a escola, Valentina não retornava para o abrigo, mas sim ia até a casa de Celeste. Ou seja, nas vivências difíceis ela não procurava a família consanguínea, mas não hesitava em buscar a presença da Celeste.

As narrativas de Valentina revelam relações com parentes marcadas por conflitos, sofrimentos e autoritarismo. A irmã primogênita, por exemplo, Ana, enfatiza para Valentina que essa deve distanciar-se de Celeste se quiser ter contato com seus irmãos e familiares consanguíneos. Interdição acompanhada da justificativa de Ana acerca da consideração de que Celeste é permissiva e por isso sua presença não traz boa influência para sua irmã. Fato que angustia Valentina, pois não quer renunciar a nenhum desses laços afetivos que sustenta há longos anos. Valentina tem contato com os irmãos esporadicamente, quando Ana permite, desde 2015 até o tempo presente.

$\mathrm{Na}$ instituição anteriormente mencionada, a pesquisadora conheceu Valentina e sua família, atendendo-a como psicóloga e educadora terapêutica. No transcorrer de situações de grande estresse, como por exemplo quando discussões desembocavam em heteroagressões e/ou autoagressões, ela se desorganizava, ao ponto de não conseguir estar dentro do abrigo de forma minimamente segura. Diante da prática alinhada em equipe,eu a chamava para dar uma volta, dialogando, até que ela encontrava meios de elaborar alguns de seus sentimentos e tranquilizar-se suficientemente, para retornar ao abrigo.

Situação extremamente singular diante do contraste com o protocolo comum em diversos abrigos que lidam com situações acaloradas assim ao lançar mão de recursos como expulsões dos envolvidos, por meio de transferência institucional ou da criminalização de crianças, direcionando aqueles percebidos como algozes do conflito à Fundação Casa, ou mesmo encontrando outras formas de atribuir penalidades, como desprovê-los de passeios ou visita familiar por determinado período. Mais adiante será relatado como algumas dessas práticas revitimizadoras foram adotadas pela instituição na qual Valentina ficou posteriormente, em 2019.

Antes, em agosto de 2018, Valentina entrou em contatou comigo pelas suas redes sociais, enviou mensagem com relato de que estava em um abrigo da zona norte paulistana. $\mathrm{Na}$ 
tentativa de auxiliar na compreensão sobre a razão de ter deixado de morar com a Celeste após mais de dois anos para voltar a viver em um abrigo, Valentina esclareceu:

"Eu estava bem na casa da minha mãe, tia. Mas fiquei sabendo que meu irmão estava muito mal, estava na rua e se envolvendo com roubo, correndo o risco de ir pra Fundação. Aí falei pra ele pedir pra ir pra um abrigo, que assim eu também iria pro mesmo abrigo pra ficar com ele e ajudar ele".

Então, foi quando Valentina deixou de morar com Celeste, embora estivessem tendo uma convivência agradável. Pediu ao Conselho Tutelar para ser abrigada no mesmo serviço de acolhimento no qual o irmão estava. Assim, Valentina retornou ao contexto de viver num abrigo. Contudo, quando chegou na instituição, soube que o irmão acabara de ser internado na Fundação Casa, onde permaneceu por meses. O plano de Valentina foi inexitoso.

Na sequência Valentina solicitou ao abrigo poder voltar a morar com Celeste. Contudo a equipe mencionou que a possibilidade estaria aberta mediante autorização judicial intermediada pela Vara da Infância. No acompanhamento na VIJ, entretanto, o juiz concedia estava alinhado com a equipe do abrigo e concedeu a orientação de que ela melhorasse o comportamento social apresentado no abrigo para demonstrar que estaria preparada para voltar a morar com Celeste.

Deste modo, Valentina circulou por seis abrigos a partir do momento que tentou encontrar o irmão, ficando por quatro meses no primeiro, na zona leste, o segundo, uma casa de passagem, na região central, o terceiro e quarto nas extremidades da zona leste, o quinto na região norte e o sexto era situado em local mais próximo de sua família de origem, em uma instituição em outra área da zona norte.

Quando retomou contato pelas redes sociais, Valentina compartilhou que não estava bem ao ponto de ter tentado se matar. Na sequência, enviou duas fotos, uma na qual estava com o braço engessado, outra mostrando uma grande cicatriz que atravessava o pescoço, horizontal e frontalmente. Pediu ajuda, todavia recebeu a informação da impossibilidade devido a minha ausência em decorrência de viagem. Em uma conversa delongada foi oferecido contato com instituições públicas de referência que poderiam auxiliar, diante do sofrimento que ela estava vivenciando. 
Tentativas de suicídio e atos de automutilação eram acontecimentos recorrentes em seu histórico, desde o início de sua adolescência, sobretudo em situações limites. Os episódios se manifestavam em momentos de crise, de grande impacto emocional e estresse.

Valentina relatou, então, alguns atritos que vivenciou no abrigo e que são considerados pelo juiz da VIJ como indicadores de que ela precisa melhorar sua conduta antes de passar pela reinserção familiar junto à Celeste. O juiz fazia menção ao envolvimento em conflitivas, como relatou Valentina acerca de quando um garoto tentou forçá-la a ver a nudez de outro menino do abrigo que estava usando o banheiro. Para isso, o primeiro puxou o cabelo dela para mover o rosto na direção na qual o segundo estava e, então, ela o agrediu para tentar impedir que ele a conseguisse fazer ver.

De tal situação, muitas agressões foram geradas por e contra Valentina, inclusive gerando a necessidade de engessar o braço dela por cerca de três meses, fraturado e lesionado no confronto, como ilustrou a fotografia. Neste período, o abrigo orientou Valentina a não ir para escola, pois a lesão não a permitia escrever as lições e, ela, então, faltou neste tempo, conforme detalhou Valentina.

A pesquisadora já conhecia muitas das cicatrizes da adolescente, mas havia diversas novas, como a do pescoço e outra que atravessava o pulso. Ela relatou que havia tentado suicidar-se, que estava muito triste com o que estava vivendo no abrigo, mas que começou a fazer acompanhamento psicológico e percebia que estava melhor.

No mesmo período, Celeste, igualmente, entrou em contato comigo, afirmando que a filha por vezes comenta sobre mim, acerca da época que era psicóloga no seu abrigo anterior, destacando que Valentina afirmava que sentia saudade e que gostaria de me rever, pois eu a ajudava muito.

A entrevistadora realizou contato com o abrigo já com a expectativa de realizar uma visita à Valentina. Todavia, ao falar com a assistente social, informando que já havia sido psicóloga de um abrigo no qual a Valentina esteve, e que diante da tentativa em retomar contato, eu gostaria de saber como poderia agendar uma visita, recebi resposta de que seria necessário verificar com a equipe se haveria possibilidade e aguardar retorno. 
A partir desse momento, iniciou a reflexão sobre a possibilidade de ter levantado resistências institucionais, por conta da forma como transcorreu a apresentação entre pesquisadora e equipe institucional, por eu não ser vista apenas como uma amiga da Valentina, mas sim como alguém que tem um olhar técnico conhecedor do que é plausível ou inadmissível dentro de um abrigo. Portanto, possivelmente a recusa quanto a possibilidade de visita poderia estar associada à perspectiva do abrigo em ver a entrevistadora como potencial fiscalizadora institucional, que poderia prejudicar o serviço de acolhimento com denúncias de possíveis irregularidades.

Poucas horas após meu contato, recebi telefonema da assistente social dizendo que dialogou em equipe, e avaliam que neste momento não seria viável minha visita, pois já tiveram problemas com visitas da mesma garota. Também mencionou que Valentina nunca falou sobre mim para os profissionais e, então, entediam que não era um vínculo de seu interesse prioritário. Comuniquei Valentina quando soube da negativa do abrigo quanto à minha visita e das justificativas apresentadas, irritada verbalizou:

"Ela está metendo o loco, eu já falei de você sim, e vou falar de novo, e vão ter que deixar você me visitar aqui, sim. E também posso sair e podemos nos encontrar em outro lugar".

Esse diálogo ocorreu pelas redes sociais. Deste modo, orientei que ela se acalmasse, falasse de mim novamente para equipe, e que também pedisse a Celeste para reforçar o seu pedido, informando que me conhecia. Assim, eu poderia visitá-la no abrigo, e caso não autorizassem, agendaríamos noutro lugar. Diante da nova recusa do abrigo, Valentina e eu nos encontramos em um shopping próximo à instituição num final de semana, onde conversamos e aproveitei para compartilhar sobre a pesquisa e a convidei para participar, apresentando as considerações éticas de sua colaboração.

Anteriormente, a mãe de consideração, Celeste, já havia se disponibilizado para fazer uma visita comigo, porém existia a dificuldade de conciliar agenda com celeridade, devido à especificidade de sua rotina de trabalho de cuidadora em uma Casa Lar (instituição de acolhimento) com poucas folgas, inclusive desalinhadas com o cronograma de visita institucional.

Após cerca de um mês, o abrigo retomou contato comigo para informar que repensaram e estavam receptivos para que eu visitasse Valentina e que gostariam de conversar comigo. 
Agendamos e compareci. Quando cheguei, Valentina estava no portão dizendo que estava me esperando e que já estava ansiosa. Falou que lá há muitos grupos de irmãos e que só ela está lá sem ter alguém, então destacou que era muito bom receber uma visita.

Antes de poder passar mais tempo com Valentina, após esse breve instante quando nos cumprimentamos, uma educadora disse que primeiramente a equipe gostaria de falar comigo. Fui conduzida até a sala da equipe onde dialogamos. Durante a conversa, questionaram qual a natureza da minha relação atual com a adolescente, bem como se tenho interesse em desacolhê-la para trazê-la para morar comigo.

Repeti o que já havia dito sobre ter trabalhado em um abrigo onde ela foi acolhida, e contei que ela havia encontrado-me e entrado em contato. Falei também a respeito da pesquisa de mestrado, a temática e a participação da Valentina como sujeito de pesquisa. Então, a assistente social do abrigo solicitou que eu não compartilhasse com Valentina o fato de que ela participaria da pesquisa. Informei sobre a importância ética de tratar sobre esse assunto com Valentina com absoluta transparência, visto que ela já tinha conhecimento de tal fato e aceitou participar.

$\mathrm{Na}$ conversa junto à equipe do abrigo, além da assistente social, estavam presentes também a diretora da instituição e a psicóloga. Queriam compartilhar que estão preocupadas com o fato de que, em cerca de três meses, ela completará 18 anos e não tem um horizonte de possibilidades muito favorável.

"A Celeste realmente é a única pessoa que busca contato com Valentina com frequência, diferente da irmã que sempre a trata com hostilidade. Celeste demonstra ter afeto por ela, mas o problema é que ela não exerce uma figura de autoridade e de limites para Valentina, ela é muito permissiva. Por isso estamos pensando e conversando com a rede sobre como podemos fazer para de repente a Valentina ir para uma República (SAR) e começar a trabalhar pra ter autonomia quando sair daqui, porque não vamos apoiar que ela fique com Celeste e nem a Vara vai, então é uma saída que a gente está vendo pra ela”.

Descreveram que percebem a reciprocidade de carinho entre as duas, mais do que com qualquer outra pessoa que a Valentina conheça, pois enquanto os familiares consanguíneos não a visitam, sequer telefonam, nem convidam para passar um final de semana em suas casas, Celeste por sua vez, faz tudo isso e com frequência quase sempre semanal. 
Ainda assim, a equipe não percebe elementos suficientes para trabalhar a reinserção familiar entre ambas. As entrelinhas da narrativa das funcionárias do abrigo sinalizam que acreditam que as duas juntas não formariam uma família estruturada o suficiente, então não poderiam conceder suporte a essa alternativa.

Declararam que Celeste precisa de mais do que amor para poder cuidar bem da Valentina. Por isso, na articulação com a rede de serviços, com a VIJ, o abrigo enfatizou que não irá se posicionar a favor de que ambas morem juntas. Então, elucidaram o quanto percebem que os laços consanguíneos são permeados por diversos episódios de conflitos, hostilidade e distanciamento, portanto consideram inviável que ao completar 18 anos Valentina more com familiares, ou seja, com Ana e irmãos.

A equipe se posicionou dizendo que estavam tentando encontrar outras opções de vínculos significativos que possam oferecer suporte para Valentina e, por isso, também tiveram abertura comigo, a fim de assegurar se eu seria uma possibilidade de desacolhimento para Valentina, isto é, se eu gostaria que ela morasse comigo. Mencionaram que estão unindo esforços para estimulá-la a fazer um curso profissionalizante, para começar a trabalhar, a fim de desenvolver sua autonomia e independência, para viabilizar ser encaminhada para o acolhimento institucional para maiores de 18 anos.

Concluíram questionando sobre a natureza da minha relação com Valentina, explicitei em resposta que já fui sua psicóloga e educadora terapêutica, mas no presente tenho sido alguém com quem ela desabafa e pede ajuda, e que tento contribuir como posso, encontrando-a, orientando, contudo, sem pretensão de desacolhê-la.

Coloquei que meu papel também é de pesquisadora, enquanto ela é uma colaboradora de pesquisa. Respondi na sequência que apesar da Celeste realmente não ser uma mulher das mais rigorosas, ela e Valentina poderiam refletir se assim como elas moraram juntas por mais de dois anos, recentemente, e tiveram bom convívio, eventualmente poderia fazer sentido repensar se retomar essa convivência teria potencial para uma experiência positiva.

Após fui conduzida para conversar com a Valentina que estava muito carinhosa, recebeume com abraços e levou-me até a brinquedoteca para conversar com privacidade. Contou que está preocupada com seu aniversário chegando e não sabe o que vai acontecer quando sair do abrigo. 
Comentou que o serviço de acolhimento não quer que ela more com Celeste e que a irmã dela, Ana, somente aceita que ela vá morar com ela, desde que Valentina rompa relações com a Celeste, exigência estabelecida acompanhada da justificativa de que essa condição se deve ao fato de Celeste influenciar Valentina a se distanciar da sua família de sangue.

Afirmou não concordar porque sempre busca estar com os irmãos, mas nem sempre Ana consente que se aproxime. Valentina contou também que o abrigo não quer que ela more com a irmã, pois vê essa relação como muito instável e hostil. Agradeci a ela por dividir comigo o que estava acontecendo e compartilhei que a equipe tratou desse assunto minutos antes, e partilhei um pouco do que dialogamos.

Ressaltei que já tinha entendido sobre como estava configurado o posicionamento do abrigo, mas que gostaria que ela pensasse no que ela deseja. Ela disse que prefere morar com a Celeste, mas que se o abrigo não deixar ela pode tentar morar com a irmã.

Com estranhamento refleti que não parecia que estava diante da mesma Valentina que quando não queria estar no abrigo, da escola deslocava-se para a casa da Celeste sem precisar ter a autorização do abrigo e que inclusive protagonizou o próprio processo de reinserção familiar, sem esperar o tempo institucional de elaborá-lo por completo.

Destaquei que seguir as regras da casa é algo importante, contudo, esclareci que aos 18 anos as escolhas de sua vida seriam pertinentes a ela e não à instituição, já que aos 18 anos ela não está mais sob a tutela do abrigo ou do Estado. Portanto, orientei a pensar com calma e decidir. Independentemente, de sua escolha ser consonante com a do abrigo.

\section{3 À flor da pele}

Valentina relatou que estava chateada com a equipe do abrigo e sentindo que queriam the prejudicar. Comentou sobre a razão de seu braço ainda estar imobilizado com gesso, decorrente de ter sido agredida por um garoto do abrigo. E que ficou indignada porque os profissionais do abrigo não fizeram nada, sequer o repreenderam. Nem a levaram ao médico mesmo com ela dizendo do quanto estava com dor decorrente da fratura óssea. Só foi ao médico uma semana depois do incidente. Esse acontecimento ela já tinha 
compartilhado, contudo não com a riqueza de detalhes que costuma ter quando conta presencialmente suas experiências.

Após esse dia, prosseguimos nos falando ora em encontros presenciais, no abrigo ou no shopping e ora por mensagens enviadas virtualmente, até que ela me contatou com seu celular. Dividiu que estava muito preocupada, pontuando que um garoto a estava provocando, insultando, enquanto ela estava tentando ignorar e manter a calma, até que a chamou de "corta-corta" fazendo menção ao acontecimento recorrente de sua automutilação e das tentativas de suicídio quando suas emoções estão à flor da pele oriundas de situações estressantes. Por fim, quando ele a chamou assim, ela disse:

"Aí eu perdi a cabeça e fui pra cima dele. Dei um soco na cara dele, mas como ele é muito branquinho, não é negro como eu, ficou super roxo. O pessoal do abrigo levou a gente pra delegacia e fez um BO (Boletim de Ocorrência) contra mim, e falaram que vão me levar pra Fundação Casa pra que lá eles decidam o que vai acontecer comigo. Estou com muito medo de ficar presa. Eu falei que aqui eles querem me prejudicar, quando o moleque quebra meu braço, não fazem nada com ele, quando eu tento me defender de quem está me provocando, eles vêm e fazem isso comigo".

Valentina contou que após isso acontecer ela não poderia mais sair do abrigo, pois foi proibida pela equipe até segunda ordem. Só poderia ir para escola, com horário bem controlado para saída e retorno. O confronto ocorreu em uma sexta-feira à noite. No sábado, ela já havia sido transferida para outro abrigo que tem a mesma administração do anterior. Na manhã seguinte, uma segunda-feira, ela foi apresentada pelo abrigo na Fundação Casa.

Durante uma das visitas realizadas ao abrigo, o assunto acerca da transferência foi abordado e obtive a seguinte narrativa de Valentina:

"O menino tem um grupo de irmãos com ele no abrigo, então os irmãos defenderam ele e me culparam. E as tias do abrigo não queriam separar eles porque eles são irmãos, aí me tiraram de lá. Disseram que é provisório, pois vão achar outro abrigo que será meu definitivo, mas que ainda não encontraram vaga". 
Nessa fase, os contatos tornaram-se mais intensificados, ela parecia angustiada e desesperada com o que estava acontecendo. Entrei em contato com meus amigos da área do Direito para que pudessem me orientar sobre como poderia ajudá-la para evitar que ela tivesse sua liberdade restringida.

Estas advogadas ofereceram orientação de ir com ela na Defensoria Pública da Fundação Casa na qual tramitava seu caso, a fim de que ela pudesse conhecer quem faria sua defesa e pudesse compartilhar a sua versão dos fatos e de sua história de vida, dando mais elementos para o advogado público defendê-la com mais propriedade.

Seguindo os direcionamentos, solicitei que Valentina e Celeste fossem comigo na Defensoria. Lá, com todas presentes, fomos atendidas e orientadas sobre as etapas do processo. Primeiro uma oitiva para ouvir a parte acusada, a vítima e as testemunhas, sem a presença de um Defensor Público. Depois, pode haver uma segunda oitiva com a presença do Defensor, ou pode ser agendada a audiência para o julgamento, diretamente. $\mathrm{Na}$ segunda oitiva, o promotor também pode finalizar o processo, ao atribuir uma consequência atenuada através de advertência ou remissão, porém pode dar continuidade no processo, com audiências e com aplicação de medidas socioeducativas.

Valentina, orientada por Celeste, disse a equipe do abrigo que precisava ir à casa de uma amiga da escola para fazer um trabalho em grupo, pois acreditavam que falar a verdade, de que iriam na Defensoria Pública, poderia inviabilizar a autorização da saída da jovem. Na Defensoria Pública, a estagiária e assistente jurídica que nos atenderam, além de informar sobre os dados do processo e do $\mathrm{BO}$, também fizeram apontamento a respeito do trâmite jurídico dos fatos que sucederiam, da forma burocrática detalhada acima.

Ela apresentou a carta que eu a ajudei a escrever que seria um relato breve em sua defesa, pois ela acredita que estaria nervosa demais na audiência para conseguir explicar o que houve. A assistente jurídica viu a carta e mostrou para a Defensora que estava presente no plantão, que por sua vez orientou que a carta não fosse utilizada na primeira oitiva, mas sim na segunda ou na audiência.

Deu instruções de que Valentina apenas falasse que ele estava the provocando e que ela perdeu a calma e lhe bateu, sem conceder mais detalhes sobre os desentendimentos e 
chateações que ela tem com o abrigo, como mencionado em parte do conteúdo da carta, pois isso poderia "pegar mal" (sic) com o promotor.

Não puderam informar o nome do defensor designado para o caso, afirmaram não ter essa informação, apenas um número que indicava que o defensor era da Vara da Infância de Santana. Entregaram os dados do processo e concederam as elucidações abaixo que nos deixaram mais aliviadas.

"De forma geral, nenhum adolescente é preso por dar um soco no outro. A internação com privação de liberdade é para atos mais graves. Portanto, lesão corporal pode incidir nas medidas socioeducativas de liberdade assistida ou de prestação de serviços comunitários, além de possibilidades ainda mais brandas por intermédio de Advertência, Remissão e Prestação de Serviço Comunitário“.

Na Defensoria Pública, afirmaram que o mais adequado seria ser muito objetiva e breve na sua fala, dizendo apenas sobre o seu problema psicológico, e que foi provocada e, como não tomou seu remédio no dia, não conseguiu manter a calma. Depois, na segunda e opcional oitiva, com a presença do defensor público designado para o caso dela, seria mais cabível falar dos detalhes do ocorrido, inclusive sobre ela não ter se sentido protegida pelo abrigo quando foi ofendida, além de poder apresentar a carta com seus motivos para o incidente.

A estagiária da Defensoria Pública que prestou atendimento, comentou que o promotor que estaria na oitiva era um pouco "chatinho" (sic) e que gostava de "pegar no pé" (sic) dos adolescentes, então que se ele falasse algo para "pegar no pé" da adolescente, ela não deveria "dar bola" (sic).

Diante do nervosismo de Valentina que a atrapalhava comunicar judicialmente o ocorrido, uma advogada de meu contato pessoal direcionou-me a dar orientações à Valentina de que mostrasse suas cicatrizes do braço e do pescoço e dissesse que foi humilhada por causa destas marcas corporais, e ao ter sido humilhada contra-atacou para defender-se, enquanto a equipe do abrigo não o fez. A advogada ressaltou que fazer assim ao evidenciar provas visíveis e concretas de que ela está talvez mais ferida do que o outro garoto, visível e invisivelmente, por conta das consequência emocionais. Logo transmiti essas recomendações para Valentina. 
Quando chegou a data da oitiva, segundo o relato da Valentina, a mesma ocorreu sem a presença do defensor, apenas ela, o promotor, a assistente social do abrigo e a diretora do abrigo. A oitiva teve duração de menos de 5 minutos. $\mathrm{O}$ promotor leu o $\mathrm{BO}$ que afirmava que ela havia cometido lesão corporal. Ele perguntou se fora isso mesmo o que aconteceu. Ela relatou que respondeu que o garoto a estava provocando e que ela perdeu a cabeça e Ihe bateu. Segundo Valentina, o promotor afirmou que: "não existe isso de perder a cabeça, mas que se ela gosta de ficar perdendo a cabeça, um bom lugar para isso é a Fundação Casa".

Ainda de acordo com as palavras da adolescente, o promotor perguntou para equipe do abrigo como era o seu comportamento na instituição, então a assistente social do abrigo respondeu "Ah! Ela demanda muito!". O promotor prosseguiu declarando: “Um bom lugar para ficar demandando muito é a Fundação Casa". Valentina acrescentou que na sequência foi agendada a audiência para a próxima quinzena e então encerrou a sessão. Portanto, conforme a descrição de Valentina, na oitiva não havia ninguém para representá-la e defendê-la, enquanto as palavras de acusação e criminalização da assistente social e do juiz Ihe foram proferidas.

Antes da audiência, tentei verificar com a Valentina a possibilidade de irmos descobrir quem seria o seu defensor público, a fim de conversar consigo e instrumentalizá-lo da melhor forma para defendê-la na audiência, mas Valentina não quis. Aguardei alguns dias e insisti, mas ainda assim ela recusou e reduziu as conversas que costumávamos ter. Então, concedi espaço que ela parecia estar buscando.

No dia da audiência perguntei como havia sido. A resposta que obtive foi:

"Normal".

Mesmo tentando entender melhor, ela não quis conversar a respeito. Ao contatar Celeste para ter alguma notícia sobre o que foi definido na audiência, também não obtive informações. Celeste apenas disse:

"Não sei de nada, ainda tenho que ver com o pessoal do abrigo para as técnicas me explicarem. Tentei ligar, mas não consegui falar com elas porque parece que tinham ido pra Vara, alguma coisa assim externa do abrigo". 
Dias depois, Valentina contou que na audiência o juiz não definiu a consequência que seria estabelecida. Perguntei se o defensor tinha apresentado argumentos em seu favor e ela informou que não, que o mesmo ficou em silêncio durante a audiência inteira. Esse silêncio pode sinalizar que ele não verificou o processo, nem a sua carta que foi anexada ao processo contendo justificativas em sua defesa.

$\mathrm{Na}$ segunda oitiva, segundo relato de Valentina, o seu defensor permaneceu silente, sem apresentar qualquer apontamento ou argumentação em seu favor, e o juiz informou ouviu a psicóloga e diretora do abrigo que fizeram apontamentos contra Valentina, segundo descrição que ela me apresentou. Inclusive, complementou que o juiz atestou que o caso prosseguirá adiante, então agendou audiência para o final de setembro.

\subsection{Brincadeira e sexualidade}

Noutro dia, Valentina me contatou referindo estar muito preocupada, queria conversar imediatamente, mas não era viável nos encontramos de forma urgente, por conta disso a entrevista ocorreu por meio do telefone, antes da audiência e presencialmente após tal ocasião. A duração do contato por telefone foi de 40 minutos e pessoalmente 2 horas, na casa de Celeste.

Parte do tempo Celeste estava ausente, por conta da sua agenda de trabalho. O objetivo da entrevista era buscar compreender o que estava angustiando Valentina, assunto que ela não queria compartilhar de modo prévio ao nosso reencontro presencialmente. Adiante segue seu depoimento, aparentemente truncado e constrangido.

"Tia, vão fazer outro BO contra mim. É difícil de explicar... Aconteceu umas coisas lá no SAICA... uma brincadeira, mas aí eu estou levando a culpa, é difícil explicar. Preciso de algum advogado, você pode me ajudar, tia? É que eu estava brincando no quarto do abrigo com as meninas minhas amigas. Tinha mais três meninas comigo. A gente teve uma ideia de a gente fazer marca de chupão no pescoço da gente, pra causar e parecer que a gente está ficando com os moleques. Daí depois os tios do abrigo viram o chupão no pescoço da menina mais nova, ela tem 10 anos, e perguntaram pra ela quem foi e ela falou que foi eu, contou que era brincadeira. Mas os tios fizeram BO contra mim de estupro de criança”. 
Valentina esclareceu que além de Janaína de 10 anos, estavam na brincadeira a Natália de 12 e a Dalila de 15 anos. Mas como ela, Valentina, era a mais velha, a equipe de profissionais inferiu que ela era responsável e que um abuso sexual ocorreu, não uma brincadeira com consentimento mútuo. Além disso, outro evento relatado no BO consistiu no fato relatado a seguir.

"Outra coisa foi que as meninas pediram pra experimentar meu remédio do psiquiatra porque elas tinham curiosidade de ver se dava alguma brisa legal, e eu deixei, cada uma pegou um e tomou. Os tios ficaram sabendo. Ai tia, me ajuda por favor! Eu nem sei quem contou tudo pra eles, mas eles colocaram no BO que eu queria deixar uma criança drogada e estupra (sic) uma criança também. Não foi nada disso, e agora eu posso ir ficar atrás das grades por causa de uma brincadeira de amigas. E minha mãe nem vai poder me visitar porque nem é da família".

Desse modo, Valentina fez menção aos limites da informalidade de sua relação com Celeste. Na comunicação com Celeste, ouvi o desabafo de como estava imensamente aflita com a gravidade do que estava no $\mathrm{BO}$, inclusive informou que a equipe do abrigo encaminhou a questão para o DEIJ (da Fundação Casa situado no Brás) julgar e a audiência seria realizada na segunda semana de agosto de 2019.

Ambas compartilharam que a audiência contou com a presença do promotor de justiça, psicóloga do abrigo, Celeste e Valentina. Declararam que Valentina foi absolvida e que o promotor decidiu encerrar o caso, ao invés de levá-lo a frente, pois interpretou que não havia ocorrido ilegalidade. Tanto Valentina quanto sua mãe destacaram como se sentiam aliviadas em saber que a adolescente sofrerá a restrição de sua liberdade. Celeste acrescentou outro tema abordado na ocasião, conforme especificado abaixo.

"Você acredita que a psicóloga do abrigo me disse que eles queriam que a Valentina fosse encaminhada pra um abrigo porta de entrada ${ }^{9}$ até conseguirem uma vaga numa República para ela! Mesmo comigo e com ela falando pra eles que queremos ficar juntas, que quero que ela more comigo. Falei disso com o promotor também e daí a assistente social aceitou que a Valentina pode vir morar comigo, mas acho que só aceitou porque o promotor falou".

\footnotetext{
${ }^{9}$ Instituição de Acolhimento vaga emergencial e provisória, possui alta rotatividade pois seu objetivo e receber e encaminhar atendidos para outros serviços com vaga fixa (Resolução CNAS/CONANDA, 2009).
} 
Apesar dos esforços institucionais contrários, com a maioridade Valentina optou por voltar a morar com Celeste, com quem tem vivido agora. Celeste rapidamente providenciou transferência da matrícula escolar de sua filha para perto de sua casa, onde elas estão morando. Agora Celeste está providenciando atendimentos de saúde para a adolescente permanecer em acompanhamento pelo SUS de sua região. Geralmente, essa articulação de rede é protagonizada pela equipe profissional do serviço de acolhimento, porém neste caso sucedeu de maneira diferente.

O aniversário de Valentina ocorreu no final de agosto quando completou 18 anos, portanto em setembro ela já teria maioridade penal e seu processo de agressão ao garoto do abrigo, que tramitou no DEIJ, não poderia mais conduzi-la à Fundação Casa, então precisaria ser encerrado. Assim aconteceu o desfecho de tal narrativa.

\subsection{Caminhos para contatar Hilda e seus netos}

No decorrer do ano de 2015, a pesquisadora atuou profissionalmente no abrigo onde as crianças a seguir também estavam acolhidas. A configuração do grupo familiar é a seguinte: Sandra (37 anos) é mãe de Marcos (14 anos), Luan (12 anos), Vinicius (8 anos) e Daniela (7 anos). Hilda (45 anos) é mãe de Sandra, logo, avó das crianças. Fernando (29 anos) é filho de Hilda, assim como Larissa e Sandra, tios das crianças. Fernando é o único filho de Hilda que mora com a mãe. Larissa tem uma bebê chamada Laura.

Em julho de 2017, enquanto visitei um contato pessoal, num bairro periférico da Zona Norte, vi no banco de trás do transporte público as quatro crianças acompanhadas pela avó. Cumprimentei-as e elas foram muito afetivas e tagarelas. Contaram que estavam morando com a avó e que a mãe estava internada em um serviço de saúde para tratamento de uso abusivo de drogas. Contaram que era muito bom morar com a avó e que frequentemente visitavam a mãe. As crianças estavam sorridentes e animadas, porém a avó parecia muito cansada, pelos traços de seu semblante.

Esse fato ocorreu antes do início da pesquisa de campo. Durante a etapa de análise e validação do projeto de pesquisa, ao compartilhar esse fato a banca sugeriu, oportunamente, contatar a esta família para o levantamento de entrevistas.

Em contato com o abrigo, solicitei observar documentos da mesma família de crianças, como prontuários e dados dos atendimentos recebidos. Assim, foi possível acessar mais 
informações sobre a história das crianças, inclusive dados sobre endereço e telefone da avó. Embora o número telefônico não estivesse mais atualizado, o endereço residencial mantinha-se inalterado.

Fui então até a casa, mas não havia ninguém presente. Alguns adolescentes da vizinhança observaram-me batendo palmas no portão. Então, perguntei-Ihes se conheciam Hilda, ou a seus netos, e se sabiam que horas costumavam estar em casa, para eu retornar e encontrá-los. Em resposta afirmaram que as crianças não estavam mais morando ali, pois estavam no abrigo havia certo tempo e que a avó Hilda deveria chegar à noite do trabalho.

Retornei no final de semana à tarde, Fernando apareceu pela janela e desceu as escadas para atender-me. Informou que Hilda não estava em casa, porque estava na sua igreja evangélica e demoraria para voltar. Então, solicitei o telefone para contata-la e compartilhei sobre eu já ter trabalhado com seus sobrinhos no abrigo e estar interessada em conversar com ela e com eles. Ele passou-me o contato e confirmou que as crianças estavam morando em um abrigo. Também entreguei meu contato e pedi para encaminhá-lo a ela.

\subsection{Narrativas da avó Hilda}

Por telefone, agendei com Hilda algumas visitas e todas as vezes que nos encontramos ela foi muito acolhedora. O objetivo das entrevistas consistia em realizar observação participante do estilo de vida de Hilda e de sua família, bem como dialogar sobre a relação estabelecida entre ela e seus familiares, para ouvir sobre as perspectivas de desacolhimento de seus netos para promoção da reinserção familiar, entre percalços e deserções vividas.

Ocorreram cerca de 10 entrevistas, com duração de 3 horas cada, realizadas em sua casa. Ambiente que denota a simplicidade de seu modo de vida e dificuldades econômicas da família, pois têm pontos de umidade nas paredes com tijolos espaçados que permitem entrada da água da chuva no interior da residência, entre outros reparos necessários que Hilda explicou:

"Está vazando a laje, mas só vou conseguir arrumar as coisas da casa mais pra frente". 
Foram realizadas por volta de 10 visitas da pesquisadora na casa da avó Hilda ao longo do primeiro semestre de 2019. Deste modo, proporcionou-se uma diversidade de diálogos com avó e com as suas crianças sobre a trajetória que percorreram. As narrativas eram intercaladas por atividades da rotina familiar na casa da avó, principalmente, no final de semana. Outro espaço utilizado foi ao passear pelo bairro com as crianças, que mostraram a quadra onde jogam futebol e brincam no parque situado em uma pré-escola pública.

Hilda compartilhou os acontecimentos desde anteriores ao momento em que nos vimos no transporte público até a atualidade. Contou que as crianças voltaram a viver no abrigo, e lá estavam institucionalizadas no presente porque ela tinha de trabalhar, resolver coisas fora de casa e não conseguia dar conta de tudo e ainda cuidar de suas necessidades.

Explicou que tentou muitas alternativas antes de considerar o acolhimento. Tentou levá-los para o trabalho, onde atuava com diarista na limpeza de casas. Considera que a sua patroa era compreensiva e por isso a autorizou, porém, como eles ficavam brigando entre si, mexendo nas coisas, tornou-se inviável continuar levando-os consigo ao trabalho. Ainda sobre tal assunto, Hilda esperava poder contar com a ajuda de Fernando para os cuidados com as crianças, até considerando a alternativa de trazê-las para morar consigo, consoante ao que descreveu adiante.

No fórum (VIJ) já me perguntaram, "Você vai cuidar das criança?" (sic). Eu falei que é complicado porque o Fernando viaja muito. Responderam que um dia o Fernando vai casar, vai sair de casa e a responsabilidade vai ficar comigo. Minha renda não chega a mil reais por mês. Sou artesã e diarista. Tenho que mexer com reforma na minha casa, mas mexer com reforma gasta mais que construir.

Comentou sobre alguns dias que tentou deixar as crianças sob os cuidados de seu filho Fernando, mas ele estava indisponível para isso, por conta de compromissos pessoais. Esclareceu que quando deixava as crianças em casa, os conflitos entre eles eram tão críticos que os vizinhos vinham procurá-la, preocupados para contar o que havia acontecido na sua ausência. Um tentou se jogar pela janela com cerca de dois metros de altura, mas os vizinhos interviram. Outro começou a sair de casa para andar com pessoas que aliciavam garotos para o tráfico. Enquanto outro usou uma faca de casa para causar agressões em um conflito que tiveram, dentre outros motivos relatados pela avó. 
"Os meninos estavam dando perdido em mim entrando dez, onze horas da noite. Aí você sabe como que é. Minha rua é fluxo de droga. E tem criança de 12, 13 anos que eles botam para trabalhar no tráfico. Aí eu fui no conselho tutelar e no dia eles arrumaram lá em Itaquera. Lá é um abrigo muito bom, eles estavam até fazendo treinamento num lugar de futebol, porém lá era longe para nós. A gente levava até 3 horas para chegar lá, tinha que pegar três condução (sic). Daí eles transferiram eles para cá."

"Os moleques sempre falam pro Fernando: 'Você fica esperto com a sua rua que ali tem um monte de menor que fica roubando e o tribunal do crime tá de olho'. Os caras do tribunal são do PCC, do tráfico, daí os moleques, eles acham que eles têm sete vidas... Às vezes da janela eu só ouço as meninas gritando: "Socorro, socorro!". Daí você vai olhar, e num instante já não tem mais ninguém na rua".

"Os usuários de drogas já roubou (sic) essa casa aqui do lado. Não dá pra confiar, deixar eles sozinho em casa. Além disso, Marcos não se dá bem com Vinicius, e Dani fica perturbando o Luan. Então, pra mim fazer (sic) as coisa, já num (sic) dava. A minha vida era toda assim, bagunçada e não dava pra colocar em ordem. Vamos ver o que Deus vai fazer. Aqui na frente tem menino e até menina que só entra depois das sete horas da manhã, a minha rua é fluxo de droga. Aqui embaixo do escadão, tem o tribunal do crime, quantos jovens já foram pra lá? Quantos foram e não voltaram?”

Diante deste cenário que suscitou preocupações sobre os riscos da permanência das crianças em casa, Hilda explanou que contatou o Conselho Tutelar (CT) para que eles fossem acolhidos. Primeiramente, o CT providenciou vaga temporária na região da Zona Leste, enquanto uma definitiva seria aguardada mais próxima de Hilda. Ela desabafa que não iria conseguir parar a sua vida como diarista e 'sacoleira' (confecção e venda de produtos diversificados com rendas artesanais e costura) para poder cuidar deles com a atenção que precisavam neste momento.

"Agora fica menos de 30 minutos para a gente chegar lá no abrigo deles. Isso já tem o quê? Já tem uns três meses que eles estão nesse abrigo aqui perto. Fora que não tem horário para ROCAM (Ronda Ostensiva com Apoio de Motocicletas) entrar aqui com tudo. Tem polícia que eles entram e bate (sic), pega (sic) menor... E só não entram dando tiro porque a população já está avisada. Prefiro levar eles pro abrigo do que esperar pra ver onde isso vai dar. Fora que no abrigo eles tem café da manhã, almoço, lanchinho da tarde, janta, outro lanchinho da noite... E aqui não é assim, não tem esse luxo todo. A gente come todo dia, eu 
me esforço pra trabalhar e ter sempre o pão, mas aqui nós não come igual eles estão acostumados no abrigo. Marcos está uma tora! Eles comem bem".

Enquanto as narrativas eram levantadas, as crianças optavam por jogar videogame, assistir filmes, ouvir músicas ou ir brincar na rua. Os diálogos transcorreram enquanto a avó organizava, limpava a casa e cozinhava, lavava roupas, quase que ininterruptamente.

"Hoje vou até cuidar das roupa (sic) da Sandra. Quando ela precisa, ela vem direto aqui e traz um saco de roupa pra eu lavar. A Sandra não tem emprego e na ocupação só entra pra dormir, então ela fica embaixo do viaduto. O que estraga a Sandra é as droga (sic). E ainda têm quatro filhos, de quatro pais drogados."

As relações de suporte se estendem também quando Hilda oferece apoio no cuidado da neta bebê de sua filha Larissa que mora em outro município paulistano. Então, viaja com frequência para visitar e ajudar a cuidar da bebê. Inclusive, lava malas de roupa para a filha que depois vem buscar. Enfim, parece buscar diferentes meios para contribuir com as suas redes de afeto e parentesco, de maneira contínua.

Durante esse intervalo, as crianças pareciam não conversar ou interagir muito entre si, ao menos não nos períodos observados dentro de casa, onde ficavam mais focados nos recursos eletrônicos citados. Apesar de que socializam bastante entre si quando saiam para passear e brincar pelo bairro, aproveitando as atividades de fim de semana na avó Hilda, enquanto os dias úteis eram vivenciados na instituição de acolhimento.

A realidade vivenciada por Hilda passava por dar suporte nos cuidados para filhos e netos, desdobrando seu tempo para cuidar da casa, trabalhar, ajudar em diversas tarefas que os filhos demandavam. Hilda oferece cuidados às roupas de Sandra, lavando-as, porque ela está em situação de rua. Segundo Hilda, Sandra mora ora embaixo do viaduto, ora nos edifícios de ocupações.

"Você sabe que a ocupação é uma fachada de droga para lavar dinheiro? É tudo mentira para mim... A maioria das ocupações não são para ajudar quem não tem uma casa na luta por moradia, não. É tudo fachada de droga". 
"A mãe das crianças também apresenta problemas acarretados pelo uso radical de psicotrópicos. Inclusive, Hilda acredita que os prédios de ocupação consistem em fachadas para disfarçar a ação de venda de drogas no interior desses edifícios. E muitas das vezes Sandra pegava os meninos, e colocava pra ir no farol pedir esmola, pra ela usar droga".

Indaguei sobre como as crianças saíram do abrigo onde os conheci, atuando profissionalmente. Hilda relatou que após a equipe a qual eu pertencia ter sido alterada devido ao CREAS ter selecionado novos profissionais para conveniamento, houve um dia de visita familiar em que a mãe das crianças, Sandra, foi autorizada a passear com os filhos na praça próxima ao abrigo, desde que retornasse até o horário combinado. Destacou que passeios assim aconteciam, eventualmente. Contudo, o retorno não adveio.

Hilda discorreu sobre a percepção que tinha do abrigo, depois da alteração institucional, e que pensa que Sandra estava incomodada com a mudança, que não confiava na equipe da época.

“Lá estava uma bagunça, tanto que o Ministério Público mandou fechar de tanta criança que fugia e de coisa errada que acontecia lá. ${ }^{10}$ Tanto que quando a Sandra levou as crianças, o pessoal nem me avisou. Foi quando eu fui visitar que fiquei sabendo do que aconteceu. $E$ depois disso, eles fizeram um Boletim de Ocorrência de desaparecimento dizendo que fazia três dias, mas não duvido que pode ter sido muito mais tempo. Essa equipe parecia que, pra turma que eles pegaram, eles estavam muito despreparados. Parece que estavam investigando, parecia que eles estavam desfocando dinheiro, verba, não sei. Eu não botei firmeza neles".

Depois de muito tempo, mais de um ano, Hilda soube que Sandra levou seus filhos para um prédio de ocupação do centro de São Paulo e ali passaram a viver, entre dias morando nas ruas e outros em prédios ocupados quando possível. Neste episódio, a caçula tinha 3 anos de idade. Passaram um período de mais de um ano morando juntos nesta condição. Até que o pai da Daniela, homem que também estava em situação de rua, teve um conflito com Sandra e a espancou de forma gravíssima. As lesões da violência causaram hemorragia e fraturas ósseas, inclusive fraturas faciais e cranianas.

\footnotetext{
${ }^{10}$ Nos anexos é possível verificar modelo do edital de processo seletivo de organizações para instalação de Serviço de Acolhimento Institucional para Crianças e Adolescentes (SAICA) onde constam os critérios de autorização para funcionamento de abrigo que são alvo de fiscalização externa do CREAS ou no caso mencionado, do Ministério Público.
} 
Fico preocupada com a Sandra. Você espera tudo de alguém que está nas drogas, ela já escapou da morte tinha platina no rosto, vários ossos dela quebraram quando o pai da Dani arrebentou ela (sic).

Conforme a avó relatou, as pessoas chamaram resgate que a buscou de helicóptero, devido à urgência em prestar socorro. O fato foi registrado e disseminado inclusive por jornais. As crianças foram levadas consigo. Sandra precisou ficar longos dias na Unidade de Terapia Intensiva (UTI). Na ocasião de sua internação hospitalar, a equipe de saúde contatou o CT que encaminhou os irmãos para um serviço de acolhimento transitório, conhecido como Casa de Passagem, que, por sua vez, transferiu as crianças, quando encontradas vagas em um abrigo para permanência de longo prazo, no qual estão atualmente, próximo da região de sua família e comunidade.

"Meu sonho é a Sandra ser liberta desse vício pra ela ser mãe. Às vezes, assim, ela pede dinheiro pra cigarro, mas eu não dou dinheiro pra ela. O Fernando não quer ela aqui. Ele já bateu nela, porque ela já veio aqui e ficou levantando a blusa, fazendo escândalo, e o Fernando não gosta dessas coisas. Às vezes ela vem aqui, eu faço as coisas pra ela, procuro ajudar, mas toda casa tem regra, casa que não tem regra é bagunçado. Ela queria dormir aqui, mas ela queria entra (sic) 5 horas da manhã".

Perguntei sobre como Sandra estava e declarou que, frequentemente, ora quinzenal, ora mensalmente, ela a visitava. Sempre pedia dinheiro e alimento. Hilda observa que a conduta da filha oscila de acordo com seu estado de sobriedade.

"Quando ela não está usando drogas ela é boazinha e a gente não tem o que falar dela, ela respeita todo mundo. Mas só que, você tá (sic) entendendo? Ela tem que parar de mexer com droga. E ela tem outro vício muito feio: arrumar homem e esquecer dos filhos. $E$ homem que não presta, homem que vai bater nela. Todos os pai (sic) das criança era (sic) violento com ela. Ela tem quatro filho, um de cada pai, é uma mulher drogada... Então assim o que ela tem de perspectiva para dar pros filho dela? Eu sempre falo assim":

"Sandra, pranta bença (sic) para você colher bença (sic), minha filha. Pranta (sic) o bem para os seus filhos que amanhã na velhice eles que vão cuidar de você". É só ver na rua, hoje os velhinhos que estão na rua é porque antes deixaram seus filho (sic) tudo jogado. 
Enquanto eu, toda vida trabalhei para cuidar dos meus cinco filho (sic), que já são crescidos e nem moram mais comigo. Só o Fernando mora comigo".

"Se eu tenho uma laje é porque o meu filho que pôs pra mim, porque a vida inteira eu trabalhei pra fazer as coisas pra eles. Então meus netos eles respeitam minha casa e perguntam: Vó, posso fazer isso? Posso fazer aquilo? Mas o conflito deles é entre irmãos. $E$ a Sandra, quando está aqui, atrapalha os meninos. Então, a gente quer ajudar, mas eu não posso parar a minha vida. E os meninos, eles entendem. Quando ela morava no lugar onde fazia tratamento pras drogas, fugiu e não continuou no tratamento. É complicado!"

"Aí nesse intervalo, depois do hospital, a Sandra já foi presa por causa de droga e já tá (sic) embaixo do viaduto de novo. Eu só entrego na mão de Deus. Têm famílias que são unidas, mas tem família que ao invés de ajudar, fica tumultuando. Eu não levo meu problema pra igreja, nem pra minha família. Não vou ficar falando mal da Sandra pros outros, se não fica com raízes de negatividade, melancólica e rancorosa".

\subsection{Narrativas das crianças de Hilda}

Os netos de Hilda também compartilharam suas perspectivas sobre as vivências que tiveram desde a despedida no abrigo. O objetivo das entrevistas com as crianças era colher narrativas relacionadas a suas trajetórias familiares, institucionais e sobre a possibilidade de reinserção familiar.

Enquanto apresentaram-me lugares que gostavam de frequentar e brincar no bairro, compartilharam sobre a rotina no abrigo e sobre os feriados e finais de semana com a avó. Alguns encontros ocorreram em visita institucional ao abrigo atual onde se encontram, local visitado enquanto Hilda me acompanhou. Algumas falas da avó Hilda a seguir estão mais focadas nas experiências das crianças, como a colocação abaixo.

"O Luan tá (sic) desde quinta-feira aqui, né? Os outros chegam sábado. Ele está desde quinta porque tem um casal de usuário de drogas que são pais de uma menina lá do abrigo, que disse que o Luan mexeu na parte intima dela, e ela contou pra mãe. A mãe ouviu e disse que já voltava. Quando voltou trouxe um monte de moleque pra bater no Luan. Luan disse que não fez nada. Daí a diretora do abrigo não acredita que tenha acontecido isso, mas como estão querendo fazer mal pra ele, mandaram ele pra cá pra casa pra esperar baixar a poeira lá”. 
"Mas eu não quero envolver família nem nada, porque se eu falar isso pro Fernando pode ser pior. Ainda mais com ele envolvido com esse pessoal de torcida organizada, que já fico com o coração na mão de preocupação com as briga (sic). Mas quem falou do Luan vai ter que provar, se não vai ficar ruim. Lá nem homens dá (sic) banho nas meninas. Por isso o Luan está em casa esses dias. O cara é traficante, mas não consegue cuidar da filha, coloca em abrigo pra inventar mentira e ficar tumultuando".

"Daqui a pouco as aulas começa (sic), ele vai ter que ir embora pro abrigo. Eles vêm aqui às vezes, pega a lotação, ficam duas horas visitando, aí vão embora. Direto falam pros tios do abrigo que eles tão (sic) na rua empinado quadrado, aí pega carona e vem aqui, até sem avisar o pessoal do abrigo. Mas quando é assim o Fernando é bem rígido com eles e faz eles voltarem para o abrigo".

Luan mencionou que estava preocupado com essa situação, mas que a equipe do abrigo confia nele e sabe que ele não faria isso. De fato, relembrando a trajetória de Luan no abrigo no qual o atendi, onde em situações excepcionais cheguei a ficar 24 horas trabalhando, participando e observando a rotina e as relações, e realmente Luan não costumava estar envolvido em situações com sérios problemas. Por fim, segundo Luan, o pai que o acusou estava presente noutro dia de visita familiar no abrigo, posteriormente ao acontecido, e lhe disse:

"Fica suave aí moleque, ninguém vai te atormentar, não, pode ir lá participar da sua visita. Mas eu fiquei de olho bem aberto, porque eu não confio muito nessa família não, pelo jeito que a mãe dela me olha. As meninas adolescentes foi (sic) falar com ela essa fita: 'Se você ficar falando isso do Luan, você vai ver... Ce é loka (sic), o Luan não quer saber de criança, não. Ele é de boa, ele pede beijo pra gente que é adolescente, não pra criança' ".

$\mathrm{Na}$ visita ao abrigo atual, Hilda inclusive questionou o que a equipe tem a dizer sobre o corrido, a diretora da instituição reforçou a percepção referida, ao afirmar que Luan sempre apresenta bons comportamentos, está muito estudioso, por vezes faz travessuras, mas nada de magnitude que suscite preocupação. Então, a diretora continuou a nos dizer que não acreditava que a acusação correspondesse aos fatos.

A equipe do abrigo determinou que ele apenas sairia do abrigo acompanhado de um educador, para resguardá-lo. Então, para ir ou voltar da escola, dentre outras saídas, ele 
contava com a presença do educador do abrigo, de acordo com Hilda, que também acrescentou o apontamento seguinte:

"Esses meninos não têm juízo. Eu sei que o Luan não fez isso que tão (sic) falando, mas eu sei que às vezes eles ficam com umas brincadeira (sic) besta. Marcos até já passou a mão na bunda da filha de um matador daqui. O cara veio conversar comigo pra tirar satisfação e só não fez nada não porque me conhece já há vinte e sete anos que moro aqui. Mas eu falo direto pra ele: "Marcos, respeita que pra morar aqui tem que respeitar".

"Eles não são de fazer coisa errada, mas Marcos tem a boca muito suja, gosta de ficar xingando, aí eu fico preocupada, porque tem gente que leva tiro aqui por causa de xingo. Parece que não tem lei aqui, mas tem, sim. Um dia desses um moleque estava xingando sei lá quem, e os vizinhos reclamaram do barulho que ele estava fazendo e falaram pro PCC. Veio um cara armado do PCC e ameaçou ele, que é bom ele não tumultuar se não vai sobrar pra ele, aí ele já ficou pianinho (sic)".

"Morar aqui é complicado. Um dia a ROCAM estava entrando e veio me perguntar se eu conhecia fulano e ciclano. Já fui logo dizendo que sou nova aqui e que não conheço ninguém. Morar aqui é ser mudo, surdo e cego".

A avó Hilda mora neste local da periferia da região norte paulistana há décadas e já tem consciência de como e quando falar ou calar. Ressaltou que uma das inquietações sobre o período em que os netos moraram consigo, era de que tivessem alguma atitude descuidada, por vezes até por conta de brincadeiras comuns da fase de vida a qual pertencem que poderiam induzir os meninos a colocarem-se em situações arriscadas como as que demonstrou. Detalhou que Marcos é o mais impulsivo, por isso tem mais dificuldade de ser paciente e respeitoso, como declarou abaixo:

"Ele até já chamou a tia do abrigo de vagabunda. Ele não aprendeu a respeitar".

Hilda noticiou que gostaria que seu filho estivesse por perto, pois na ausência de Fernando, por conta das viagens com a torcida de futebol, ela sente que fica sem suporte para lidar com as dificuldades delicadas como a que Luan tem passado. 
"O Fernando é o meu mais velho. Mora comigo, me ajuda. E eu tô (sic) sempre trabalhando para dar de comer. E para comer bem, para tá (sic) todo dia de barriga cheia, tem que trabalhar para ter sempre o dinheiro do pão. Para você ver, os meus netos, eles respeitam a minha casa, eles falam: "Vó posso fazer isso? Vó posso fazer aquilo? Mas a briga, o conflito é entre irmãos. Parece que é por eles ter pais diferentes que eles não se entende (sic)".

Indaguei como eles estavam no abrigo e como esses comportamentos apareciam no relato da equipe institucional. Hilda partilhou como tem percebido a relação entre eles e o abrigo. Comunicou que no começo não foi fácil, mas que eles entendem que era necessário. Agora já estão mais ambientados e comentam acerca das brincadeiras e tempos de lazer que possuem lá. Segundo Hilda:

"Os meninos, lá no abrigo eles estão bem, tem piscina lá, é muito gostoso, eles sempre posta (sic) foto. Lá é perto da delegacia e têm delegados e policiais que apadrinham as crianças e ajudam dando dinheiro e comprando o que elas precisam. Eles direto dão alguma assistência, então também para os meninos não aprontar (sic), né? Porque lidar com adolescente é difícil, né?"

"Vinicius e Marcos batem de frente. Marcos que está com catorze, é o que dá mais trabalho, fala palavrão com os tios. Teve um dia no abrigo que eu cheguei para visitar, aí as tias me falaram: pensa bem, hein? Se quer mesmo desabrigar eles, ficar com eles na sua casa porque eles vão acabar com seus dias de vida!". Mas Marcos também foi quem estava segurando a cabeça da mãe no colo quando ela foi espancada e dizendo pra ela, chorando: "Não dorme, não, mamãe! Não morre, por favor!". Os outros também viram tudo, mas ele foi o que ficou mais perto, tentando cuidar dela, enquanto ela estava toda ensanguentada".

Hilda voltou a destacar sobre os desentendimentos entre irmãos. Por vezes, para evitar embates nos dias em que visitam a sua casa, ela precisou deixar cada um isolado do outro, e entretidos com eletrônicos diferentes para ficarem sem confrontos.

Eles passaram o Natal e o Ano Novo comigo, mas eu deixei eles no videogame, no tabrete (sic), outro no computador, e outro na TV, porque se fica tudo junto é briga na certa. E na rua não dá para ficar muito tempo lá na frente. Até dá para empinar quadrado, mas não dá pra fazer muita coisa. Os meninos, a gente só pode pegar pra morar com a gente quando eles estiverem numa idade que não dê tanto trabalho. 
Ao buscar ter noção de que idade seria essa na expectativa de Hilda, ela mencionou que acredita que pode ser quando eles estiverem mais perto dos 17 ou 18 anos, com trabalho, e mais juízo para não se colocarem em situações de risco, como as declaradas anteriormente.

Hilda reclamou do calor que estava sentindo e pediu para Luan comprar sorvete, perguntando qual sabor era da minha preferência. Mesmo comigo expressando que não precisava se incomodar, insistiu e Luan trouxe sorvete. Noutro dia da pesquisa de campo, vi o local próximo onde Luan tinha providenciado o sorvete e levei comigo para nossa tarde de diálogos.

Enquanto as narrativas eram suscitadas, de pano de fundo havia o som da televisão que começou a transmitir imagens sobre a tragédia em Brumadinho, em Minas Gerais. Logo Hilda mudou o assunto e disse:

"Tive um trabalho lá. Esses dias, fiquei muito depressiva, muito triste com esse negócio de Minas. Eu tenho muitas amigas em Minas, às vezes eu vou para lá pregar, eu sou pastora na minha igreja, sabe?"

Hilda demonstra que é bastante religiosa, ativa em uma série de eventos da igreja, na qual tem um papel empoderado e protagonista em sua comunidade, por ser vista com prestígio por ensinar sobre Deus.

Luan redireciona o assunto e questiona:

Vó você vai levar pro bazar da igreja aquele tênis de cano alto? Ou eu posso pegar ele?

Hilda responde que o tênis pertence a sua mãe, Sandra, que trouxe no final de semana anterior para ela lavar.

Luan conta que está gostando do abrigo, mas gostava mais do outro, que chamou de "nosso", fazendo menção aquele cujo fiz parte da equipe profissional. Afirmou que sente saudade das pessoas, do passeio na cachoeira. Disse que ficou chateado quando trocaram a equipe, em 2016. A fala a respeito dos passeios fez-me recordar das fotos que tenho 
deles em passeios e noutro dia levei para lhes mostrar. Os pequenos e Hilda ficaram contentes em ver as fotografias dos momentos de lazer de 4 anos atrás, inclusive com as fotos na cachoeira recordada por Luan.

Observamos semelhantemente as fotografias de passeios ao Parque Villa Lobos no qual todos andaram de bicicleta. As crianças viam as fotos e faziam comentários positivos, de como se divertiram, do que teve de engraçado na ocasião do retrato. Contudo, Marcos fazia alguns comentários mais negativos. Repetiu por vezes, referindo-se a sua irmã: "Nossa, como a Dani era feia, era horrível!”. E dava risadas.

Ao retomar o relato sobre o abrigo, Luan relatou que todos têm comportamentos intempestivos, por vezes. "No abrigo só quem é santo são os bebês, mas até eles às vezes até pulam do berço“.

Luan mencionou que também passeiam no abrigo atual, mas não com tanta frequência. Ressaltou que o mais positivo é poder estar perto da família, a qual visita sempre que possível. Também compartilhou sobre os namoros, agora que está no princípio da adolescência, e acerca da realidade na escola.

"Eu beijei uma menina e depois de uns dias a gente trocou de namorada, eu fiquei com a namorada do Marcos e ele com a minha. Também estou gostando da minha escola, é legal lá, tenho um melhor amigo de lá e os professores todos gostam de mim, até a coordenadora. A professora é maior legal, você conversa alguma coisa com ela e ela ajuda muito".

Mencionou sobre como foram as vivências no período morando com os irmãos e a sua mãe.

"O tempo que a gente morou com a nossa mãe foi legal! A gente morou no centro, na rua e nos prédios também de invasão. Na rua era legal que a gente brincava bastante, mas era chato que tinha que enfrentar os cara (sic) que mexiam com nossos irmãos na rua. Uma vez, um cara da muleta que fingia que era especial só pra pedir dinheiro, queria me dar uma muletada (sic), daí com minha mãe e meus irmãos, tentamos imobilizar ele. Eu fiquei com um pouco de medo e comecei a correr e escapei. Outro dia o pai da Dani quis bater na minha mãe..." 
Narrou brevemente sobre a ocasião compartilhada por Hilda, da violência sofrida por Sandra. Em seguida, começou a recordar do abrigo anterior.

"Lembra da Manuela, do Pedro? Lembra do Diego? Ele era folgado! Lembro que ele sempre me provocava, e ele me bateu na frente de todo mundo e eu deixei. Só fiquei com o olho vermelho de raiva. Mas teve um dia que eu não aguentei, foi antes de dormir e ele veio mexer com o Vinicius, meu irmão, aí eu fui pra cima dele, nem bati e ele já saiu correndo... Lembra quando o Paulo ficava falando besteira pras crianças, os adolescentes bateram nele, e deram um empurros nele".

As ditas besteiras eram conteúdos sexualizados declarados por um adolescente de 16 anos para crianças a partir de 6 anos.

Hilda havia ido para a lavanderia há cerca de uma hora e neste momento retornou, dizendo:

"Menina, parece que eu não acabava mais de estender roupa da minha neta bebê. Minha filha tinha ficado sem água e trouxe pra eu lavar".

Parou para conversar ao telefone sobre uma encomenda de bolo que ia fazer para vender à amiga, ao indicar buscar diferentes formas de gerar fontes de renda para a economia familiar.

Hilda repreendeu verbal e severamente Luan quando afirmou que ele pegou o leite em pó da neta Laura, que ficaria sob os seus cuidados na próxima quarta-feira. Mostrou a foto da neta de quem falava afetuosamente.

Luan negou ter consumido o leite, em nenhum momento admitiu, mas Hilda afirmou que entendeu porque acabou o açúcar, mencionou que foi porque Luan estava comendo o leite em pó com açúcar. Complementou a argumentação ao rememorar que Marcos foi dormir duas da madrugada e acordou tarde, assim como Vinicius. Somente Luan dormiu cedo e acordou antes de todos, em momento possível de fazer algo escondido da avó.

Salientou que sabia que enquanto estavam dormindo ele estava comendo o que não tinha a sua autorização para fazê-lo. Encerrou o assunto o colocando de castigo, restringindo que 
ele saísse para brincar na rua pelo restante do dia, sendo que era início de tarde. Hilda permaneceu com protestos: "De manhã eles já pegaram uma bolacha sem pedir, sem dividir, daí vem agora de novo pegando leite da minha netinha!". Na sequência, havia um pequeno pedaço de bolo, ela disse que era para fazer milagre e dividir em três partes, para ter um pedacinho pra cada garoto.

Após isto perguntei para Luan como foi o tempo de morar com a mãe, ele respondeu que teve partes legais e partes chatas. Quando reproduzi a mesma pergunta a Marcos, ele contou que era muito chato o tempo que moraram com a mãe na rua. Que ela dava uns sumiços e dizia para ele que era pra cuidar bem dos irmãos por ser o primogênito, enquanto ela demorava muito pra voltar e nem falava onde tinha ido.

Ao longo da interação com os irmãos, Marcos utilizava brincadeiras mais agressivas ou hostis, com insultos sequenciados pelas suas risadas. Pronunciava: "Que idiota! Que imbecil!" e dava risadas. Hilda parece ter hipotéticas sobre as razões para Marcos apresentar este temperamento, até mesmo verbalizou sobre o que a psicóloga do abrigo informou que conversou com ele a respeito do dia traumatizante no qual a mãe estava fatalmente ferida.

"Eles ajudavam psicolicamente (sic), um dia a psicóloga perguntou pro Marcos: "Do que você tem medo?”. Ele respondeu: "Da minha mãe morrer". Naquele dia ela (Sandra) me ligou drogada, e pediu pra eu orar por ela no telefone, eu orei no telefone, já com o coração apertado. Era (sic) 6 da manhã, ela me disse que ia se mudar da ocupação. No mesmo dia de manhã eu vi a TV, e passou um helicóptero sobrevoando e repórter falou: O que é aquilo ali? Foca ali. É uma mulher ensanguentada. E tem uma garrafa de água, estão lavando sangue dela. Aí ele chamou O Águia (helicóptero) pra ir socorrer ela e levar pro hospital. $A$ garrafa de água era do Marcos que tava (sic) segurando a cabeça dela no colo dele e lavando o sangue dela, enquanto as outras três criança estavam ao lado, tudo sentada (sic) na calçada, vendo tudo também. Então esse medo que ele tem, quase aconteceu. Ela levou uma martelada na cabeça, além dos outros machucados. Acho que ela ia mudar de ocupação porque já tava (sic) tendo problema com ele e recebendo ameaça”.

"O vô do Lucas, Beto, viu na TV e foi buscar eles (sic). Tinha uma repórter com eles na delegacia, divulgando que se não aparecesse alguém de sua família eles precisariam ser encaminhados pra um abrigo. Beto buscou eles (sic) e levou pra minha casa. Eu fui pega numa situação! As pessoas que viram como ela tava (sic), falavam que ela já devia estar 
morta. Mas ela tem um anjo que é tão bom que no terceiro dia na UTI ela já estava consciente. Ela tava (sic) cheia de pino e platina. Os dois estavam drogados e ela começou a bater nele, e ele revidou, mas pra matar. Foi isso que ela me contou".

Daniela estava na casa de Hilda, assim como os irmãos, porém Sandra disse que ia na vizinha com a Dani e não voltou mais. Levou a caçula para morar consigo entre as ruas e prédios de ocupações do centro de São Paulo. Hilda e os netos expressaram como ficaram assustados e preocupados. A seguir constam respectivamente as colocações de Luan e Hilda:

"A gente nem sabia que minha mãe ia levar a Dani, eu acho que ela foi pra casa do meu vô, mas a gente não sabe. Eu fico preocupado. Talvez minha mãe esteja cuidando bem dela, mas com certeza não está cuidando melhor que a gente".

"Não dá pra eu ficar com eles, pra você ver, com eles só me visitando a Sandra já aprontou uma dessas, imagina se eles estivessem morando aqui, não dá, não!"

\subsection{Narrativas na instituição de acolhimento das crianças}

No decorrer das visitas institucionais, com duração de aproximadamente 2 horas cada, ocorridas por cinco vezes, o objetivo era fazer observação participante para conhecer um pouco do espaço institucional, descrever sobre o ambiente relacional vivenciado pelas crianças, identificar intervenções voltadas para trabalhar as relações familiares e comunitárias das crianças focadas no processo de reinserção familiar, através da ótica das crianças, da avó Hilda e da equipe do abrigo, sem desconsiderar deserções de suas trajetórias.

No discurso obtido durante a visita domiciliar, perguntei a Luan o que ele achava de eu ir visitá-lo e a seus irmãos no abrigo, ele disse que iria gostar. No próximo dia de visita, acompanhei Hilda e os visitei. O grupo de irmãos mostrou interesse em conversar e foram afetivos comigo. Esclareço que perguntei apenas para Luan, pois o reencontro com as demais crianças ainda não havia acontecido, visto que diante da situação delicada de Luan, encaminharam-no para casa de Hilda antes do final de semana chegar para que todos os irmãos estivem unidos na casa da avó. 
No abrigo, o neto Vinicius mostrou seus desenhos, contou que está gostando da escola, porém estava mais calado que os irmãos. Assim como no contexto de visita domiciliar, ele preferia ficar no quarto fechado, jogando vídeo game, enquanto os demais jogavam na sala, onde a família estava reunida. Isso quando os demais não optaram por sair para brincar na rua.

Dani brincou comigo, abraçou, estava sorridente e se mostrou prestativa, por ajudar a levar doações que chegaram para a instituição, voluntariamente, mesmo sendo pequena e precisando ir e voltar inúmeras vezes para carregar os objetos mais leves. Infelizmente, não tivemos muitas oportunidades de interagir a posteriori, por conta de Sandra ter levado consigo sua filha, poucos dias após, enquanto o grupo de irmãos visitava Hilda, conforme já explicitado.

A diretora do abrigo convidou a avó e a mim para almoçarmos no abrigo com as crianças. Argumentou para a avó que eles ficariam felizes com sua companhia. Vinícius mostrou desenhos do caderno de artes da escola ao longo do almoço e falou das inspirações nos desenhos animados que assiste. Hilda elogiou os desenhos e deu atenção aos netos.

Um dos principais intuitos das entrevistas no abrigo era ouvir mais as crianças, todavia elas compartilharam mais durante as entrevistas de visita domiciliar, apesar disso, no abrigo pude acompanhar diálogos da avó Hilda com a equipe de profissionais e com a diretora do serviço de acolhimento, onde emergiram elementos importantes da história de vida das crianças que complementam os discursos apresentados e abordam também parte dos processos institucionais vivenciados pelas crianças.

As narrativas apresentadas por Hilda à diretora do abrigo serão expostas a abaixo, quando a pesquisadora estava presente, após devida apresentação e consentimento à participação.

A diretora da instituição informou que ainda não estava muito apropriada sobre a trajetória de vida das crianças e gostaria que Hilda compartilhasse em minúcias, inclusive sobre a razão de eles não estarem mais morando consigo. Hilda explicou que os traficantes recrutam meninos da idade deles, detalhou que eles estavam sempre juntos com os meninos do bairro que eram aviãozinho (sic) bem no lugar de venda de psicotrópicos. $\mathrm{E}$ chegou um momento no qual considerou que precisava resolver isso, refletiu, e concluiu que não iria bater ou brigar com eles, pois já havia abordado o assunto e considerava que 
falar ou castigar não surtiria efeito. Então, comentou acerca do conteúdo de seu pensamentos:

"Amanhã, eu vou tomar uma decisão... Aí levei eles no Conselho Tutelar e me falaram que era minha culpa. Eu uma mulher solteira que criou os filhos sozinha, dentro da favela, tenho que ouvir isso?! Depois fui no Fórum (VIJ) e me levaram pra outra conselheira que foi compreensiva. Ela até me disse: "Se trouxerem de novo os meninos pra você cuidar, você não aceita".

Pronunciou a história sobre a agressão quase letal sofrida por Sandra, circunstância na qual levaram as crianças para ir morar consigo, enquanto a mãe recebia cuidados de saúde na UTI, quando o avô de Luan viu na televisão e reconheceu as crianças, buscou-as e entregou na casa de Hilda.

"Eles vieram na minha casa num grau de agressividade, que meus vizinhos viram eles brigando e a Dani até indo pegar uma faca. Onde já se viu uma menina com idade dela fazer uma coisa dessas?! Na mesma semana o Luan estava tentando se jogar pela janela, em tempo de uma desgraça acontecer".

Parte do que Hilda considerava uma desgraça potencial era de as crianças serem vítimas de violências externas aos conflitos que travavam, inclusive de cunho sexual. Além da possibilidade de cometerem infrações perante a lei.

"Na minha rua circula de tudo, tem pedófolo (sic), tem bandido, tem tudo que é tipo de gente atrás de droga. Não dá pra deixar eles sozinho (sic). Antes da Record vir na minha casa que nem (sic) urubu em cima da carniça, porque aconteceu alguma tragédia, eu vou fazer alguma coisa. Tem dia que as moto (sic) da ROCAM entra aqui pra matar. Aqui é um labirinto, você sabe quem está aqui, mas não sabe quem está vindo lá do fundo".

Realmente, a rua de Hilda é situada no início de um labirinto semelhante a estrutura de arquitetura vistas nos morros do Rio de Janeiro, onde há diversas casas simples, acessadas por becos e vielas estreitas que perfazem um grande labirinto distanciado das ruas comuns, alargadas.

"Eu moro lá faz 27 anos, é quase minha vida inteira. E o homem do mercado veio me falar que eles estavam roubando comida no mercado, pra eu tomar mais cuidado deles. Isso ele 
falou porque ele tem consideração comigo, porque eu que evangelizei ele. Se não fosse por consideração, ele já tinha chamado a polícia pra eles".

Enquanto a diretora buscou compreender mais sobre a história do relacionamento de Sandra com suas crianças, Hilda explanou sobre o período de quase um ano no qual Sandra ficou com os filhos entre trânsito pelas ruas, até quase falecer.

Hilda dividiu que a partir daquele momento as crianças foram morar com ela e que após recuperar a saúde, Sandra voltou para o circuito das ruas, até que ficou presa por uns três meses no início de 2019, e contou que a designaram para cumprir 2 anos e 6 meses de trabalho comunitário. Mas, quando ela saiu, disse que ia morar na Baixada Santista, conforme relatou Hilda a seguir.

"Falei que ela tinha que pagar os serviços comunitários, mas ela nem pagou e nem viajou. Um conhecido meu me falou que viu ela no Centro, no viaduto, suja e irreconhecível. Recebi telefonema da assistente social da prisão feminina, aproximadamente, em junto de 2018. Pedi para que não falassem isso pras (sic) criança, porque elas nunca passaram por uma coisa dessas".

Quando Sandra saiu da penitenciária feminina, passou a ficar nas ruas próximas à casa de Hilda, que não permitiu que Sandra residisse consigo por conta de seus comportamentos que afetavam as suas crianças.

"Aí Sandra começou a usar droga aqui na rua, se envolver com os menor (sic) do tráfico e do roubo. Mas ela não morava comigo, mas começou a usar droga aqui na minha rua. Aí os meninos começaram a ver. Até aí eles estavam bem, matriculei eles na escola eles estavam bem. Mas quando ela começou a vir usar droga aqui na minha rua, eles começaram a ver o comportamento da mãe e pioraram, começaram a me dar perdido... Aí eu levei eles pro conselheiro. A moça do conselho me falou que eu sou avó, não sou mãe, não sou obrigada. Ela viu como eu estava, estava quase entrando em colapso".

"Se eu não tivesse o Fernando, era capaz dela até dar na minha cara. O Fernando é calmo, mas não gosta de palavrão. Mas Sandra chegava já xingando... Meus amigos até me falavam: "Não adianta você fazer pelos meninos enquanto a Sandra está estragando". Sabe aquela pessoa que fica agressiva pedindo dinheiro pra droga? Às vezes ela chegava em 
casa tão transtornada que chegava a espumar a boca. E as criança (sic) vendo aquilo. Aí eu estava chegando da escola com o Marcos e ela estava com um menino da idade dele usando droga na rua, aí ele via e falava pra ela, dá licença que a sua turma é aquela lá, apontava pra galera usando droga".

"Agora quando eles me visitaram da última vez, eles ficaram nos jogos do Fernando, no Xbox, no presteicho (sic) e foi um sossego! Eles não queriam saber de rua e não estavam brigando entre eles. Pensei, olha que diferença! Eles fica (sic) melhor quando a Sandra está longe. É triste isso. Ela é viciada, mas tem época que ela fica meses e meses sem usar, mas ela não pode encontrar uns velhos amigos que volta tudo de novo. Esses dias ela me contou: 'Mãe, encontrei o Daniel e ele me pediu perdão'. Uma pessoa que tentou matar, levou ela pra UTI... Mas na hora da repartição das drogas ele pede perdão e ela dá perdão".

Após ouvir a descrição supracitada, a proposta da diretora do serviço de acolhimento no qual as crianças estão atualmente, consistiu em oferecer alternativas para que as crianças pudessem voltar a morar com a avó, sem interferir nos compromissos de trabalho. Por exemplo, uma das alternativas apontada seria de deixar as crianças em um Centro de Criança e Adolescente (CCA), durante o contra turno escolar. Assim as crianças estudariam em período integral, e o abrigo seria responsável por providenciar vaga nesse serviço educacional e recreativo.

A diretora também mencionou sobre possibilidades de auxílio financeiro assistenciais que poderiam ser articulados junto a CREAS - Centro de Referência da Assistência Social. Hilda, contudo, fora contundente em expressar que não seria viável, pois Sandra poderia intervir nesses projetos, além de ressaltar as preocupações com o aliciamento para o tráfico que é tão comum perto de sua residência.

Então, a diretora indagou se seria interessante que a caçula, Dani, fosse disponibilizada para adoção, já que apenas ela tem perfil etário que pais adotivos buscam. Então, prontamente a avó mencionou que não tem interesse em adoção, pois eles são irmãos e devem ficar juntos, salientando que a Dani tem família. Destacou que planeja e deseja trazê-los para morar consigo, mas acredita que precisa que eles estejam mais crescidos, responsáveis, para que a reintegração familiar seja bem-sucedida. Por fim, expressou que trazer a Dani para morar consigo poderia ser uma alternativa na qual ela poderia refletir. 
Diante do expressado, a diretora sugeriu que a partir daquele momento, quinzenalmente, as crianças fossem buscadas para passar os finais de semana na casa da avó. Hilda consentiu e estabeleceu o combinado. No final de semana seguinte, a avó levou os netos para a sua casa. Contudo, Sandra visitou as crianças, disse que iria com Dani até a vizinha e a levou para morar consigo pelas ruas.

Três meses decorreram desde tal fato, enquanto Sandra entrava em contato com a Hilda para informar que Dani estava bem, enviava fotos e garantiu que a matriculou na escola frequentada pelas crianças de seu prédio de ocupação, situado na região central. Fernando e Hilda tiveram a ideia de solicitar que a equipe do abrigo ajudasse a encontrar Dani através de seu nome na base de dados da educação, a fim de descobrir em qual escola estava estudando.

A polícia em articulação com a área da educação desvendou o paradeiro escolar de Dani e encaminhou o caso ao CT que buscou Dani na escola, e a conduziu de volta ao abrigo, junto de seus irmãos. Fernando discorreu sobre o retorno marcante de Dani.

"A Dani chorou muito quando ela voltou porque ela queria continuar com a mãe dela. Até que ela estava bem cuidada, mas a gente não sabe o que de ruim pode acontecer com ela no meio de um monte de gente que a gente não confia, né? Quando ela chegou no abrigo, as tias contaram que o Marcos e o Luan choraram muito, emocionados por ela tá (sic) de volta. O Marcos acho que foi o que mais sentiu a falta dela, porque ele é o mais velho, ele sabe que ele que tem que cuidar dos irmãos menores, e ele é muito apegado a ela".

Durante a visita domiciliar à Hilda, Fernando compartilhou tal perspectiva. Nesta visita Dani estava presente, ao lado dos irmãos. Então, questionei Dani sobre como foi estar com a mãe e ir para outra escola. Dani informou que a escola era legal. Mas sobre residir com a mãe, expressou o seguinte:

"A gente morava numa casinha com um portão bem grande e verde. Era legal morar com a minha mãe, mas o namorado ela era mal. Eu via que ele batia nela e ele também batia em mim".

Hilda, complementou sua perspectiva: 
“Graças a Deus que ela voltou, já está de novo na escola que ela estava antes, também colocaram ela no CCA pra ficar mais difícil da Sandra pegar ela de novo. Deus sabe o que faz, podiam abusar da Dani, podia acontecer muita coisa ruim, mas graças a Deus ela está com a gente".

Neste dia as crianças estavam mais caseiras, apesar do tempo ensolarado, ficaram entretidas com os jogos eletrônicos enquanto dialogaram com a família e comigo. Vinicius ficava provocando a Dani com brincadeiras com cutucões que dizia que não era ele que estava dando. Mas com respostas na ponta da língua a pequena respondia:

"Não tô (sic) bêbada, não tô (sic) cega. Tenho olho pra ver, seu bobão. Pára!"

Interessante perceber a narrativa de enfrentamento e autodefesa de Dani, mesmo com apenas 7 anos de idade.

No decorrer da conversa com Luan ele declarou que está namorando e gosta de trocar de namoradas, não ficar fixo com uma só. Compartilhou que Marcos namorou uma garota mais velha, e que aprenderam no abrigo atual uma regra de que só podem namorar pessoas com até 3 anos a mais que eles ou 3 anos a menos, porque se não pode dar problema. Interessante o debate sobre idade de consentimento nas relações que envolvem sexualidade ser um assunto que começou a ser debatido no contexto da instituição de acolhimento. Possivelmente, por conta da conflitiva que envolveu o Luan.

Quando aproximou-se das 18 horas Fernando e Hilda se organizaram para dar banho nas crianças, pois precisavam retornar para o serviço de acolhimento. Antes as crianças faziam o trajeto de ida e volta sozinhas, mas após o acontecido com Dani, a avô Hilda ficou responsável de acompanhar sempre que Dani for fazer tais deslocamentos. Então, fiz companhia para a família utilizando o transporte público e entregando as crianças no abrigo.

Despediram-se com beijos e abraços, assim que Dani entrou pelo portão gritou: "Tchau vovó, te amo!" 


\section{ANÁLISE DE DADOS}

As relações cultivadas pelas famílias entrevistadas e as narrativas que expuseram estão em consonância com o conceito de família descrito por Duarte (1994) acerca da importância das práticas de apoio mútuo, pautada em tarefas domiciliares do cotidiano, conforme demonstram os trechos retirados e retomados da entrevista etnográfica subcitados contendo as narrativas dos participantes da pesquisa.

Estas características são apresentadas nos enlaces das famílias estudadas no campo, conforme os desdobramentos de reflexões a seguir que analisarão a constituição dos processos de encontros e desencontros na trajetória de crianças que fizeram das ruas sua morada, bem como as narrativas e de suas referências parentais e de profissionais de serviços de acolhimento por onde passaram.

As características dos processos de estreitamento e sustentação das relações familiares, entre pontos de conexão e de encontro que frequentemente apontam ser vivenciados pelas famílias e suas crianças como experiência de reinserção familiar. Enquanto o distanciamento delongado, as rupturas relacionais e o sofrimento psicológico associado a tais vivências de exclusão do convívio na rede familiar, carrega em si a conotação de deserção familiar aos mesmos sujeitos.

\subsection{Valentina entre reinserções e deserções}

A história de Valentina é marcada por inúmeros movimentos de deserções, pelas rupturas entre abrigos e relações familiares. Apenas nos últimos dois anos, já circulou por seis instituições de acolhimento, dentre o total de oito que já foram sua casa. Inclusive habitou as ruas por períodos curtos em torno de um mês a cada uma das vezes que fugia da instituição de acolhimento na qual estava. Não demorasse muito para ser encontrada por agentes da assistência social ou da segurança pública que a direcionavam para o Conselho Tutelar, que por sua vez realizava encaminhamento para 0 abrigo que tivesse vaga disponível.

Explicou que, continuamente, andava em grupo com crianças e adolescentes quando estava em situação de rua. Ressaltou que os meninos do grupo quando abordados por policiais, não tinham a mesma tratativa de serem direcionados para o Conselho Tutelar, mas sim para a Fundação Casa, conforme afirmou ter presenciado algumas situações deste perfil. 
Valentina discorreu que em suas vivências nas ruas havia aventura e liberdade de sentir que poderia fazer tudo o que quisesse, sem precisar ficar seguindo inúmeras regras comuns ao ambiente institucional. No entanto, também sentia que era difícil lidar com perigos, temores de violências, além da questão da fome. Apesar disso, mencionou que nunca aconteceu algo grave consigo quando estava nas ruas, pois estar em grupo e ficar em lugares mais movimentados eram algumas de suas estratégias de proteção.

A organização grupal que se articula para proteção, sobrevivência e resistência, remete a ideia desenvolvida acerca do quilombo contemporâneo, no qual a rua é encontrada como alternativa de refúgio distante das violências recorrentes em relacionamentos familiares abusivos. Este refúgio também é caracterizado por estar à parte do contato com instituições que reproduzem ou maximizam as violências já experienciadas pelas crianças.

Por vezes, o movimento de ida às ruas remetem a concepção da rua como quilombo, pois tal habitat parece ser encarado como uma forma de estabelecer um processo de inserção familiar singularizado, onde o grupo de relações estabelecidas quando se está em situação de rua pode encontrar recursos para sustentar vínculos afetivos, mesmo que temporários, e desenvolver interações mais saudáveis e fortalecidas do que nos núcleos familiares consanguíneos, ou mesmo do que instituições opressoras.

\footnotetext{
Valentina foi abandonada pela sua família e inserida em uma Aldeia (modalidade de acolhimento institucional) desde bebê, com 7 meses de vida. Celeste trabalhava como cuidadora na Aldeia, quando acompanhou o desenvolvimento de Valentina e vinculou-se a ela. Até que com 8 anos de idade Valentina passou a receber visitas mensais de seu pai biológico, já muito idoso e adoecido com câncer. Seu pai tinha outros filhos, inclusive Ana que recebeu um importante pedido no leito de morte paterno. A solicitação consistia em que Ana trouxesse Valentina para morar consigo e cuidasse também de seus irmãos quando o pai perdesse a vida.
}

Após tal pedido, houve o seu falecimento e Ana passou a visitar Valentina ao longo do período de um ano, tempo de realização do processo institucional de reinserção familiar estabelecido pela Aldeia. Terminando este período Valentina passou a morar com Ana, que recebeu sua guarda, e contou com aportes financeiros concedidos pela instituição de acolhimento pelo próximo semestre. Todos os irmãos tinham aspectos físicos semelhantes ao pai, exceto Valentina dotada dos traços e cor de pele de sua negra mãe. 
Anteriormente, quando o pai de ambas iniciou relacionamento conjugal com a mãe de Valentina, ele abandonou a mãe de Ana e seus filhos que passaram por dificuldades socioeconômicas após tal acontecimento, ao ponto de Ana precisar viver em situação de rua ao lado de sua mãe por certo espaço de tempo. Por esta razão Ana sempre destratou Valentina, utilizava castigos físicos que conduziram Valentina a fugir de sua casa. Ocasião na qual tinha 12 anos de idade quando ficou perambulando pelas ruas, até ser destinada por policiais ao Conselho Tutelar que providenciou seu segundo equipamento de acolhimento.

A primeira experiência de reinserção familiar de Valentina, portanto, foi apresentada em sua narrativa e na de Celeste como provida de agressões e vulnerabilidades. Até mesmo Celeste compartilhou e Valentina validou a informação de que Ana já tinha outros filhos e marido quando ficou com a guarda de Valentina e de seus irmãos. Explicitou que em diversas refeições enquanto ela, marido e filhos comiam uma alimentação diferenciada, Ana servia Valentina e seus irmãos com uma sopa simplória. Ainda trancava os armários da cozinha e a geladeira para garantir que as melhores comidas não fossem consumidas por Valentina e seus irmãos.

No início de sua adolescência, de volta ao circuito da rede de acolhimento, Valentina sempre manteve contato afetivo com Celeste, inclusive antes disto, mediante a autorização de Ana. Valentina estreitou sua relação com Celeste, e a equipe do SAICA possibilitou que ela visitasse a adolescente frequentemente, assim como os profissionais realizaram visitas domiciliares e possibilitaram a Valentina passar alguns finais de semana e férias escolares na casa de Celeste. Estas práticas configuravam elementos do processo de reinserção familiar que concluiu-se aos 15 anos de idade de Valentina.

A relação com tal figura materna indicava ser tão importante que durante as experiências problemáticas no abrigo, houve momentos nos quais, após a escola, Valentina não retornava para o abrigo, mas sim ia até a casa de Celeste. Ou seja, nas vivências difíceis ela não procurava a família consanguínea, mas não hesitava em buscar a presença da Celeste.

Dois anos depois Valentina permaneceu com bom relacionamento com Celeste, apesar disso solicitou acolhimento ao Conselho Tutelar para ficar na mesma instituição que seu irmão, a quem tinha intenção de ajudar. Contudo, o encontro com irmão não sucedeu, visto 
que ele foi direcionado à Fundação Casa. Mas a equipe do serviço de acolhimento não autorizou o retorno de Valentina ao convívio com Celeste.

Dentre os obstáculos que mantiveram a adolescente neste último serviço de acolhimento está a concepção de família adotada pela equipe profissional que carece ser despida do julgamento mistificado pautado num modelo idealizado de família. Fonseca (2005) define família como sendo o conjunto de relações entre pessoas com vínculos afetivos que extrapolam os laços de sangue e da unidade doméstica. Portanto, a instituição de acolhimento é caracterizada enquanto obstáculo neste contexto.

Deste modo, oferece perspectiva que busca descolonizar o poder empregado na prática da equipe técnica que intervém sobre as famílias, para que seja situado o fortalecimento dos principais vínculos de cuidado formado pelas interações das crianças assistidas pela rede de proteção da infância e juventude (Quijano, 1992). E para que o projeto de vida da criança seja ouvido e considerado parte da construção do trabalho desenvolvido pela instituição.

O interesse de Valentina em residir com Celeste mostrou-se desconsiderado pelo corpo técnico do abrigo, pois não foi oportunizado espaço de protagonismo e escuta para Valentina opinar sobre seu futuro, nem sequer para dialogar sobre as intervenções institucionais impactantes a sua vida. Essas barreiras de comunicação reforçam uma atuação colonizadora, que despotencializa o papel da criança no planejamento de sua própria história de vida, consequência da fragilidade do diálogo entre os agentes da intervenção e a população-alvo desta intervenção.

Analisar a multifacetada expressão de modos de vida permite reconhecer a diversidade das formas de ser no mundo e nas relações familiares, conforme a autora destaca referente à necessidade de um olhar dialógico para promover a escuta da criança e de sua família em quaisquer etapas de intervenção institucional (FONSECA, 2005).

Até mesmo nas situações onde ocorria diálogo da equipe técnica com Valentina, ainda não havia escuta que demonstrava validar e legitimar a intencionalidade de suas escolhas e interesses, como sinalizado no trecho a seguir, no qual consta a colocação da psicóloga do abrigo. 
A Celeste realmente é a única pessoa que busca contato com Valentina com frequência, diferente da irmã (Ana) que sempre a trata com hostilidade, a Celeste demonstra ter afeto por ela, mas o problema é que ela não exerce uma figura de autoridade e de limites para Valentina, ela é muito permissiva. Por isso estamos pensando e conversando com a rede sobre como podemos fazer para de repente a Valentina ir para uma República e começar a trabalhar pra ter autonomia quando sair daqui, porque não vamos apoiar que ela fique com Celeste e nem a Vara vai, então é uma saída que a gente está vendo pra ela.

Duarte (1994) descreve que família tem um sentido distinto para cada grupo social, sendo que as camadas populares compreendem que família também é formada pelas redes de ajuda mútua comunitária. Apesar dos profissionais que realizam intervenção sobre a família de Valentina reconhecerem que Celeste era a principal figura de vínculo, apoio, com mutualidade na relação com Valentina, ainda assim estavam ancorados na ideia de que seria preferível instaurar uma nova deserção, com a saída de um abrigo para o outro, do que investir no fortalecimento do vínculo entre ambas.

Ainda assim, a equipe não percebe elementos suficientes para trabalhar a reinserção familiar entre ambas. As entrelinhas da narrativa das funcionárias do abrigo, sinalizam que acreditam que as duas juntas não formariam uma família estruturada o suficiente, então não poderiam conceder suporte a essa alternativa.

A conduta cristalizada na atuação dos profissionais do abrigo pode indicar mitos que possuem sobre Valentina e Celeste não serem percebidas como família, ou ao menos não como família suficientemente estruturada e saudável. A ideia estigmatizante de que núcleos de relacionamentos permeados pela circulação de crianças são desorganizados e desestruturados é uma concepção que corre o risco de desprezar múltiplas possibilidades de arranjos sociais que expressam a diversidade dos jeitos ser família, compartilhando o zelo e carinho em sua singularidade, assim como Fonseca (1995) descreveu acerca dos processos dinâmicos da circulação de crianças em Porto Alegre.

O olhar técnico também não sinalizou dificuldade em viabilizar o preconizado na legislação que dispõe sobre o caráter provisório e excepcional do serviço de acolhimento, ao visar a reinserção familiar de crianças e adolescente inseridos em equipamentos de acolhimento. Inclusive a norma a respeito da situação de acolhimento não pressupõe privação de 
liberdade, conforme previsto (art. 101 p. único, Lei 8069/90 - Estatuto da Criança e do Adolescente).

$\mathrm{Na}$ contramão do postulado, Valentina vivenciou situações nas quais sua liberdade de ir e vir foi restringida após ter envolvimentos em situações conflitivas, sem ter autorização para sair do abrigo por determinado marco temporal, o que pode configurar forma de aplicar uma penalidade, como também impor barreira para que a adolescente articulasse formas de se proteger ou expor os excessos do serviço de acolhimento. Por exemplo, a impossibilidade de sair para procurar seu Defensor Público antes de sua audiência, sem permitir que o processo de julgamento tivesse acesso à sua versão dos fatos. Tal versão consta abaixo, de acordo com sua narrativa.

\begin{abstract}
Aí eu perdi a cabeça e fui pra cima dele. Dei um soco na cara dele, mas como ele é muito branquinho, não é negro como eu, ficou super roxo. $O$ pessoal do abrigo levou a gente pra delegacia e fez um BO (Boletim de Ocorrência) contra mim e falaram que vão me levar pra Fundação Casa pra que lá eles decidam o que vai acontecer comigo. Estou com muito medo de ficar presa! Eu falei que aqui eles querem me prejudicar... Quando o moleque quebra meu braço, não fazem nada com ele, quando eu tento me defender de quem está me provocando, eles vêm e fazem isso comigo.
\end{abstract}

O acontecimento relatado acima evidencia o quanto as dinâmicas relacionais inseridas no serviço de acolhimento podem expor a criança ao contrário do objetivo alvo da instituição, ou seja, nesta ocasião não houve proteção, mas sim contato com violências que foram agravadas pelas intervenções institucionais.

A narrativa da jovem torna passível a compreensão de quando Valentina descreve a rua como lugar de diversão, liberdade e leveza. Não se trata de romantizar a rua, ou de apagar as interfaces de vulnerabilidade e sofrimento que por vezes esse ambiente promove. Contudo, na narrativa das crianças, está presente a noção de que habitar às ruas, em distintos momentos de suas vidas, foi a opção mais protetiva disponível.

O que aponta para a necessidade de se reinventar e ressignificar a atuação de muitos equipamentos de acolhimento institucional, para que possam corresponder mais apropriadamente às necessidades da população atendida. Precisões estas que são mais complexas que ter uma estrutura física e arquitetônica para morada e alimentação, mas sim 
ter um ambiente relacional de vínculos permeados de afeto positivo que promovam sentimento de segurança às crianças.

A atividade do poder judiciário durante as oitivas desvelou o quanto o encaminhamento do caso se dá a depender da sorte ou azar da qualidade e disponibilidade de escuta oferecida pelo promotor ou juiz que atenderá a criança. No caso de Valentina o azar entrou em cena e a área da justiça incidiu em novas revitimizações, sem ao menos possibilitar o direito à defesa, por não ter a presença de seu defensor público nas mencionadas oitivas.

Quando chegou a data da oitiva, segundo o relato da Valentina, a mesma ocorreu sem a presença do defensor. Apenas ela, o promotor, a assistente social do abrigo e a diretora do abrigo compareceram. A oitiva teve duração de menos de 5 minutos. O promotor leu o BO que afirmava que ela havia cometido lesão corporal. Ele perguntou se fora isso mesmo o que aconteceu. Ela me relatou que respondeu que ele a estava provocando e que ela perdeu a cabeça e Ihe bateu. Segundo Valentina, o promotor afirmou que não existe isso de perder a cabeça, mas que se ela gosta de ficar perdendo a cabeça, um bom lugar para isso é a Fundação Casa.

Dentre a multidão de injustiças na trajetória da adolescente está a questão dos maus tratos e abandono que foram razões para inserção de Valentina na ciranda entre abrigos. Contudo, quando o serviço de acolhimento restringiu sua liberdade de ir e vir, de ser ouvida, ou até mesmo denunciou e criminalizou seus conflitos relacionais, novamente a violência é revivida. E desta vez, protagonizada por aqueles que se apresentaram como responsáveis por prover segurança social, e por conseguinte, evitar revitimizações.

$\mathrm{Na}$ instituição na qual a pesquisadora do presente trabalho conheceu Valentina e sua família, enquanto psicóloga e educadora terapêutica integrante da equipe a tratativa adotada em situações semelhantes era distinta. Recorrer a polícia não era uma alternativa de acordo com as regras da instituição. No transcorrer de situações de grande estresse, como por exemplo quando discussões desembocavam em heteroagressões e/ou autoagressões, e Valentina se desorganizava, ao ponto de não conseguir estar dentro do abrigo de forma minimamente segura.

Nós saíamos para dar uma volta, dialogando, até que ela encontrava meios de elaborar alguns de seus sentimentos para tranquilizar-se suficientemente, para retornarmos ao 
abrigo. Estas saídas comunicavam até sem palavras que nestas situações de crise os profissionais uniriam esforços para promover a proteção de todos os envolvidos no embate.

Depois o assunto era tratado com a presença das partes envolvidas e de um ou dois profissionais que teriam intervenção de mediação de conflitos, assim como princípios da educação democrática norteiam que sejam utilizadas estratégias pedagógicas para resolucionar problemas relacionais, e dentro do possível investir na restauração dos danos causados na situação de conflito, inclusive danos ao vínculo das partes envolvidas, ao objetivar o melhor convívio possível entre os residentes da instituição.

Situação essa encarada de forma extremamente singular diante do contraste com o protocolo comum em diversos abrigos que lidam com situações acaloradas assim ao lançar mão de recursos como expulsões do envolvidos, por meio de transferência institucional ou da criminalização de crianças. Direcionando aqueles percebidos como algozes do conflito para Fundação Casa, ou mesmo encontrando outras formas de atribuir penalidades, como desprovê-los de passeios ou visita familiar por determinado período. Mais adiante será relatado como algumas dessas práticas revitimizadoras foram adotadas pela instituição na qual Valentina ficou posteriormente, em 2019.

Contingências relativas aos conflitos nas interações sociais podem ser manejadas de forma mais pacificadora por meio das lentes de análise de Pichon-Revière (1998). O autor postulou sobre uma estrutura complexa da dinâmica dos grupos e do deslocamento de papéis dos seus integrantes. Os conhecimentos elaborados destas estratégias de articulação de grupos pode subsidiar profissionais a adotarem um olhar distanciado o suficiente para realizar uma leitura sobre como minimizar os atritos e promover acordos mais prudentes e brandos, ao invés de tomar partido categorizando quem é algoz e vítima em dada situação tensionada, visto que com esse último olhar é provável produzir medidas agravadoras do problema.

Conforme o relato de Valentina, o equipamento de acolhimento também orientou a adolescente a não retornar à escola até as lesões do braço e de sua mão estarem recuperadas, ao justificar que ela não teria condições de escrever as atividades estudantis. Deste modo, Valentina ficou um bimestre sem acompanhar as aulas. O distanciamento 
escolar também incide em fatores que vulnerabilizam a adolescente com prejuízos acadêmicos e sociais.

Quando retomou contato pelas redes sociais, Valentina compartilhou que não estava bem ao ponto de ter tentado se matar. Na sequência, enviou duas fotos, uma na qual estava com o braço engessado, outra mostrando uma grande cicatriz que atravessava o pescoço, horizontal e frontalmente. Assim pediu ajuda.

Tendo em vista que o direito à educação é considerado fundamental (Art. 205, Constituição Federal) é determinante que a escola, a família e a sociedade correspondam ao dever de incentivar, cooperar e garantir que tal direito seja cumprido. Portanto, tanto escola quanto demais atores societários são responsáveis por planejar alternativas de adaptação de material pedagógico e de tarefas escolares para não excluir alunos que tenham alguma necessidade diferenciada, ainda que apenas provisoriamente. Tomar este cuidado poderia evitar esta ruptura adicionada na experiência vivida por Valentina.

Em 2015, Valentina antecipa o processo de reinserção familiar, na instituição em que está intensamente engajada na promoção desse processo. Contundo, na atualidade, estando em uma instituição que não favorece sua reinserção familiar ao lado de Celeste, Valentina apresenta-se passiva e pouco protagonista de sua história.

Malfitano (2008) identificou que quando os adolescentes estão mais próximos de completar a maioridade, isto é, os 18 anos, as evasões institucionais são menos frequentes. Observou-se que neste período de vida, a preocupação e o sentimento de insegurança com a necessidade de ter mais autonomia e independência podem se tornar aspectos motivacionais para que busquem permanecer na instituição de acolhimento. A fim de produzir engajamento para minimizar as incertezas de como será o porvir, por ter proximidade com o momento no qual não poderão mais permanecer no circuito entre abrigos, devido a limitação de sua idade e a escassez de equipamentos socioassistenciais voltados aos jovens adultos.

Embora existam equipamentos de acolhimento para atender a população acima desta idade, o funcionamento é muito diferente, assim como os critérios para ingresso são mais restritos. Por exemplo, o Serviço de Acolhimento em Repúblicas (SAR) implica o envolvimento em atividades profissionais remuneradas, bem como a construção de um 
projeto de vida que possibilite o desacolhimento e a autonomia dos jovens. Tal cenário aponta para as lacunas e desafios da política de proteção aos adolescentes e jovens.

Os pensares desenvolvidos pela citada autora, contribuem para compreensão da razão de Valentina ter, anteriormente, evadido do serviço de acolhimento sem aviso algum quando foi morar com Celeste. Contudo, mais recentemente, mesmo estando em situações significativamente mais aversivas, devido ao risco de sofrer a perda de sua liberdade, ainda ao conviver com o enfrentamento do bullying inclinado à temática sofrível voltada à automutilação, dentre outros fenômenos que não a mobilizaram a buscar outra morada, mesmo tendo a opção de estar com quem gostaria, isto é, com sua mãe, Celeste.

Diante de todos estes aspectos que causaram sofrimento emocional à Valentina é importante considerar que os cuidados direcionados a sua saúde mental, inclusive por conta do quadro com sintomas de depressão, ideação suicida, automutilação e impulsividade eram direcionados para tratamento no CAPSi para prescrição de medicação psiquiátrica mensal e na UBS para psicoterapia também mensal, por conta da indisponibilidade de vagas para realizar atendimento psicológico intensivo. Portanto, a falta de recursos e estrutura da rede de serviços de saúde não oferece o acompanhamento imperativo à saúde biopsicossocial da adolescente.

Um novo acontecimento intensificou ainda mais as angústias vivenciadas por Valentina, conforme relatou a seguir.

Tia, vão fazer outro BO contra mim. É difícil de explicar... Aconteceu umas coisas lá no SAICA... uma brincadeira, mas aí eu estou levando a culpa, é difícil explicar. Preciso de algum advogado, você pode me ajudar, tia? É que eu estava brincando no quarto do abrigo com as meninas minhas amigas. Tinha mais três meninas comigo. A gente teve uma ideia de a gente fazer marca de chupão (beijo succionado) no pescoço da gente, pra causar e parecer que a gente está ficando com os moleques. Daí depois os tios do abrigo viram o chupão no pescoço da menina mais nova, ela tem 10 anos, e perguntaram pra ela quem foi e ela falou que fui eu, contou que era brincadeira. Mas os tios fizeram BO contra mim de estupro de criança.

A temática da sexualidade emergida nesta ocasião revelou que a equipe profissional do serviço de acolhimento interpretou que houve estupro devido a diferença etária entre 
Valentina e a garota de 10 anos, o que ressalta o despreparo técnico para lidar com o assunto sexualidade nas instituições de acolhimento. Além disso, denota o perfil autoritário e punidor de membros da equipe institucional que não proporciona lugar de escuta ativa e afetiva para ouvir as crianças e conhecer mais sobre as suas relações, brincadeiras e noções de consentimento, que podem ser divergentes da perspectiva externa e distanciada do julgamento adultizado.

Outra coisa foi que as meninas pediram pra experimentar meu remédio do psiquiatra porque elas tinham curiosidade de ver se dava alguma brisa legal, e eu deixei, cada uma pegou um e tomou. Os tios ficaram sabendo. Ai tia, me ajuda por favor... Eu nem sei quem contou tudo pra eles, mas eles colocaram no BO que eu queria deixar uma criança drogada e estupra (sic) uma criança também. Não foi nada disso e agora eu posso ir ficar atrás das grades por causa de uma brincadeira de amigas. E minha mãe nem vai poder me visitar porque nem é da família.

Apesar das lacunas e nós da tessitura da rede de garantia de direitos, Valentina não teve passagem pela Fundação Casa e completou seus 18 anos morando com Celeste, após reinserção familiar militada com perseverança por ambas, a despeito dos relevantes obstáculos e da discordância do corpo técnico institucional.

No trânsito entre abrigos e ruas, portanto, Valentina vivenciou a reinserção familiar em três momentos de sua vida, primeiro quando tinha 8 anos e voltou a morar com sua família consanguínea, depois aos 15 ao morar com Celeste, sua mãe por consideração e, atualmente, após ter saído da última instituição de acolhimento pela qual passou, para retornar à casa de Celeste.

\subsection{Concepções de família para Valentina, Celeste e profissionais}

A relação entre Valentina e Celeste indica que ambas atribuem o sentido de ser família a interação que transcende à conexão biológica, ao ponto do vínculo com Celeste ser uma referencial parental para Valentina que supera em demasia a ligação que possui com sua irmã primogênita, dentre demais parentes. 
O afeto, a consistência de presença compartilhada, o suporte concedido em situações de dificuldades materiais ou emocionais, a habilidade de ressignificar e reparar danos provenientes de problemáticas são elementos constitutivos do relacionamento familiar desfrutado por ambas, mãe e filha. Conforme postulado por Bowlby (1997) sobre a importância de reparar prejuízos ao vínculo, a fim de possibilitar a superação de angústias que impactam a saúde mental da criança.

Diferentemente da noção de família sinalizada pelos profissionais que as atenderam no serviço de acolhimento, que demonstraram priorizar o vínculo consanguíneo em detrimento de vínculos de coração. Além de terem sinalizando superestimar que o vínculo familiar precisa contribuir para a construção de um grupo parental bem enquadrado na normatização social, onde o papel de autoridade do adulto e de subserviência da criança seja bem demarcado.

A equipe institucional revelou em sua atuação que o processo de reinserção familiar tem apoio institucional restringido aos casos nos quais o modelo de família corresponde a visão estereotipada que adotaram, permeada pelo preconceito que não aceita a diversidade dos modos de ser no mundo e nas interações, mas sim assume a perspectiva de família idealizada, com papéis rígidos, delimitados, não fluídos com plurais jeitos de viver e ser.

\subsection{Netos de Hilda entre reinserções e deserções}

Os netos de Hilda compõem um grupo de quatro irmãos, com faixa etária entre 7 e 12 anos de idade. Viveram em situação de rua contando com a presença materna e testemunharam impactantes violências, inclusive a situação onde a mãe quase veio a falecer. A mãe habita as ruas e faz uso radical de substâncias psicoativas.

A reinserção familiar foi protagonizada pela mãe que desacolheu as crianças às escondidas, aproveitando um passeio com os filhos que foi autorizado pelo abrigo para não retornar mais. Período relatado pelas crianças com marcos de altos e baixos, entre aventuras, diversão, proximidade de relações, e por outro lado ficaram as marcas dos traumas, violências e sofrimentos vivenciados. 
No momento estão acolhidos e possuem como principal vínculo a avó biológica Hilda. Visitam-na aos finais de semana e desejam morar com ela, embora isso ainda não possa ocorrer por conta dos riscos que da vizinhança e interferências de Sandra, a mãe das crianças. Sandra, inclusive, levou a filha caçula, Dani, para morar consigo nas ruas, conforme histórico anterior, também o fez às escondidas, sem comunicar a ninguém e assim permaneceram juntas nos últimos 3 meses.

Mais uma deserção para história de Dani que estava ao lado dos irmãos e da avó e não era privada da companhia da mãe, pois frequentemente a encontra nas visitas ao serviço de acolhimento ou na casa da avó. Porém, no tempo presente está distanciada desses laços afetivos, e provavelmente está exposta a riscos e violências, para além da violação ao direito à convivência entre irmãos.

Direito este que poderia ter sido descumprido pela instituição de acolhimento também, pois a diretora do abrigo atual propôs que Hilda deixasse Dani disponível para adoção, devido a sua idade ser interessante para pais que procuram adotar uma criança. Mas a avó Hilda destacou que Dani possui família e que o lugar adequado para ela é junto de sua família e irmãos.

Família é todo conjunto de pessoas unidas por interações sociais com certo grau de coesão entre seus membros, com graus de parentesco artificiais ou concretos, declarados ou ocultos, com ou sem ligação genética. (RAMOS, 2011, p.02)

Paradoxalmente, a diretora realizou proposta supostamente por refletir no que seria benéfico para Dani. De modo ambivalente, pela perspectiva de Sandra, provavelmente, houve uma nova reinserção, na qual ela pode estar mais conectada com a sua filha, sem interdições e barreiras institucionais para fazer ponte entre a relação de mãe e filha. Então, processos de reinserção e deserção podem ser compreendidos de formas distintas de acordo com o ator social que observa tal fenômeno. Isto ocorre devido às múltiplas dimensões que perpassam as relações familiares.

A dimensão do papel desempenhado por Hilda junto aos netos é marcada por cuidados maternais mais frequentes que os cuidados exercidos pela própria mãe biológica das crianças. A consistência do vínculo de Hilda com os netos a faz considerar trazê-los para morar consigo. Todavia, percebe que na atualidade há barreiras que a impossibilitam. 
Ademais das limitações financeiras, há o problema da vulnerabilidade e violência que circundam a periferia na qual reside, sendo que a violência aparece tanto com 0 protagonismo de integrantes do tráfico de psicotrópicos (ZALUAR, 2004), quanto com o Estado através da polícia, em concordância com a declaração de Hilda a seguir.

Fora que não tem horário para ROCAM (Ronda Ostensiva com Apoio de Motocicletas) entrar aqui com tudo. Tem polícia que eles entram e bate (sic), pega (sic) menor... E só não entram dando tiro porque a população já está avisada. Prefiro levar eles pro abrigo do que esperar pra ver onde isso vai dar. Fora que no abrigo eles tem café da manhã, almoço, lanchinho da tarde, janta, outro lanchinho da noite... E aqui não é assim, não. A gente come todo dia, eu me esforço pra trabalhar e ter sempre o pão, mas aqui nós não come igual eles estão acostumados no abrigo. Marcos está uma tora! Eles comem bem. Lá eles têm luxo que não tem aqui.

As violências ressaltadas pelo discurso de Hilda são estas que estão ao redor de sua casa, e nos permite refletir sobre morar nas ruas como forma de exposição às vulnerabilidades, bem como morar na periferia pode ser experienciado de semelhante modo, diante da presença do tráfico buscando aliciar crianças e adolescentes, bem como a avó discorre sobre as particularidades das violências cotidianas do território, inclusive estatais caracterizadas pela truculência policial.

A rua possui dimensões plurais, desde os prédios de ocupação no Centro da cidade, até o entorno dos becos e vielas da periferia urbana, aponta como diferentes locais pelos quais as crianças viveram são dotados de predicados muitos similares, de habitação desprotegida, vulnerável, instável e sujeita às multíplices violências.

Adorno (1999) pontua sobre como a falta de espaços de lazer e cultura limita o repertório de possibilidades de diversão para crianças na periferia do território da cidade. O lazer na atualidade é perpassado pela tecnologia, através do uso de eletrônicos como redes sociais e vídeo games. As crianças passavam horas cada uma fixada na sua tela enquanto estavam na casa da avó, conectados virtualmente com relações externas à família, enquanto interagiam mais entre si durante as vivências pelo bairro, empinando pipa ou indo ao parque da creche usar seus equipamentos (balanço, escorregador...) ou jogar futebol. 
Enquanto brincam, as crianças se divertem, contudo, Marcos é o irmão que insultar os demais com alta frequência, até mesmo durante atividades lúdicas. A avó Hilda verbalizou que analisa esta característica comportamental enquanto problema associado ao fato de Marcos ser, justamente, o filho de Sandra que a estava segurando em seus braços enquanto ela estava desacordada, com intensas hemorragias pelo corpo após ter sido agredida, "Um dia a psicóloga perguntou pro Marcos: "Do que você tem medo?". Ele respondeu: "Da minha mãe morrer".

O temor de Marcos indica a pertinência da sensível leitura psicoemocional que a avó realiza, que inclusive poderia ser feita de semelhante forma pela equipe de profissionais do serviço de acolhimento. Os comportamentos de agressividade e de conflito dentro do abrigo, devem ser analisados como a ponta do iceberg visível, associada aos conteúdos invisibilizados do sofrimento. Isso somente é possível ao se considerar fatores emocionais e psicológicos da trajetória da criança. Tal análise permite intervir de modo mais acurado ao fazer gestão de situações conflitivas de modo respeitoso, pautado na perspectiva de quem usa lentes que enxergam para além da superfície dos fatos.

A agressividade foi observada por Hilda também nos demais irmãos, sobretudo quando as crianças chegaram a sua casa, após terem ficado por mais de um ano nas ruas com Sandra, estavam com posturas de forte rispidez. FASSIN (1998) estuda as relações entre a saúde e as relações com o espaço social, o que permite pensar sobre a necessidade de cuidados à saúde mental de pessoas em situação de rua, sob uma ótica que transcenda o reducionismo da medicalização do sofrimento, ao levar em consideração o impacto das vivências de vulnerabilidade para a saúde biopsicossocial.

Esclareceu que quando deixava as crianças em casa, os conflitos entre eles eram tão críticos que os vizinhos, preocupados, vinham procurá-la para contar o que havia acontecido na sua ausência. Um tentou se jogar pela janela com cerca de dois metros de altura, mas os vizinhos interviram. Outro começou a sair de casa para andar com pessoas que aliciavam garotos para o tráfico. Outro usou uma faca de casa para causar agressões em um conflito que tiveram. Dentre outros motivos relatados pela avó.

No decorrer do tempo com as crianças inseridas em ambiente que ofereceu contorno por intermédio do acolhimento e da proteção, os comportamentos agressivos reduziram admiravelmente. $O$ que permite refletir sobre $o$ quanto $o$ temperamento e padrões 
comportamentais podem ser influenciadas pelo ambiente de convívio das crianças, conectadas por fatores como a insegurança e a hostilidade circunstancial, bem como, em contrapartida, pelo afeto e cuidado.

Uma alternativa para proteger as crianças das vulnerabilidades manifestadas no bairro de Hilda foi considerada pela diretora do abrigo, ao cogitar matricular as crianças no equipamento CCA como alternativa para que elas voltassem a morar com a avó, mas ficassem resguardadas dos riscos atrelados ao bairro, visto que estariam neste CCA durante o contra turno escolar, por conseguinte estariam em espaços educacionais em período integral, enquanto a avó estivava trabalhando.

ADORNO (et al., 2008) postula sobre o enfoque do Estado em produzir políticas públicas com intervenções focais, diante da dificuldade de abranger todas as necessidades de um contingente populacional extenso que se encontra em situação de vulnerabilidade social. Deste modo, o CCA é um equipamento socioassistencial que atende algumas lacunas na construção políticas públicas para infância.

Tal serviço institucional evidencia a relevância da oferta diversificada de aparelhos de assistência social para suprir as demandas comunitárias. Apesar da insuficiência de resultados do esforço na direção do serviço de acolhimento para viabilizar a articulação desta estratégia que foi pensada diante das preocupações com as interferências de Sandra, devido ao seu histórico de causar infortúnios quando as crianças estão mais acessíveis ao seu contato, residindo com Hilda.

Meus amigos vizinhos até me falavam: "Não adianta você fazer pelos meninos enquanto a Sandra está estragando". Sabe aquela pessoa que fica agressiva pedindo dinheiro pra droga? Às vezes ela chegava em casa tão transtornada que chegava a espumar a boca. $E$ as crianças vendo aquilo. Aí eu estava chegando da escola com o Marcos e ela estava com um menino da idade dele usando droga na rua, aí ele via e falava pra ela: "dá licença que a sua turma é aquela lá, apontava pra galera usando droga.

As palavras de Marcos apontam para uma ruptura na relação com sua mãe. Dentre as vivências de rupturas e deserções estão as experiências que as crianças tiveram durante a intensa rotativa entre abrigos até ser providenciada vaga próxima à residência de Hilda. $\mathrm{O}$ trânsito institucional das crianças que já possuem uma história de vida de rupturas de 
vínculos pode proporcionar maior dificuldade de desenvolver habilidades sociais de afeto e pertencimento, diante das frustrações advindas de rupturas consecutivas.

A escola de Luan pode ser apontada como fator de proteção em suas experiências, pois por sua vez, teve papel importante para auxiliá-lo a conectar-se com novos relacionamentos, presumivelmente contribuindo na ressignificação do padrão de rupturas e deserções nos laços afetivos, pois Luan reforça o quanto gosta de seus professores e amigos da escola, sublinhando que têm docentes que Ihe ajudam com conversas que extrapolam os limites dos conteúdos pedagógicos das disciplinas, mas abordam questões relacionais e emocionais com aconselhamentos construtivos que são próprios de uma relação de confiança e referência afetiva.

A experiência de Luan parece ser de pertencimento e afinidade também com os profissionais do serviço de acolhimento, embora tenha colocado foco sobre os aspectos afetivos dos relacionamentos escolares de forma mais significativa. De semelhante modo, as demais crianças também verbalizaram ter boas relações com a equipe técnica do equipamento assistencial, conquanto não compartilharam sobre as relações escolares com o mesmo entusiasmo que Luan.

No ambiente do abrigo, houve um acontecimento que desestabilizou alguns relacionamentos de Luan e seu sentimento de segurança dentro da instituição. Não em decorrência do convívio com outros acolhidos ou com equipe, mas devido ao um desentendimento delicado com a família de uma criança, em concordância com o subcitado relato de Hilda.

O Luan está desde quinta-feira aqui, né? Os outros chegam sábado. Ele está desde quinta porque tem um casal de usuário de drogas (sic) que são pais de uma menina lá do abrigo, que disse que o Luan mexeu na parte intima dela, e ela contou pra mãe. A mãe ouviu e disse que já voltava. Quando voltou trouxe um monte de moleque pra bater no Luan. Luan disse que não fez nada. Daí a diretora do abrigo não acredita que tenha acontecido isso, mas como estão querendo fazer mal pra ele, mandaram ele pra cá pra casa pra esperar baixar a poeira lá..

Diferentemente da conduta tomada por profissionais que cercavam Valentina, neste cenário, Luan contava com a credibilidade e apoio da equipe e das crianças que o 
conheciam, pois não consideravam que a acusação tivesse qualquer veracidade. Então, medidas foram aplicadas por meio do diálogo para buscar a resolução pacífica do problema, sem provocar desdobramentos criminalizadores e agravadores do panorama, conforme detalhado no diário de campo.

As expressões de sexualidade no ambiente de acolhimento institucional refletem em demasia a forma como a sociedade lida com tal tema, ou seja, como um tabu, permeado de não-ditos. A sexualidade também é temática pouco estudada pelos profissionais do equipamento de acolhimento, consequentemente, há escassez de inspirações teóricas e técnicas de como manejar situações difíceis que envolvem tal assunto no contexto institucional (MELO, 2009).

Neste quesito é trivial que mesmo nas instituições consideradas referência no acolhimento a equipe tenha incertezas quanto a quais procedimentos utilizar para gerenciar conflitos tangenciado à questão da sexualidade. Inclusive quando Luan estava sendo acusado de abuso sexual contra uma criança, relembrou com falas indignadas os comportamentos de Paulo de 16 anos, do abrigo no qual conheceu a autora da presente pesquisa, onde Paulo praticava atos erotizados com crianças a partir de 6 anos de idade, contexto no qual a equipe parecia sentir-se desnorteada de como intervir. Isto sem aprofundar a problemática corriqueira da dificuldade em lidar com a erotização precoce de crianças no âmbito do acolhimento socioassistencial.

A supervisão de equipe realizada por supervisor externo, que, portanto, não estava imerso nas problemáticas da casa de acolhimento como os profissionais que atuavam no interior do serviço, era o mecanismo que colaborava com a compreensão e direcionamento de contingências nebulosas do caso que envolvia Paulo. Contudo, supervisão institucional é um recurso muito raro de ser acionado nas instituições de acolhimento, em linhas gerais.

Em meio aos conflitos envolvendo Luan, Hilda também faz referência a sua relação pessoal com o abrigo como sendo muito positiva, embora ressalte que não tem o mesmo suporte que recebia da instituição na qual conheceu a pesquisadora, onde a equipe auxiliava com doação de alimentos ao finais de semana que as crianças ficam em sua casa, o que não ocorre na instituição presente. 
Contudo, declara que seus principais desapontamentos são com o Conselho Tutelar porque ora desempenhou papel de acolhimento e suporte com direcionamento sobre a possibilidade de acolhimento institucional quando se tornou inviável para ela cuidar das crianças. Noutro contexto, outro CT adotou função de acusador, deixando sobre Hilda a responsabilidade pelas crianças, mesmo no cenário desfavorável para que os netos morassem consigo, ao insinuar que ela estaria sendo negligente por não cuidar de sua família.

A avó também delineou a frustração concernente ao vínculo institucional estabelecido com suas crianças, que sofreu a substituição de toda a equipe profissional do abrigo que possuía longa experiência no campo da assistência social de alta complexidade, substituída por outra equipe muito menos experiente, com uma ruptura abrupta do vínculo de cerca de sete anos de relações entre profissionais, crianças e famílias, fenômeno que perfez uma deserção adicional para a vivência das crianças. Hilda ainda explicitou o seguinte:

Lá estava uma bagunça, tanto que o Ministério Público mandou fechar de tanta criança que fugia e de coisa errada que acontecia lá. Tanto que quando a Sandra levou as crianças, o pessoal nem me avisou. Foi quando eu fui visitar que fiquei sabendo do que aconteceu. E depois disso, eles fizeram um Boletim de Ocorrência de desaparecimento dizendo que fazia três dias, mas não duvido que pode ter sido muito mais tempo. Essa equipe parecia que, pra turma que eles pegaram, eles estavam muito despreparados. Parece que estavam investigando, parecia que eles estavam desfocando dinheiro, verba, não sei. Eu não botei firmeza neles.

O Ministério Público e o CREAS, paradoxalmente, são responsáveis pela fiscalização dos serviços de acolhimento institucional. Sendo que tal deserção suprarelatada foi protagonizada pelo CREAS que operacionalizou a alteração da equipe de acolhimento. Tanto o Estado quanto a família, portanto, imprimiram processos de deserções e rupturas nas vivências destas crianças.

\subsection{Concepções de família para Hilda, crianças e profissionais}

Apesar dos episódios pregressos entre desenlaces e distanciamentos causados pelos conflitos associados ao radical consumo de psicotrópicos por Sandra, ou pelas 
contingências socioeconômicas de Hilda que influenciaram certo grau de afastamento. Sobretudo o engajamento afetivo na rede de relacionamentos parentais tornou os reencontros tão recorrentes que foram imprescindíveis para sustentar esta conexão familiar.

A busca pelo reencontro, o estar juntos, independentemente das adversidades e discordâncias são características que fortalecem as relações parentais nesta família e que definem a concepção de família que expressam em suas histórias. A presença é afetiva e por vezes conflitiva, todavia esses conflitos não são comparáveis ao sofrimento e angústia resultantes das rupturas que já vivenciaram, até mesmo diante do sentimento expressado pelas crianças e avó diante da ausência de Dani.

A orientação da diretora do abrigo para que Dani fosse adotada possivelmente aponta à concepção de família enquanto espaço de ausência, de escassez material e inexistência de problemáticas complexas como uso radical de substâncias psicoativas pela figura materna ou sem contato com dificuldades econômicas semelhantes aquelas vivenciadas por Hilda.

Outra hipótese consiste na falta de credibilidade que a diretora atribuiu aos rumos do futuro deste grupo familiar, por isso retirar Dani de sua família e inseri-la noutra poderia ser notado como oportunidade mais protegida para sua trajetória. Novamente sinaliza-se a percepção normatizadora de família estruturada e idealizada, de acordo com a conduta da citada diretora

Apesar de tal inclinação para provocar deserção com ruptura da integração entre o grupo de irmãos devido a apresentação da sugestão de adoção de uma integrante do grupo parental, inclusive com certa insistência, por fim no desfecho da questão respeitaram a recusa manifestada pela avó, e deram continuidade nas ações de fortalecimento do relacionamento familiar, sobretudo através da rotina de visitas das crianças à avó, fator este que possibilitou as crianças manterem a conexão com a casa onde viveram e comunidade de seu território de origem.

Assim tal serviço de acolhimento investe no reforçamento do senso de pertencimento, por viabilizar às crianças estar entre familiares e amigos dos bairro com os quais compartilham gostos, assim como permite partilhar da tradição, da forma de comunicação, dentre outros hábitos e costumes que são aspectos culturais importantes para se sentirem inseridos em um grupo social relevante de suas identidades e trajetórias existenciais. 


\section{CONSIDERAÇÕES FINAIS}

A estrutura e o funcionamento das instituições de acolhimento são formados por pessoas e suas relações entre profissionais e o público atendido. A performance de cada pessoa da equipe de acolhimento institucional tem sua contribuição para caracterizar o desempenho do serviço entre a extensão de suas possibilidades e de seus desafios. Estas pessoas são providas de certo perfil, personalidade, saberes, desconhecimentos, preconceitos, condutas, morais e valores que perpassam a sua atuação e qualificam a identidade da instituição.

Este conjunto de elementos que a pessoa que representa a instituição carrega em si, pode promover potência, afeto, transformação e integração social que serão importantes no processo de formação das crianças. Em contrapartida, um conjunto com elementos diferentes, como autoritarismo, rigidez, intolerância a alteridade, pode perfazer uma somatória que produz revitimização, violência, estigmatização, sofrimento, fragilidade e deserção social influenciada pela atuação institucional.

Na observação de campo constatou-se que os processos históricos de cunho policialesco e normatizador das primeiras instituições de acolhimento do Brasil ainda transmite heranças transgeracionais nas práticas desenvolvidas nos equipamentos de acolhimento da assistência social.

O corpo técnico institucional não somente é produtor de política pública, mas também é produzido por ela, dentro dos desafios e limites dos recursos disponibilizados para estrutura e funcionamento institucional. Bem como, são influenciadores da sociedade, porém também são influenciados pelos sistemas normativos e de valores que permeiam a cultura e engrenagens sociais. Tal reflexão é necessária para compreender que não trata-se de responsabilizar a equipe pelas dificuldades que tangenciam o serviço de cuidado socioassistencial, visto que é complexo os elementos envolvidos no árduo caminho para edificar transformações institucionais.

Inclusive é indispensável considerar a gravidade de que os cuidadores não são cuidados, isto é, não há fácil acesso aos recursos de formação e qualificação de profissionais do 
acolhimento para que possam refinar seus conhecimentos e lapidar o desempenho de suas atuações, suas concepções de família e norteadores para a reinserção familiar de crianças.

O que é inserção familiar? O que é deserção familiar? A pergunta ecoa sem respostas completas, contudo, com as pistas apresentadas pelas crianças e suas famílias é notável que o processo de inserção e a deserção familiar consiste em uma trajetória cíclica na vida de diversas crianças que habitam as ruas e as instituições de acolhimento.

A inserção familiar detém dimensão simbólica, abstrata, psicoemocional, que está mais associada à qualidade afetiva e força de sustentação dos relacionamentos mais próximos e relevantes ao convívio do indivíduo, seja familiar ou comunitário, do que propriamente do lugar concreto e físico no qual a família está situada. Enquanto a vivência da deserção é percebida pela descontinuidade e interrupção dessas interações parentais.

A inserção familiar indicou estar centrada no sentimento de pertencimento e segurança onde há disponibilidade para superar as adversidades através da fluidez relacional que contribui à ressignificação dos laços afetivos. Ao conceber que tensões e atritos são inerentes às relações grupais, contudo existe uma gama de estratégias de gestão de conflitos relacionais que não lançam mão da quebra do vínculo, mas sim busca reparar rasgos da tessitura de relacionamentos significativos.

O serviço de acolhimento pode ser um lugar onde a realidade de cuidado às alianças invisíveis dos relacionamentos e fortalecimento dos vínculos está acessível. No entanto diante da narrativa das crianças e de suas famílias, é perceptível que o oposto também é verídico e muito frequente. Nas suas narrativas o serviço de acolhimentos ora se posicionou como ponte de facilitação aos contatos familiares, ora como barreira e impedimento para o mesmo fim.

A qualificação profissional do serviço de acolhimento que prioriza a atenção aos vínculos estabelecidos nos diversificadas direções: da equipe para com as crianças, da equipe para com as famílias, das famílias para com as crianças e vice-versa, ocorre quando a equipe busca usar intervenções para fortalecer os laços relacionais, com finalidade de promover acolhimento que é possível ao priorizar relacionamentos e ter expertise instrumental sobre o desenvolvimento humano e as interfaces dos vínculos. 
Além da formação continuada dos profissionais, também é fundamental a construção de uma rede de serviços que corresponda às necessidades da sociedade. Entretanto, há escassez de alternativas de atendimento para jovens que concluem os 18 anos de idade. Portanto, investigar organizações e projetos nacionais e internacionais que estão voltados a construção de instituições de acolhimento e cuidado para esta faixa etária, pode ser um caminho importante para construção de novos espaços que correspondam às demandas desta população por acolhimento e por desenvolvimento de autonomia, o que pode oportunizar a efetiva preparação de jovens para o mundo adulto que demanda certo corte do cordão umbilical com o pai Estado.

A formação profissional aos técnicos do serviço de acolhimento pode ser enriquecida ao tratar dos princípios da comunicação não violenta como plataforma para lidar com a gestão de conflitos de modo efetivo (Rosenberg, 2006). Assim como é relevante envolver investimentos de qualificação dos técnicos sobre a temática da reinserção familiar, e também da sexualidade para compreensão de como manejar situações para colaborarem ao desenvolvimento saudável da criança e do adolescente, de forma pautada em conhecimento científico, não norteada pelo senso comum, estereótipos e preconceitos dos quais os profissionais não estão ilesos.

A qualificação dos profissionais também carece de ser instrumentalizada para lidar com as demandas de saúde mental, diante da temática do suicídio, automutilação, dentre outras que não são devidamente acompanhadas pela rede de saúde, devido a escassez de vagas. Portanto, o psicólogo do serviço de acolhimento pode contribuir com projetos e ações que visem, dentro do possível, contrabalançar a falta de tratamento adequado, por exemplo, por meio de grupos de fala, dentre demais opções de intervenções de cuidado.

O cuidado oferecido aos profissionais por meio de formação continuada deve ocorrer em articulação com a fiscalização do serviço que observe normas e critérios fundamentais para o funcionamento apropriado da instituição, conforme as diretrizes do edital de para conveniamento desta modalidade de serviços, bem como em consonância com o arcabouço de normas técnicas oriundas da Secretaria Municipal de Assistência e Desenvolvimento Social - SMADS.

Destaca-se que a prescrição para conveniamento é concernente ao conjunto de normas técnicas são pequena parte do conhecimento necessário para o desejável funcionamento do serviço de acolhimento, pois o conhecimento que tornará o trabalho diferenciado 
consiste em apropriar-se sobre as ciências do desenvolvimento humano, construção de autonomia, educação infatojuvenil, teoria do vínculo e reparação, bem como inspirações em experiências enriquecedoras, como a de Summerhill e da Casa das Expedições. ${ }^{11}$

A gestão de conflitos também consiste em assunto que revela o desconhecimento dos profissionais do equipamento assistencial sobre formas eficazes, pautadas em estratégias e métodos que proporcionam lidar com os desentendimentos grupais de forma não-violenta, tampouco criminalizadora.

As reflexões resultantes da pesquisa indicam a imprescindibilidade da prática de prevenção ao acolhimento institucional, a partir da elaboração de recursos, ou até mesmo equipamentos socioassistenciais, inclinado a ações com visitas domiciliares às famílias em situação de vulnerabilidade socioeconômica, para realização de estreito acompanhamento familiar, longitudinal, com intuito canalizar recursos matérias e humanos, a fim de evitar que cenários se tornem agravados e alcancem a necessidade de deserção familiar de crianças, por intermédio do equipamento institucional.

Visto que a pobreza não deve incidir em motivo para o acolhimento institucional, contudo, a pesquisa mostrou o quanto as violências presentes nos bairros periféricos, são questões adjacentes à pobreza que podem resultar na institucionalização de crianças para protegêlas dos riscos do território no qual sua família vive.

Possivelmente equipes do CRAS e CREAS poderiam implantar um novo modelo de equipamento social, instrumentalizados para adotar maior engajamento em atender famílias em condição de risco social, podendo deste modo conhecer necessidades importantes e intervir sobre elas, de antemão, com objetivo central de causar o evitamento da institucionalização de crianças.

Assim como em Portugal alcançou-se tal patamar de prevenção ao acolhimento institucional de crianças, conforme breve relato do intercâmbio profissional que permitiu reconhecer o quanto as nomenclaturas escolhidas para o discurso das Políticas Públicas viabiliza interferir na atuação e eficácia dos serviços socioassistenciais, bem como pode potencializar o engajamento social no cuidado de crianças em articulação com o sistema de

\footnotetext{
${ }^{11}$ Summerhill School é a mais famosa e antiga escola democrática do mundo situada no Reino Unido (Neill, 1975). A Casa das Expedições é a instituição de acolhimento de São Paulo, considerada referência por sua atuação transformadora e singular (Portal Fazendo História, 2018).
} 
garantia de direitos. Portanto, rever e repensar os termos adotados no campo do acolhimento infatojuvenil pode influenciar, positivamente, a experiência brasileira frente a tal fenômeno.

Por fim, o ponto acerca da rotatividade de crianças entre serviços de acolhimento demanda ser repensado e reestruturado, pois estas crianças já possuem histórias de vida de rupturas relacionais, então quando o equipamento socioassistencial reproduz este modelo em um ciclo de vinculações e desvinculações com espaços e equipes, esta dificuldade de construir vínculos saudáveis pode ser agravada.

Os apontamentos colocados indicam assuntos que são ricas possibilidades de continuidade de pesquisas no âmbito das políticas públicas sociais inclinadas à infância e adolescência, embasadas no engajamento pelo entendimento de práticas aplicáveis que potencializem a garantia dos direitos infatojuvenis no Brasil. 


\section{REFERÊNCIAS BIBLIOGRÁFICAS}

ADORNO, R. C. F. "Nem trabalho nem lazer: a rua como ameaça e atração na vida de crianças e jovens das classes populares". In: WESTPHAL, M. F.; CARICARI, A. M.; CAMARGO, M. T. V. E. F. O compromisso da saúde no campo do trabalho infantojuvenil: uma proposta de atuação. São Paulo : USP/FSP, 1999, pp. 87-97.

e SILVA, S. L. "Cenas do mapeamento da rua: diários e discussões dos educadores". In: LESCHER, A. D. et al. In: Cartografia de uma rede. São Paulo : Projeto Quixote, UNIFESP, FSP/USP, UNCDP, Ministério da Saúde, 1999, pp.9-32.

Alvarenga AT \& Vasconcelos, MPC (organizadores). Jovens, trajetórias, masculinidades e direitos. São Paulo: Fapesp/Edusp. 2005. p. 296 312.

\& SILVA et al. Cartografia de uma rede - Reflexões sobre um mapeamento da circulação de crianças e adolescentes em situação de rua da cidade de São Paulo, 1998.

ANJOS, Fellipe dos. Poesia: Infância e Amor. Disponível em: https://www.instagram.com/p/B15M58PBU5U/ - Acesso 03 de setembro de 2019.

ARIÈS, Phillipe. História Social da Criança e da Família. Ed. LTC, 1981.

AZÔR, A. M. G. C., \& Vectore, C. (2008). Abrigar/desabrigar: Conhecendo o papel das famílias nesse processo. Estudos de Psicologia (Campinas), 25(1), 77-89. doi:10.1590/S0103--166X2008000100008.

BADINTER, Elisabeth. Um amor conquistado: o mito do amor materno. Rio de Janeiro, Nova Fronteira, 1985.

BEAUD, Stéphane. 2018. "El uso de la entrevista em las ciências sociales. Em defensa de la 'entrevista etnográfica'”. Revista Colombiana de Antropologia, v.54, n.1: 175-218.

BÍBLIA Sagrada. Trad. João F. de Almeida. Versão atualizada. Disponível em: . Acesso em 4 jun. 2019. 
BOWLBY, J. Formação e Rompimento dos laços afetivos. São Paulo: Martins Fontes; 1997.

BRASIL. Estatuto da Criança e do Adolescente. Lei no 8.069, de 13/07/1990: Constituição e Legislação relacionada. São Paulo: Cortez; 1991.

- Lei no 12.010, de 29 de Julho de 2009. (2009, 04 ago.). Dispõe sobre adoção; altera as Leis ${ }^{\text {os }} 8.069$, de 13 de julho de 1990.

- Código Civil, e da Consolidação das Leis do Trabalho - CLT, aprovada pelo Decreto-Lei $n^{\circ} 5.452$, de $1^{\circ}$ de maio de 1943; e dá outras providências. Diário Oficial da União. Recuperado em 06 de setembro de 2010, de http://www.planalto.gov.br

- Ministério do Desenvolvimento Social e Combate à Fome. Plano Nacional de Promoção, Proteção e Defesa do Direito de Crianças e Adolescentes à Convivência Familiar e Comunitária. Brasília: CNAS; 2006. Disponível em: http://www.mp.rs.gov.br/areas/infancia/arquivos/planonacional.pdf.

- Plano Nacional de Enfrentamento da Violência Sexual contra Crianças e Adolescentes. Brasília: autores, (2000). Disponível em: http://www.crianca.mppr.mp.br/arquivos/File/publi/sedh/08 2013 pnevsca.pdf (2011). Primeira Pesquisa Censitária Nacional sobre Crianças e Adolescentes em Situação de Rua. Disponível em: http://www.teleios.com.br/wpcontent/uploads/2011/03/Pesquisa-Censitaria-Nacional-sobre-Criancas-e-Adolescentes-emSituacao-de-Rua-Mar-2011.pdf CASTEL, R. As metamorfoses da questão social. Petrópolis: Vozes, 1998.

CAVALCANTE, L. I. C., COSTA, S. S.; MAGALHÃES, C. M. C. (2010). Institucionalização e reinserção familiar de crianças e adolescentes. Revista Mal-Estar \& Subjetividad, 10(4), 1147-1172. Recuperado em http://pepsic.bvsalud. org/scielo.php?script=sci_arttext\&pid=S1518--61482010000400005\&lng=pt\&nrm=isso. 
CONFEDERAÇÃO SUIÇA. Código Penal Reformado, 2004.

CONSELHO NACIONAL DO MINISTÉRIO PÚBLICO. Ação integrada. CNMP, CNJ e MDS estudam a unificação de dados sobre abrigos para crianças e adolescentes. Disponível em: http://www.cnmp.gov.br/portal/index.php?option=com content\&view=article\&id=1834:acaointegrada\&Itemid=146. Acesso em: 11 mar. 2013.

CONSELHO NACIONAL DOS DIREITOS DA CRIANÇA E DO ADOLESCENTE (Conanda). Conselho Nacional de Assistência Social (CNAS). Orientações Técnicas para os Serviços de Acolhimento para Crianças e Adolescentes. Brasília: Conanda, CNAS; 2008.

CONSTITUIÇÃO DA REPÚBLICA FEDERATIVA DO BRASIL: promulgada em 05 out.1988.

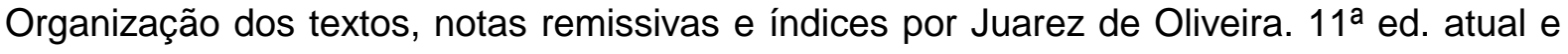
ampliada. São Paulo: Saraiva; 1995.

CRUZ, Fernanda Guimarães._Jovens em devir: invenção de novas possibilidades de vida para além da institucionalização. 2014. p. 337. Tese (Doutorado em Antropologia Social) Programa de Pós-graduação em Antropologia Social, Universidade Federal de Santa Catarina, Florianópolis, 2014.

DENCKER, A. de F. M. Métodos e técnicas de pesquisas em turismo. 4aㅡ ed. São Paulo: Futura, 2000.

DUARTE, L. F. D. Horizontes do indivíduo e da ética no crepúsculo da família. In: RIBEIRO, I. (Org.). Família e sociedade brasileira: desafios nos processos contemporâneos. Rio de Janeiro: Fundação João XXIII, 1994. p. 23-41.

FASSIN, Didier. 1998. "Politique des corps et gouvernament de villes: la production locale de la santé publique. In FASSIN, D. (Org). Les figures urbanesde la santé publique. Paris: Le Decouvert, 1998, p. 7 - 44.

FONSECA, Claudia. Caminhos da adoção. São Paulo, Editora Cortez, 1995.

FONSECA, Claudia; SCHUCH, Patrice (org.). Políticas de proteção à infância: um olhar antropológico. Vol. 1. Porto Alegre: Ed. da UFRGS, 2009. p. 93-112. 
FOUCAULT, M. A Hermenêutica do sujeito: curso dado no Collége de France (1981-1982). São Paulo: Martins Fontes, 2010.

. História da sexualidade: a vontade de saber. Rio de Janeiro: Graal, 1988.

. História da sexualidade: o uso dos prazeres. Rio de Janeiro: Graal, 1984.

O sujeito e o poder. In H. Dreyfus, \& P. Rabinow (Org.), Michel Foucault, uma trajetória filosófica: Para além do estruturalismo e da hermenêutica. Rio de Janeiro: Forense Universitária, 1995.

Segurança, território, população: Curso dado no Collège de France (1977-1978). São Paulo: Martins Fontes, 2008ª .

Nascimento da biopolítica: Curso dado no Collège de France (1978-1979). São Paulo: Martins Fontes, 2008b.

GREGORI, M. F. Viração: Experiência de Meninos nas Ruas. São Paulo: Companhia das Letras, 2000.

GULASSA, M. L.C.R. - NECA, 2010. Imaginar para encontrar a realidade: reflexões e propostas para trabalho com jovens nos abrigos / [coordenação da publicação Maria Lucia Carr Ribeiro Gulassa] . -- 1. ed. -- São Paulo : Associação Fazendo História : Associação dos Pesquisadores de Núcleos de Estudos e Pesquisas sobre a Criança e o Adolescente. (Coleção abrigos em movimento).

JOCILES, M. I., Rivas, A. M., Monco, B., \& Villaamil, F. (2010). Madres solteras por eleccion: Entre "el engano" y la solidaridad. Revista de Antropologia Iberoamericana.

LLUCH, Enric; DÍEZ, A. Miguel. O homem do saco. Rio de Janeiro: Editora FTD, 2012.

LOUW, D. J. The african concepto of ubuntu and retorative justice, 1997. Disponível em https://books.google.com.br/books?hl=pt-BR\&lr=\&id=v8Y8cZk8

g4C\&oi=fnd\&pg=PA161\&dq=Teffo,+1994a:+4+\%E2\%80\%93+Towards+a+conceptualization +of+Ubuntu\&ots=mwW5_vHFRu\&sig=uzFxy7WUlcCgIG09H0MeNdBLkLY\#v=onepage\&q= Teffo\%2C\%201994a\%3A\%204\%20\%E2\%80\%93\%20Towards\%20a\%20conceptualization\% 20of\%20Ubuntu\&f=false. Acesso em 26 de agosto de 2018. 
KOERICH, B. R. ; RIBEIRO, Fernanda Bittencourt . Imaginários da infração juvenil: uma análise de três trajetórias da socioeducação de meio aberto. Revista lluminuras, v. 18, p. 102-123, 2017.

MAGNANI, J. G. C. Na Metrópole: Textos de Antropologia Urbana, 2008.

MAIA, J. M. D., WILLIAMS, L. C. de A. (2005). Fatores de risco e fatores de proteção ao desenvolvimento infantil: Uma revisão da área. Temas em Psicologia, 13(2),91-103.

MALFITANO, Ana Paula Serrata; ADORNO, Rubens de Camargo Ferreira. Infância, juventude e vivências nas ruas: entre o imaginário da instituição e do direito. Imaginario, São Paulo, v. 12, n. 12, p. 15-33, jun. 2006 . Disponível em $<$ http://pepsic.bvsalud.org/scielo.php?script=sci_arttext\&pid=S1413666X2006000100002\&lng=pt\&nrm=iso >. Acessado em: 11 set. 2017.

MARQUESE, Rafael de Bivar. A dinâmica da escravidão no Brasil: resistência, tráfico negreiro e alforrias, séculos XVII a XIX. Novos estud. - CEBRAP, São Paulo, n. 74, p. 107123, Mar. 2006 Disponível em: $<$ http://www.scielo.br/scielo.php?script=sci_arttext\&pid=S0101$33002006000100007 \&$ Ing=en\&nrm=iso >. Accessado em: 12 set.. 2017.

MEDAETS, Chantal. 2015. "Malgré les adultes: une ethnographie des situations non scolaires d'apprentissage chez les habitants du bas-Tapajós (Amazonie brésilienne)". Tese de Doutorado em Educação. Université Paris Descartes (França).

MELO, E.R. Direito e norma no campo da sexualidade na infância e adolescência. In: UNGARETTI, M. A (Org.). Criança e adolescente: direitos, sexualidades e reprodução. São Paulo: ABMP, 2010. p. 43-60.

MICHAELIS. Dicionário online. Disponível em: https://michaelis.uol.com.br. Acesso em: ww. Xx. 2019

MOURA, Maria B.A. M. Dinâmicas institucionais revitimizadoras: necessidade de reorganização e articulação do fluxo interinstitucional de atendimento e aprimoramento da justiça. Secretaria Nacional de Promoção dos Direitos da Criança e do Adolescente, Rio de Janeiro, 2012.

Disponível

em: 
http://www.isaconsultoria.com.br/media_upload/Justi\%C3\%A7a\%20restaurativa.5c74302a1f 470.pdf\#page=108. Acessado em: 03 de março de 2017.

OLIVEIRA, A. P. G., \& MILNITSKY-SAPIRO, C. (2007). Políticas públicas para adolescentes em vulnerabilidade social: Abrigo e provisoriedade. Psicologia: Ciência e Profissão, 27(4), 622-635. do:10.1590/S1414-98932007000400005.

ONU (1989). Convenção sobre os Direitos da Criança. Genebra: ONU Disponível em: http://www.unric.org/html/portuguese/humanrights/Crianca.pdf>. Recuperado em 20 de outubro de 2011. Acessado em: 26 de março de 2017.

ONU (2000). Protocolo facultativo para a Convenção sobre os Direitos da Criança. Genebra: ONU. Disponível em: <http://www.unicef.org/brazil/pt/resources_10123.htm>. Acessado em: 15 de abril de 2018.

ONU BRASIL, Portal (2015) Disponível em: http://gaz.com.br/conteudos/geral/2015/04/13/45261segundo_a_onu_mais_de_150_milhoes_de_criancas_vivem_nas_ruas.html.php. Acessado em: 18 de agosto de 2018.

PORTAL Fazendo História (2018). Disponível em : https://www.fazendohistoria.org.br/bloggeral/2018/8/1/sistematizao-da-oficina-projeto-poltico-pedaggico-boas-prticas-nos-serviosde-acolhimento. Acesso em 10 de novembro de 2018.

PORTAL Observatório do Terceiro Setor, 2018. Disponível em: https://observatorio3setor.org.br/carrossel/47-mil-criancas-e-adolescentes-vivem-emabrigos-no-brasil/. Acesso em 18 de abril de 2019.

PORTAL Prefeitura de São Paulo, 2016. Edital de processo seletivo para instalação de SAICA. Disponível em: https://www.prefeitura.sp.gov.br/cidade/secretarias/upload/assistencia social/Editais\%20201 9/064\%202019\%20CHAMAMENTO.pdf. Acesso em 07 de maio de 2017. 
PRESTES, Andréia Baia. Ao abrigo da família - Emoções, cotidiano e relações em instituições de abrigamento de crianças e adolescentes em situação de risco social e familiar. Curitiba: CRV, 2011.

QUIJANO, A. Colonialidad y modernidad/racionalidade. Perú Indígena, Lima, v.12, n.29, p.11-20, $1992 . \quad$ Disponível em: https://enriquedussel.com/txt/Textos 200 Obras/Giro descolonizador/Colonialidad moderni dad-Anibal Quijano.pdf. Acesso 23 de abril de 2018.

RAMOS, Fábio. Educação, Escola, Família e Sociedade. http://fabiopestanaramos.blospot.com.br/2011/05/educacao-escola-familiasociedade. Acesso em 06 de maio de 2019.

REPPOLD, C. T., PACHECO, J., BARDAGI, M., \& HUTZ, C. Prevenção de problemas de comportamento e desenvolvimento de competências psicossociais em crianças e adolescentes: Uma análise das práticas educativas e dos estilos parentais. In C. S. Hutz (Org.), Situações de risco e vulnerabilidade na infância e na adolescência: Aspectos teóricos estratégias de intervenção (pp. 7-51).São Paulo, SP: Casa dos Psicólogos, 2002.

RESOLUÇÃO CONJUNTA CNAS/CONANDA nำ 1/2009, de 18 de junho de 2009 Aprova 0 documento Orientações Técnicas: Serviços de Acolhimento para Crianças e Adolescentes http://www.crianca.mppr.mp.br/modules/conteudo/conteudo.php?conteudo=1350.

RIBEIRO, Fernanda Bittencourt. Acolhimento de famílias e modos de apoio à (pluri) parentalidade. Scripta Nova (Barcelona), JCR, v. XVI, p. 4, 2012. Lealdades, silêncios e conflitos: Ser um dos "grandes" num abrigo para famílias. Civitas: Revista de Ciências Sociais (Impresso), v. 11, p. 40-55, 2011.

RIZZINI, Irene; RIZZINI, Irma. A institucionalização de crianças no Brasil: percurso histórico e desafios do presente. Rio de Janeiro: PUC-Rio, 2004.

ROSEMBERG, F. O discurso sobre Criança de Rua na Década de 80. Temas em Debate. Fundação Carlos Chagas. PUC/SP, 1993.

ROSENBERG, Marshall B. Comunicação não-violenta. Técnicas para aprimorar relacionamentos pessoais e profissionais. 3. ed. São Paulo: Ágora, 2006. 
SECRETARIA ESPECIAL DOS DIREITOS HUMANOS. Conselho Nacional dos Direitos da Criança e do Adolescente. Sistema Nacional de Atendimento Socioeducativo: SINASE. Brasília, DF: Conanda, 2006.

SETTON, Maria da Graça Jacintho. Família, escola e mídia: um campo com novas configurações. Educ. Pesqui. [online]. 2002, vol.28, n.1 [cited 2019-09-07], pp.107-116. Available from: $\quad<h t t p: / / w w w . s c i e l o . b r / s c i e l o . p h p ? s c r i p t=s c i \_a r t t e x t \& p i d=S 1517-$ $97022002000100008 \& \operatorname{lng}=e n \& \mathrm{nrm}=\mathrm{iso}>$. ISSN $1517-$ 9702. http://dx.doi.org/10.1590/S1517-97022002000100008.

SILVA, E. R. A. (2004). O direito à convivência familiar e comunitária: Os abrigos para crianças e adolescentes no Brasil. Brasília, DF: Instituto de Pesquisa Econômica Aplicada.

SIQUEIRA, A. C. Instituição de abrigo, família e redes de apoio social e afetivo em transições ecológicas na adolescência. Dissertação de Mestrado, Universidade Federal do Rio Grande do Sul, Porto Alegre. Siqueira, A. C., Betts, M. K., \& Dell'Aglio, D. D. (2006). Redes de apoio social e afetivo de adolescentes institucionalizados. Interamerican Journal Psychology, 40, 149-158. Siqueira, A. C., \& Dell'Aglio, D. D. (2006). O impacto da institucionalização na infância e na adolescência: uma revisão de literatura. Psicologia \& Sociedade, 18(2), 71-80, 2006

SIQUEIRA, Aline Cardoso; MASSIGNAN, Lucianna Tortorelli and DELL'AGLIO, Débora Dalbosco. Reinserção familiar de adolescentes: processos malsucedidos. Paidéia (Ribeirão Preto) [online]. 2011, vol.21, n.50 [cited 2016-09-13], pp.383-391. Disponível em: http://www.scielo.br/scielo.php?script=sci_arttext\&pid=S0103-

863X2011000300011\&lng=en\&nrm=iso Acessado em: ISSN 0103-863X. http://dx.doi.org/10.1590/S0103-863X2011000300011.

SOUZA, A. S. A. O sentido das drogas para adolescentes em situação de rua. 2001. 300 p. Dissertação de Mestrado em Psicologia Social, Pontifícia Universidade Católica. São Paulo, SP.

SZYMANSKI, Heloísa. Viver em família como experiência de cuidado mútuo: desafios de um mundo em mudança. In Serviço Social e Sociedade. № 71: São Paulo, Cortez, setembro de 2002. 
TORRES, A. (coord.), PEGAdO, E., HILÁRIO, A., CRUZ, R., PENHA, A., SOUSA, I., e SARMENTO, M. Estudo de Diagnóstico e Avaliação das Comissões de Proteção de Crianças e Jovens: Relatório Final, Lisboa, 2008.

VASCONCELOS, Q. A., YUNES, M. A. M., \& GARCIA, N. M. Um estudo ecológico sobre as interações da família com o abrigo. Paidéia (Ribeirão Preto), 19(43), 221-229, 2009 do:10.1590/S0103--863X2009000200010.

YANO, Karen Murakami; RIBEIRO, Moneda Oliveira. O desenvolvimento da sexualidade de crianças em situação de risco. Rev. esc. enferm. USP, São Paulo , v. 45, n. 6, p. 13151322, Disponível em: <http://www.scielo.br/scielo.php?script=sci_arttext\&pid=S008062342011000600006\&lng=en\&nrm=iso>. Acessado em: 31. Mar. 2019 http://dx.doi.org/10.1590/S0080-62342011000600006.

YUNES, M. A. M., MIRANDA, A. T., \& CUELLO, S. E. S. Um olhar ecológico para os riscos e as oportunidades de desenvolvimento de crianças e adolescentes institucionalizados. In S. H. Koller (Ed.), A ecologia do desenvolvimento humano: Pesquisa e intervenção no Brasil (pp. 197-218). São Paulo, SP: Casa do Psicólogo, 2004.

ZALUAR, A. Integração perversa: pobreza e tráfico de drogas. Rio de Janeiro: Editora FGV (Fundação Getúlio Vargas), 2004. 


\section{APÊNDICE}

\subsection{APÊNDICE A}

\section{ROTEIRO DE ENTREVISTA ETNOGRÁFICA SEMIESTRUTURADA}

Crianças e Familiares

1. Quanto tempo viveu em situação de rua?

2. Como foram as vivências nas ruas?

3. Como foi o processo de acolhimento institucional?

4. Quanto tempo ficou no serviço de acolhimento?

5. Como ocorreu o processo de reinserção familiar?

6. Como foi morar com a família?

7. Houve reinstitucionalização? Caso sim, como ocorreu?

8. Como está o cenário atual de moradia e vínculos familiares e comunitários?

9. Como está o cenário atual de vivência institucional?

10. Como foram as vivências de processos desertores com rupturas nas relações familiares? 


\subsection{APÊNDICE B}

\section{ROTEIRO DE ENTREVISTA ETNOGRÁFICA SEMIESTRUTURADA}

Equipe da instituição de acolhimento

1 A instituição trabalha voltada para estratégias de reinserção familiar?

2 Como a instituição trabalha o processo de reinserção familiar?

3 Quais as possibilidades e desafios deste processo?

4 Como ocorre o contado da criança com vínculos familiares e comunitários?

5 Como acontece a articulação de rede implicada na reinserção familiar?

6 Quais deserções foram presenciadas pela equipe institucional na história das crianças? 


\subsection{APÊNDICE C}

ROTEIRO DE ENTREVISTA ETNOGRÁFICA SEMIESTRUTURADA

\section{Profissionais da Defensoria Pública}

1. Quais são dos dados do processo da adolescente?

2. Pode disponibilizar cópia da abertura do processo e do Boletim de Ocorrência, bem como demais documentos anexados ao processo?

3. Pode informar nome e local de trabalho do defensor público designado para a adolescente?

4. Pode anexar ao processo e enviar ao defensor público responsável uma carta de defesa da adolescente, com elementos importantes para a audiência?

5. Pode informar qual é o trâmite e agenda dos protocolos jurídicos, como oitivas e audiências previstas para o caso?

6. Pode fornecer orientações sobre melhor postura para defesa da adolescente e posicionamento diante do promotor e do juiz?

7. Qual é o prognóstico para o caso em questão quanto a aplicação de medidas socioeducativas para o ato infracional ocorrido? 


\section{ANEXO}

10.1 Edital de Processo Seletivo para Conveniar a Implantação e Gestão de Serviços de Acolhimento

\section{Edital no 110/SMADS/2016}

A Secretaria Municipal de Assistência e Desenvolvimento Social do Município de São Paulo torna pública, para ciência dos interessados, a abertura de procedimento de seleção para a instalação do serviço socioassistencial denominado SERVIÇO DE ACOLHIMENTO INSTITUCIONAL PARA CRIANÇAS E ADOLESCENTES - SAICA, no distrito especificado no item 1.1 deste edital, para operacionalização descentralizada conforme Decreto $\mathrm{n}^{\circ}$ 54.073 de 04/07/2013, pela Supervisão de Assistência Social - Itaquera/SAS-IQ, devendo as Organizações/Entidades/Associações sem fins econômicos, interessadas no estabelecimento de parceria com esta Pasta, apresentar suas propostas no local e data identificados no item 2. O procedimento de conveniamento reger-se-á pelas disposições

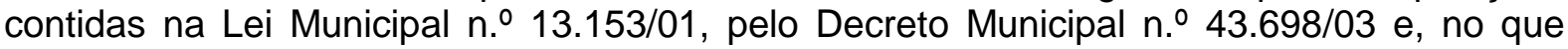
couber, pela legislação em vigor, bem como pelas condições estabelecidas neste Edital.

1 - OBJETO

1.1. O presente Edital tem como objeto tornar público o interesse da Municipalidade em oferecer o seguinte serviço socioassistencial, a saber:

1.1.1 - Distrito: Itaquera

1.1.2 - Supervisão de Assistência Social: Itaquera- SAS -IQ

1.1.3 - Área de Abrangência: Regional abrangendo todos os distritos da Subprefeitura de Itaquera

1.1.4 - Tipo de Serviço: SERVIÇO DE ACOLHIMENTO INSTITUCIONAL PARA CRIANÇAS E ADOLESCENTES - SAICA

1.1.5 - Quantidade de unidade(s) de Serviço a ser conveniada: 01 unidade

1.1.6 - Vagas: 15 vagas, excepcionalmente 17 vagas em períodos de baixa temperatura.

1.1.7 - Bem Imóvel: Locado pela Organização com repasse de SMADS, na área de abrangência do distrito de Itaquera, Subprefeitura Itaquera.

1.1.8 - Valor de repasse de recurso mensal:

$\mathrm{R} \$$ 68.993,00 para organização COM ISENÇÃO da cota patronal do INSS e até R\$ $6.000,00$ para IPTU e aluguel ou outro valor para aluguel no limite da avaliação locatícia realizada pela SMADS mais IPTU

$\mathrm{R} \$ 80.497,92$ para organização SEM ISENÇÃO da cota patronal do INSS e até $\mathrm{R} \$ 6.000,00$ para IPTU e aluguel ou outro valor para aluguel no limite da avaliação locatícia realizada pela SMADS mais IPTU

1.1.9 - Verba de Implantação: R\$15.000,00 (Quinze Mil Reais)

1.2. As ofertas e os padrões específicos exigidos pela Secretaria Municipal de Assistência e Desenvolvimento Social para este tipo de serviço estão detalhados na Portaria 46/SMADS/2010 com suas alterações, Portaria 47/SMADS/2010, Portaria 26/SMADS/2015, Portaria 27/SMADS/2015, Norma Técnica dos Serviços Socioassistenciais - Proteção Social Básica e Especial, publicada em 07/12/2012 e instituída pela Portaria no 21/SMADS/GAB/2012 e nas informações complementares descritas no Anexo $V$ deste edital, que deverão ser usadas como parâmetros pelas organizações/entidades/associações, quando da apresentação de suas propostas, conforme item 3 deste edital;

1.3. As Organizações/Entidades/Associações poderão apresentar proposta para o serviço desde que atendidas às disposições previstas neste Edital;

1.4. A proposta deverá ser apresentada dentro de um envelope endereçado à Supervisão de Assistência Social mencionada no subitem 1.1.2 deste edital. 
2 - CONSTITUIÇÃO DO COMITÊ DE AVALIAÇÃO, LOCAL, DIA E HORA PARA RECEBIMENTO E VERIFICAÇÃO DAS PROPOSTASS E CONVOCAÇÃO DA AUDIÊNCIA PÚBLICA.

2.1. O Comitê de Avaliação designado pela Supervisão de Assistência Social mencionada no subitem 1.1.2 deste edital, nos termos do art.16 do Decreto 43.698 de 02 de setembro de 2003 e das Portarias n 31/SAS/GAB/2003 e 19/SMADS/2007 de 23/08/07, será constituído da forma que segue:

TITULARES:

Camila de Fátima Munhoz - RF 779.425-8 (Presidente)

Wesley Rodrigues da Silva - RF 815.554-2

Camilla da Silva Montel - RF 787.594-1

SUPLENTES:

Rene Ribeiro Silva - RF 610.006-6

Cristiane Chaves da Silva Pimenta - RF 790.333-2

2.2. Caberá a SMADS convidar para a Audiência Pública representante do Conselho Municipal de Assistência Social - COMAS e demais conselhos de direitos afetos ao serviço tratado neste edital, devendo constar do processo que cuidará do procedimento cópia do ofício protocolado no referido conselho;

2.3. O Comitê de Avaliação designado e conforme consta no subitem 2.1 receberá envelope endereçado à Supervisão de Assistência Social mencionada no subitem 1.1.2 deste edital, contendo a Proposta da Organização/ Entidade/Associação sem fins econômicos para o serviço do item 1 - "objeto" deste edital da forma que segue:

Data: 13/09/2016

Horário: das 10:00 às 12:00 horas

Local: Av. Maria Luiza Americano, 1.877 Cidade Líder- CEP 08275-000

2.4. Somente serão consideradas as propostas entregues diretamente aos membros do Comitê de Avaliação no dia, local e horário indicado neste edital;

2.5. Caberá a cada Comitê de Avaliação verificar, no momento da entrega e na presença da interessada, se a proposta está instruída com os elementos exigidos neste edital, devendo rubricar todos os elementos entregues nesta ocasião;

2.6. Caberá ao Comitê de Avaliação verificar no site www.prefeitura.sp.gov.br, na página de Finanças, no link para o CADIN se a organização proponente consta do Cadastro Informativo Municipal - CADIN, pois em caso positivo significa que a organização possui pendência com a Administração Pública Municipal e seus órgãos ficam impedidos de celebrar convênios com a mesma, conforme Decreto o 47.096 de 21/03/2006. O Comitê deverá orientar a proponente a proceder a regularização da pendência até a data de assinatura do convênio caso seja considerada apta.

2.7. A Audiência Pública designada pela Supervisão de Assistência Social mencionada no subitem 1.1.2 deste edital, nos termos do artigo 14 do Decreto 43.698 de 02 de setembro de 2003 e da Portaria 31/SAS/2003 e 19/SMADS/2007 de 23/08/07, que será realizada da forma que segue: DATA: 20/09/2016 HORÁRIO: 14:00 horas LOCAL: Auditório da SAS- IQ situado na Rua Fontoura Xavier, $n^{\circ} 695$ - Vila Carmosina- Itaquera - CEP 08295-300

3 - FORMA DE APRESENTAÇÃO DAS PROPOSTAS

3.1. A Proposta da Organização/Entidade/Associação Interessada para o tipo de serviço descrito no item 1 - "objeto" deste edital, deverá ser apresentado de forma escrita, dentro de um envelope, devendo ainda ser instruída com os seguintes elementos:

3.1.1. Declaração de matrícula ou credenciamento em SMADS, bem como declaração, assinada pelo representante legal da organização/entidade/associação, de estar apta a apresentar os documentos exigidos em conformidade com o disposto no artigo 11 da Portaria n 31/2003/SAS/GABINETE alterada pela Portaria $n^{\circ}$ 19/SMADS/GAB/2007, para fins de celebração de convênio com o Município;

3.1.2. Inscrição da organização/entidade/associação no Conselho Municipal de Assistência Social - COMAS, em conformidade com a Resolução 1080 do COMAS-SP de 31 de março de 2016 e protocolo de manutenção; 
3.1.3. Inscrição da organização/entidade/associação no Conselho Municipal dos Direitos da Criança e do Adolescente - CMDCA, quando o objeto tratar especificamente de usuários crianças e adolescentes;

3.1.4. Detalhamento do currículo de experiências sociais da organização/entidade/associação sem fins econômicos

3.1.4.1. Apresentar suas experiências na área social e declarações de reconhecimento de suas práticas emitidas por instituições governamentais e não governamentais, de reconhecida expressão, nacional ou internacional, caso existam;

3.1.4.2. Apresentar parcerias com outras instituições, universidades e empresariado para gestão dos serviços já desenvolvidos, bem como aquelas que pretende estabelecer, demonstrando sua capacidade de realizar e manter parcerias para a gestão do serviço ora proposto.

3.1.5. Detalhamento de sua Proposta de Desenvolvimento de Serviço ou Projeto descrevendo em relação à unidade escolhida:

3.1.5.1. As instalações a serem utilizadas;

3.1.5.2. A abrangência territorial da ação a ser desenvolvida em congruência com o estabelecido pela SAS;

3.1.5.3. A vinculação da ação com as orientações do Plano Municipal de Assistência Social e diretriz nacional - LOAS, PNAS, SUAS / Proteção Social Básica e Especial / CRAS / CREAS / CREAS POP / Tipificação Nacional de Serviços Socioassistenciais, Protocolo de Gestão Integrada de Serviços, Benefícios de Transferência de Renda;

3.1.5.4. A forma que utilizará para acesso dos usuários e de controle da demanda pelas ofertas do serviço;

3.1.5.5. A metodologia a ser desenvolvida para as ofertas socioeducativas e sociais, evidenciando para a acolhida, de modo a demonstrar as estratégias de atuação para alcance das metas de atendimento;

3.1.5.6. A forma de monitoramento e avaliação dos resultados e metas estabelecidas para o desenvolvimento do serviço;

3.1.5.7. Demonstrar conhecimento do território de implantação do serviço e do trabalho social com famílias em situação de vulnerabilidade;

3.1.5.8. Demonstrar conhecimento e capacidade de articulação com serviços da rede socioassistencial local e políticas públicas setoriais, no âmbito territorial direcionado as crianças, adolescentes e famílias.

3.1.6. Detalhamento dos Recursos Humanos na gestão do serviço, em conformidade com o estabelecidos na Portaria 46/2010/SMADS e suas alterações para cada tipologia:

3.1.6.1. Especificar no quadro de recursos humanos a formação de cada profissional, bem como, a carga horária, habilidades, atribuições e competências;

3.1.6.2. Especificar a distribuição dos profissionais para a operacionalização e gestão do serviço para a garantia dos resultados e metas estipuladas;

3.1.6.3. Especificar a proposta de capacitação continuada que será realizada para o quadro de recursos humanos;

3.1.6.4. Especificar que o processo de seleção e capacitação continuada dos profissionais do serviço, será em conjunto com SAS / CRAS ou CREAS e SMADS / Proteção Social Básica ou Especial e Espaço do Aprender Social - ESPASO.

3.1.7. Detalhamento da aplicação dos Recursos Financeiros na gestão do serviço, conforme modelo do Anexo VI desta Portaria:

3.1.7.1. Especificar a distribuição dos recursos financeiros para a operacionalização e gestão do serviço por elemento de despesa para cada tipologia;

3.1.7.2. Especificar os custos mensais e anuais estimados, respeitando para a composição do custo mensal a contemplação dos elementos de despesas contidos no Anexo V deste edital para cada tipologia; 
3.1.7.3. Especificar a eventual contrapartida da organização/associação/entidade sem fins econômicos na gestão do serviço;

3.1.7.4. Informar se há necessidade de verba de implantação, especificando o valor e detalhando a sua utilização, observado o valor limite máximo mencionado no subitem 1.1.10, a qual deve destinar-se ao pagamento de despesas iniciais para a implantação do serviço;

3.1.7.4.1 Fica vedada a solicitação/concessão de verba de implantação caso a organização que vença a audiência seja a mesma que vinha executando o serviço.

3.1.7.4.2. Em casos excepcionais e devidamente justificados, a critério de SMADS, quando houver situação que importe novação, a organização/entidade/associação que vinha executando o serviço e vença a audiência, poderá receber verba.

4 - DATA E FORMA DE DISCUSSÃO DAS PROPOSTAS NAS AUDIÊNCIAS PÚBLICAS

4.1. As propostas recebidas serão apresentadas em audiência pública, especialmente convocada para este fim, para manifestação de usuários, moradores, representantes de Conselhos, dentre outros, e para eventuais complementações e esclarecimentos das organizações/entidades/ associações proponentes.

4.2. As regras para realização das audiências públicas e participação das organizações e associações interessadas estão disciplinadas na Portaria n. ${ }^{\circ}$ 31/2003/SAS/GABINETE alterada pela Portaria . $^{\circ}$ 19/SMADS/GAB/2007.

5 - QUANTO ÀS AUDIÊNCIAS PÚBLICAS

5.1. Na audiência pública, as organizações/entidades/associações deverão ser representadas por seu representante legal ou por pessoa devidamente credenciada pelo responsável legal da instituição.

5.2. O credenciamento far-se-á por um dos seguintes meios:

5.2.1. Instrumento público de procuração pelo qual a organização tenha outorgado plenos poderes ao credenciado, podendo este representá-la na audiência pública e oferecer esclarecimentos e informações que forem necessários;

5.2.2. Instrumento particular de procuração/credenciamento (conforme Anexo I deste edital) pelo qual a organização tenha outorgado poderes ao credenciado para representá-la na audiência e oferecer esclarecimento e informações que forem necessárias.

5.3. A Organização/Entidade/Associação que tenha apresentado proposta, mas que não esteja presente no momento da audiência em conformidade com o descrito no item 5.1, ficará impossibilitada de oferecer informações e/ou complementações à proposta caso seja necessário, resultando na inaptabilidade da proponente.

5.4. Julgando necessário, o comitê de avaliação, no decorrer da audiência pública, poderá conceder o prazo de até 2 (dois) dias úteis para que as organizações proponentes apresentem, por escrito, os esclarecimentos e complementações indicados na audiência pública, que deverão ser protocolados na Supervisão de Assistência Social mencionada no subitem 1.1.2, junto a um dos membros do Comitê de Avaliação.

6 - CRITÉRIOS DE ANÁLISE DAS PROPOSTAS

6.1. O Comitê de Avaliação apresentará parecer técnico analisando as propostas apresentadas, as condições legais das proponentes e as manifestações produzidas em audiência pública, manifestando e justificando a escolha daquela mais apta para executar 0 serviço, de acordo com os seguintes critérios:

6.1.1. Congruência da proposta com o Plano Municipal de Assistência Social do Município de São Paulo - PLAS-sp, de forma a verificar as possibilidades que a proposta apresentada oferece para alcance das metas nele indicadas;

6.1.2. Qualidade das experiências sociais da organização/entidade/associação proponente e a compatibilidade delas com o tipo de serviço a ser executado, a luz do currículo de experiências sociais e das declarações de reconhecimento de suas práticas emitidas por instituições governamentais, de reconhecida expressão, nacional ou internacional; 
6.1.3. Capacidade em atender as metas estabelecidas;

6.1.4. Compatibilidade entre a proposta apresentada, as ofertas e os padrões específicos que compõem o tipo de serviço indicado no item 1 - objeto deste edital, constantes nas Portarias 46/2010/SMADS e 47/2010/SMADS publicadas em DOC 15/02/2011 com suas respectivas alterações, Norma Técnica dos Serviços Socioassistenciais - Proteção Social Básica e Especial publicada em 07/12/2012 e instituída pela Portaria $\mathrm{n}^{\circ}$ 21/SMADS/GAB/2012 e nas informações complementares descritas no Anexo $V$ deste edital;

6.1.5. Compatibilidade entre os valores apresentados no "Demonstrativo de Custeio do Serviço Conveniado" da proposta apresentada com as normas estabelecidas na Portaria 27/SMADS/2015 e suas alterações e informações contidas no Anexo V deste edital;

6.1.6. Capacidade de potencializar e distribuir recursos humanos para a gestão dos serviços e a garantia de viabilizar resultado;

6.1.7. Especificação e qualificação dos recursos humanos que disponibilizarão para o serviço, segundo parâmetros da SMADS;

6.1.8. Disposição para garantir o caráter público da parceria com a Prefeitura do Município de São Paulo, na divulgação do serviço a ser prestado e na atenção ao usuário;

6.1.9. Capacidade e disposição de manter relação de referência/contra-referência entre o Centro de Referência de Assistência Social - CRAS / Centro de Referência Especializado de Assistência Social - CREAS e as vagas dos serviços conveniados, de forma a operar as suas ações integradas em rede e a atender a demanda dos usuários;

6.1.10. Capacidade da organização/entidade/associação sem fins econômicos de garantir contrapartida na gestão do serviço a ser conveniado;

6.1.11. Capacidade de realizar parcerias com a iniciativa privada, terceiro setor, universidades entre outros na gestão do serviço;

6.1.12. Complementação dos elementos da proposta e esclarecimentos apresentados pela organização/entidade/associação sem fins econômicos proponente, em audiência pública.

6.2. O parecer do Comitê de Avaliação será publicado no Diário Oficial da Cidade, no prazo de até 7 (sete) dias, após a realização da audiência pública. Elaborado pela SMADS/CPC em abril/2016 6

7 - POSSIBILIDADE DA MANIFESTAÇÃO DAS ORGANIZAÇÕES/ ENTIDADES/ASSOCIAÇÕES ACERCA DO PARECER TÉCNICO DO COMITÊ DE AVALIAÇÃO

7.1. A organização/entidade/associação proponente poderá apresentar manifestação, no prazo de 5 (cinco) dias contínuos, a contar da data da publicação do parecer técnico do Comitê de Avaliação no Diário Oficial da Cidade de São Paulo.

7.2. O prazo para manifestação é contado excluindo-se o dia da publicação, e incluindo-se o dia do vencimento.

7.2.1. Considera-se prorrogado o prazo estipulado até o primeiro dia útil, se o vencimento ocorrer no sábado, domingo, feriado, ponto facultativo municipal ou se o expediente administrativo for encerrado antes do horário normal;

7.2.2. Só se iniciam e vencem prazos em dia de expediente normal.

7.3. A manifestação da organização/entidade/associação proponente será analisada pela Supervisão de Assistência Social mencionada no subitem 1.1.2 quando da efetiva escolha e elaboração de parecer indicando a organização ou associação mais apta a celebrar a parceria mediante convênio.

8 - ELABORAÇÃO DE PARECER PELO SUPERVISOR DE ASSISTÊNCIA SOCIAL INDICANDO A ORGANIZAÇÃO/ENTIDADE/ASSOCIAÇÃO APTA A CELEBRAR O CONVÊNIO E DESPACHO HOMOLOGATÓRIO

8.1. O Supervisor da Supervisão de Assistência Social mencionado no subitem 1.1.2 emitirá parecer indicando e justificando a organização/entidade/associação mais apta a celebrar a parceria mediante convênio, o qual será submetido ao Titular da Secretaria Municipal de Assistência e Desenvolvimento Social, para homologação.

8.2. O despacho homologatório autorizando a celebração do convênio será publicado no Diário Oficial da Cidade de São Paulo. 


\section{9 - DOCUMENTOS EXIGIDOS PARA A CELEBRAÇÃO DO CONVÊNIO}

9.1. São exigidos para a celebração do convênio os seguintes documentos, que devem ser entregues na Supervisão de Assistência Social mencionada no subitem 1.1.2.

a) Cópia da ata de reunião de eleição e posse da diretoria em exercício, registrada no Cartório de Registro Civil de Pessoa Jurídica; e quando não constar na ata o período do mandato da diretoria deverá ser apresentado também o Estatuto da organização;

b) Cópia da Certidão Negativa de Débitos Relativos aos Tributos Federais e à Dívida Ativa da União abrangendo inclusive as contribuições sociais previstas nas alíneas "a" a "d" do parágrafo único do artigo 11 da Lei $n=8.212$, de 24 de julho de 1991 com prazo de validade em vigência;

c) Cópia da certidão de regularidade referente ao Fundo de Garantia por Tempo de Serviço - FGTS, com prazo de validade em vigência;

d) Conta corrente específica da organização ou associação para recebimento dos reembolsos advindos do convênio, especificamente no Banco do Brasil;

e) Declaração da organização/entidade/associação escolhida de que não possui menores de 18 (dezoito) anos realizando trabalho noturno, perigoso ou insalubre, nem menores de 16 (dezesseis) anos realizando qualquer trabalho, salvo na condição de aprendiz, a partir de 14 (quatorze) anos, cumprindo o disposto no inciso XXXIII do artigo $7^{\circ}$ da Constituição Federal, sob as penas da lei;

Elaborado pela SMADS/CPC em abril/2016

f) Certidão de Isenção do Imposto Sobre Serviço - ISS ou protocolo do pedido de seu reconhecimento. Caso não apresentados, haverá retenção de 5\% do ISS;

g) Cópia do Certificado de Entidade Beneficente de Assistência Social, com validade em vigência, no caso da organização ter o reconhecimento pelo Ministério do Desenvolvimento Social e Combate à Fome - MDS;

h) Cópia da Certidão Negativa de Débitos Trabalhistas - CNDT;

i) Declaração assinada por cada membro da diretoria executiva da entidade, atestando que não incidem nas vedações constantes do artigo $1^{\circ}$ - do Decreto nํ 53.177/2012 (Anexo III deste edital);

j) Certificado de Regularidade Cadastral - CENTS e/ou protocolo de recadastramento anual;

k) Termo de Responsabilidade, quando tratar-se de imóvel cedido pela organização ou locado com repasse de recursos por SMADS(Anexo IV deste edital).

9.2. A celebração do convênio está sujeita à assinatura de documento Termo de Responsabilidade, conforme disposto no artigo 12 da Portaria no 31/2003/SAS/GABINETE, alterada pela Portaria 19/SMADS/GAB/2007, quando o imóvel for cedido ou disponibilizado pela própria organização/ entidade/ associação escolhida, ou ainda locado pela mesma.

9.3. No caso de imóvel cedido pela organização ou locado pela mesma com repasse de recursos por SMADS, além da documentação elencada no item 9.1, também deve ser complementada com a apresentação de:

$\square$ cópia do IPTU do exercício;

$\square$ cópia da Planta ou croqui do imóvel;

$\square$ declaração do proprietário informando o valor pretendido para a locação e anuência para a finalidade de uso do imóvel, quando tratar-se de locação do imóvel. 
10 - PRAZO DE VIGÊNCIA DO CONVÊNIO

10.1. O convênio a ser firmado com a organização/entidade/associação escolhida terá vigência de 24 (vinte e quatro) meses, podendo ser prorrogado por até 60 (sessenta) meses, independentemente da fonte dos recursos;

11 - REPASSE MENSAL

11.1. A Secretaria Municipal de Assistência e Desenvolvimento Social repassará mensalmente recursos financeiros à organização/entidade/associação conveniada de acordo com o custo estabelecido no subitem 1.1.9 deste edital e em conformidade com o Demonstrativo de Custeio do Serviço Conveniado aprovado;

11.2. A Secretaria Municipal de Assistência e Desenvolvimento Social repassará mensalmente a organização/entidade/associação conveniada o valor estimado a partir do valor financiado pelo órgão estadual/federal e a contrapartida municipal;

11.3. Quando o pagamento mensal estiver, integral ou parcialmente, vinculado a recursos do Fundo Municipal de Assistência Social - FMAS ou do Fundo Municipal dos Direitos da Criança e do Adolescente - FUMCAD, a liberação da parcela vinculada, por SMADS à conveniada, fica condicionada ao depósito correspondente no respectivo Fundo;

11.4. O valor do repasse mensal poderá ser alterado, por meio de ato específico desta Pasta; Elaborado pela SMADS/CPC em abril/2016

11.5. Caso venha ocorrer alteração no valor do repasse conforme item anterior durante o processo de conveniamento proposto por este edital, o mesmo será reajustado em conformidade com o novo valor previsto;

11.5. O reembolso do convênio será liberado mediante a apresentação dos documentos conforme definidos na Portaria 46/SMADS/2010 e suas alterações;

11.6. A utilização dos recursos repassados deverá ocorrer em conformidade com as normas estabelecidas na Portaria 46/2010/SMADS, Portaria 47/2010/SMADS e suas alterações, Portaria 26/SMADS/2015 e Portaria 27/SMADS/2015 e suas alterações.

12 - DATA DE ASSINATURA DO TERMO DE CONVÊNIO

12.1. O termo de convênio será previamente submetido à homologação do Titular da Secretaria Municipal de Assistência e Desenvolvimento Social, antes de sua assinatura.

12.2. O termo de convênio será assinado pelas partes após a publicação do despacho homologatório do Titular da Secretaria Municipal de Assistência e Desenvolvimento Social, no Diário Oficial da Cidade.

13 - LEGISLAÇÕES, PORTARIAS E DECRETOS PERTINENTES AO EDITAL

Lei no 8.742 de 07/11/1993 - Lei Orgânica da Assistência Social - LOAS.

Lei Municipal $\mathrm{n}^{\circ} 15.089$ publicada no DOC de 29 de dezembro de 2009, parágrafo $2^{\circ}$ do artigo 14 e Súmula Vinculante ํo 13 do Supremo Tribunal Federal, que trata da vedação da contratação de cônjuge, companheiro ou parente em linha reta, colateral ou por afinidade, até o terceiro grau para execução dos serviços públicos, a qual se aplica às entidades conveniadas com a PMSP.

Decreto o 53.177 de 04/06/2012 que define critérios e procedimentos a serem observados uniformemente pelos órgãos da Administração Pública em virtude da vedação de admissão e nomeação para cargo, emprego ou função pública de pessoas que incidam nas hipóteses de inelegibilidade previstas na legislação federal, bem como da necessidade de comprovação, pelas entidades sem fins lucrativos que mantiverem contratos ou receberem verbas do município de que seus diretores não incidem nas hipóteses de inelegibilidades conforme estabelecido na Emenda no 35 à Lei Orgânica do Município de São Paulo.

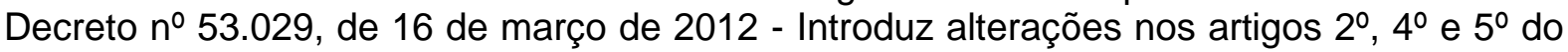
Decreto no 50.365, de 30 de dezembro de 2008, bem como cria os equipamentos sociais que especifica e estabelece as atribuições das unidades da Coordenadoria Geral de Assistência Social - COGEAS, da Secretaria Municipal de Assistência e Desenvolvimento Social.

Decreto no 54.073 , de 4 de julho de 2013 - Dispõe sobre a supressão e a vinculação de unidades da Secretaria Municipal de Assistência e Desenvolvimento Social; altera a denominação e a lotação dos cargos de provimento em comissão que especifica. 
Portaria no 31/2003/SAS/GABINETE - Detalha os procedimentos estabelecidos no Decreto Municipal $n$. 43.698/03, as regras para a realização das audiências públicas e participação das organizações/entidades/associações interessadas, e para a formalização de convênios, publicada no Diário Oficial do Município, em 06 de setembro de 2003.

Portaria 19/SMADS/2007 - Altera o 11.1 do artigo $2^{\circ}$ da Portaria 31/2003/SAS/Gabinete.

Portaria 07/SMADS/2010 - Procedimentos para instalação de serviço da rede socioassistencial SMADS/COGEAS - Fluxo detalhado de procedimentos e seus anexos: I. "Modelo de memorando para autuação de processo", II. "Instrumental para subsidiar a análise de instalação de serviço a ser conveniado com a SMADS mediante publicação de edital", III. "Orientação de Cadastro para consulta de Editais publicados no Diário Oficial da Cidade", IV. "Fluxograma" e V. "Modelo de Extrato".

Portaria 46/SMADS/2010 - Dispõe sobre a tipificação da rede socioassistencial do município de São Paulo e a regulação de parceria operada por meio de convênios. Elaborado pela SMADS/CPC em abril/2016 9

Portaria 47/SMADS/2010 - Dispõe sobre referência de custos dos serviços da rede socioassistencial operada por meio de convênios.

Portaria 12/SMADS/2014 publicada em DOC de 15 de abril de 2014 - Disciplina sobre locações de imóveis no Município de São Paulo necessários para prestação dos serviços socioassistenciais.

Portaria 26/SMADS/2015 publicada em DOC de 22 de setembro de 2015 - Dispõe sobre a majoração dos valores que servem de referência para a composição do valor do repasse mensal nos termos de convênio formalizados com organizações sociais.

Portaria 27/SMADS/2015 publicada em DOC de 01 de outubro de 2015 e suas alterações Dispõe sobre a normatização de procedimentos exigidos pela Portaria 26/SMADS/2015 de 22/09/2015.

Portaria 30/SMADS/2015 publicada em DOC de 30 de outubro de 2015 - Dispõe sobre a regulamentação dos procedimentos relativos à anualidade e à flexibilidade dos recursos repassados pela SMADS para operacionalização dos convênios firmados com as organizações da sociedade civil.

Portaria 36/SMADS/2015 publicada em DOC de 30 de outubro de 2015 - Retificam os Anexos I e III da Portaria 27/SMADS/2015.

Portaria 45/SMADS/2015 publicada em DOC de 18 de dezembro de 2015 - Regulamenta em âmbito municipal a oferta de alimentação nos serviços conveniados à SMADS.

Portaria 50/SMADS/2015 publicada em DOC de 19 de dezembro de 2015 - Altera a Portaria 30/SMADS/2015 que prorroga o prazo de que trata a Portaria 27/SMADS/2015 e das outras providências.

Portaria 04/SMADS/2016 publicada em DOC de 23 de fevereiro de 2016 - Retifica as tabelas de frequências semanal constantes do Anexo Único da Portaria 45/SMADS/2015.

Portaria 06/SMADS/2016 publicada em DOC de 30 de março de 2016 - Regulamenta a utilização da verba de implantação de que trata o artigo 24 , § $1^{\circ}$ do Decreto $n^{\circ}$ 43.698/03.

Portaria 10/SMADS/2016 publicada em DOC de 06 de abril de 2016 - Dispõe sobre a alteração na forma de pagamento dos recursos para os convênios e, por conseguinte na forma de prestação de contas mensais.

Portaria 11/SMADS/2016 publicada em DOC de 13 de abril de 2016 - Altera a redação da Portaria $n^{\circ}$ 10, de 5 de abril de 2016.

Ordem Interna 1/2012 - PGM - Institui a apresentação da Certidão Negativa de Débitos Trabalhistas em todas as licitações cujo objeto seja prestação de serviços ou execução de obra pública, independente da modalidade de licitação, inclusive no pregão

14 - DESCRIÇÃO DO SERVIÇO

De acordo com o Anexo $\mathrm{V}$ deste edital.

15 - ATRIBUIÇÕES

15.1 - Da Secretaria Municipal de Assistência e Desenvolvimento Social - SMADS

$\square$ Realizar processo de conveniamento, segundo diretrizes da Política de assistência social da cidade de São Paulo; 
$\square$ Criar indicadores de qualidade dos resultados, democratização da gestão e aprimoramento metodológico;

$\square$ Acompanhar ou participar do processo continuado de sensibilização e capacitação da rede de serviços de proteção social, organizações de promoção e defesa de direitos e sociedade civil em geral;

$\square$ Fornecer placa de identificação oficial a ser afixada nos serviços que não possuam impedimento legal.

15.2 - Da Supervisão de Assistência Social - SAS Elaborado pela SMADS/CPC em abril/2016 10

$\square$ Participar da seleção dos profissionais que atuarão no objeto deste edital;

$\square$ Participar de capacitações continuadas, tanto as oferecidas pela SMADS, como as viabilizadas pela rede local;

$\square$ Monitorar, avaliar a prestação dos serviços do serviço objeto deste edital;

Realizar a supervisão da prestação de contas e do serviço conveniado.

Elaborar Plano de Supervisão Técnica para acompanhamento, monitoramento e avaliação do serviço.

$\square$ Fortalecer a integração com a rede de serviços de Proteção Social Básica e Especial;

$\square$ Acompanhar e monitorar a evolução das demandas encaminhadas;

\section{3 - Das Organizações/ Entidades/ Associações Conveniadas}

$\square$ Realizar diagnóstico, mapeando os serviços conveniados ou não, localizando a rede de serviços a partir dos territórios de maior incidência de vulnerabilidade e riscos, de forma a propiciar a universalidade de cobertura entre indivíduos e famílias;

$\square$ Elaborar Plano de Ação seguindo as diretrizes do PLASsp;

$\square$ Realizar capacitação continuada aos profissionais do serviço

$\square$ Participar da capacitação continuada tanto as oferecidas pela SMADS, como as viabilizadas pela rede local;

$\square$ Garantir a manutenção predial e das instalações, compreendendo a execução de reparos, com vistas à preservação do imóvel, mediante avaliação e prévia aprovação da divisão de manutenção da SMADS;

$\square$ Manter, afixada no imóvel, placa de identificação do serviço objeto deste edital conforme as normas da PMSP/SMADS quando não tiver impedimento legal para publicização do serviço objeto deste edital;

$\square$ Possuir tecnologia para operar o banco de dados informatizado das famílias alvo do Programa, com acesso à Internet, pelo menos um computador com a seguinte configuração mínima: $1 \mathrm{~GB}$ de memória, processador $3.0 \mathrm{GHZ}$, superior ou equivalente, com Internet Explorer 6.0 ou superior, e Windows XP ou versão mais atualizada do Windows e impressora;

$\square$ Possibilitar que a SAS acompanhe a seleção dos profissionais do serviço, de acordo com as atribuições exigidas para cada função apresentadas na Portaria nº 46/2010/SMADS e suas alterações;

$\square$ Realizar as ações previstas no plano de trabalho, respeitando as diretrizes e eixos dos serviços;

$\square$ Manter nas ruas os orientadores socioeducativos, nos dias e horários estabelecidos na proposta de trabalho nos serviços cuja especificidade requer;

$\square$ Alimentar os sistemas de controle de dados dos serviços informatizados ou manuais, adotados pela SMADS, bem como os decorrentes das normas expedidas pela União e pelo Governo do Estado de São Paulo, ressaltando o Sistema de Atendimento, denominado SISATENDIMENTO para os serviços cujas especificidades requererem;

$\square$ Participar da sistematização, monitoramento das atividades desenvolvidas e do processo de avaliação;

$\square$ Disponibilizar o conhecimento gerado entre as demais organizações conveniadas para o serviço, bem como entre as Supervisões de Assistência Social (SAS) e SMADS por meio de encontros e seminários, relatórios e boletins informativos; 
$\square$ Cadastrar, quando necessário, as famílias no BDC ou outro instrumental definido pela SMADS, conforme especificações estabelecidas pela Portaria no 004/SMADS/SMSP/SMG de 19/09/2005;

Elaborado pela SMADS/CPC em abril/2016 11

$\square$ Publicizar a parceria com material fornecido pela SMADS e pela Organização e garantir a presença dos logos da PMSP e da SMADS nos materiais elaborados pela organização, tais como, folders, banners, convites, outros meios impressos e demais mídias.

$\square$ Locar e administrar veículos com capacidade de transporte de 9 (nove) pessoas e seus pertences, com até 5 (cinco) anos de fabricação, incluindo custo de motorista, combustível, seguros e manutenção, nos serviços especificados na Portaria 46/2010/SMADS com suas alterações.

\section{ANEXO I}

MODELO REFERENCIAL DE CREDENCIAMENTO

Pelo presente instrumento, a organização com sede na assinado, credencia o Sr.(Sra.) expedida pela SSP/ por seu representante legal infraidentidade $n^{\circ}$ portador da cédula de para representá-la na Audiência Pública referente ao Edital no outorgando-Ihe plenos poderes oferecer informações e complementações que se fizerem necessárias.

São Paulo, de de 2016.

Nome completo, função e assinatura

OBSERVAÇÕES

1. O credenciamento deverá estar acompanhado da ata de eleição da diretoria em vigência para comprovar que o seu subscritor tem poderes para outorgar o credenciamento.

2. Quando o credenciamento for conferido por procurador da entidade/organização, deverá ser ainda apresentada cópia autenticada do documento procuração, do qual deverá constar expressamente a possibilidade de substabelecimento.

ANEXO II

MINUTA DO TERMO DE CONVÊNIO

INSTRUMENTO DE GERENCIAMENTO DO CONVÊNIO

TIPO DE SERVIÇO: SERVIÇO DE ACOLHIMENTO INSTITUCIONAL PARA CRIANÇAS E ADOLESCENTES - SAICA.

CAPACIDADE: 15 VAGAS acrescidas de até 02 vagas, excepcionalmente para atender período de baixas temperaturas.

ORGANIZAÇÃO MANTENEDORA:

NOME DO SERVIÇO (nome fantasia):

TIPO DE IMÓVEL: LOCADO PELA ORGANIZAÇÃO COM REPASSE DE RECURSOS DE SMADS, NA ÁREA DE ABRANGÊNCIA DO DISTRITO DE ITAQUERA, SUBPREFEITURA ITAQUERA.

ENDEREÇO DO SERVIÇO: CEP:

DISTRITO: TODOS OS ABRANGIDOS PELA SUBPREFEITURA DE ITAQUERA.

SUPERVISÃO E ACOMPANHAMENTO DA SAS ITAQUERA.

REPASSE MENSAL $R \$ 68.993,00$ para Organização com isenção da cota patronal do INSS, e $R \$ 80.497,92$ para Organização sem isenção da cota patronal do INSS.

VALOR DESTINADO PARA ALUGUEL E IPTU: R $\$ 6.000,00$ ou outro valor para aluguel no limite da avaliação locatícia realizada por SMADS mais IPTU. Elaborado pela SMADS/CPC em abril/2016 12

VERBA DE IMPLANTAÇÃO: R\$15.000,00.

DOTAÇAO ORÇAMENTÁRIA: 93.10.08.243.3013.6221.3.3.50.39.00.0X - PROTEÇÃO ESPECIAL A CRIANÇAS, ADOLESCENTES E JOVENS EM RISCO SOCIAL.

FONTE MUNICIPAL: R $\$$

FONTE ESTADUAL: R $\$$ 
FONTE FEDERAL: R\$

VIGÊNCIA DO CONVÊNIO: DE 01/01/2017 A 31/12/2019.

A Prefeitura da Cidade de São Paulo, por meio da Secretaria Municipal de Assistência e Desenvolvimento Social (SMADS), com sede na cidade de São Paulo, Rua Líbero Badaró, 569 - Centro, inscrita no CNPJ sob o $\mathrm{n} \square$ 60.269.453/0001-40, doravante designada simplesmente SMADS, neste ato, representada pelo (a) $\mathrm{Sr}$ (a) SOELY APARECIDA SAMORA, Supervisor (a) de Assistência Social da SAS ITAQUERA, e a organização sem fins econômicos inscrita no CNPJ sob o $\mathrm{n} \square$ titular da certificação em SMADS sob o registro $\mathrm{n} \square$

inscrita no Conselho Municipal de Assistência Social sob-registro n.․ na

distrito: com sede neste ato representada pelo (a) seu (sua) presidente,

Sr.(a) portador(a) da Cédula de Identidade RG $\mathrm{n} \square$ e do Registro no CPF-MF $\mathrm{n} \square$ doravante designada simplesmente CONVENIADA, resolvem conjugar esforços e recursos mediante a celebração do presente CONVÊNIO, cujas cláusulas seguem abaixo:

I - DO OBJETIVO

CLÁUSULA PRIMEIRA - Constitui objetivo da celebração do presente convênio a conjugação de esforços e recursos, para assegurar direitos socioassistenciais para a população que deles necessitar, tendo em vista o contínuo desenvolvimento e aprimoramento das atenções oferecidas nos serviços que compõem, em rede, o Sistema Único de Assistência Social de âmbito nacional - SUAS e a política de assistência social na cidade de São Paulo, no âmbito da rede de segurança social, mantendo um sistema de vigilância, monitoramento e avaliação, que assegure padrão de qualidade no atendimento e garantia do caráter público na ação, bem como informação aos usuários de seus direitos, permitindo a troca de experiências para uma gestão descentralizada e participativa com o compromisso de buscar alternativas para reversão do processo de reprodução da desigualdade social na cidade de São Paulo.

II - DO OBJETO

CLÁUSULA SEGUNDA - O presente convênio destina-se à prestação do serviço denominado de SERVIÇO DE ACOLHIMENTO INSTITUCIONAL PARA CRIANÇAS E ADOLESCENTES - SAICA, de acordo com os padrões das ofertas que o compõem, estabelecidos no Edital de Chamamento $\mathrm{n}^{\circ}{ }_{1}$ _, publicado no DOC em e nas demais normas técnicas oriundas de SMADS, e em conformidade com a proposta de trabalho escolhida acrescida dos elementos constantes do parecer do Supervisor de Assistência Social da SAS, com área de abrangência no(s) distrito(s) TODOS OS ABRANGIDOS PELA SUBPREFEITURA DE ITAQUERA.

Parágrafo Primeiro: Para prestar o objeto indicado no caput desta cláusula, são oferecidas 15 VAGAS acrescidas de até 02 vagas, excepcionalmente para atender período de baixas temperaturas.

Parágrafo Segundo: O objeto do presente convênio será prestado de acordo com as especificações constantes na Tipificação da Rede Socioassistencial do Município de São Elaborado pela SMADS/CPC em abril/2016 13

Paulo e a regulação de parceria operada por meio de convênio, conforme Portarias 46/SMADS/2010 e suas alterações; Portaria 47/SMADS/2010; Portaria 26/SMADS/2015; Portaria 27/SMADS/2015, Portarias 10/SMADS/2016 e 11/SMADS/2016; Portaria 06/SMADS/2016 quando for o caso e Portaria 21/SMADS/GAB/2012 e descrita no Anexo V do edital.

(encartar o Anexo $\mathrm{V}$ do edital na íntegra)

III - DAS OBRIGAÇÕES DE SMADS

CLÁUSULA TERCEIRA - São obrigações da SMADS, diretamente ou por meio das Supervisões de Assistência Social - SAS em consonância com o art. 20 do Decreto Municipal n. 0 43.698, de 02 de setembro de 2003:

1. Supervisionar a execução do serviço realizado em parceria, em primeira instância de forma descentralizada por intermédio das Supervisões de Assistência Social - SAS e, em 
segunda instância, pela Secretaria Municipal de Assistência e Desenvolvimento Social, órgão executor da política municipal de assistência social, à luz da proposta de trabalho apresentada pela CONVENIADA e acrescida dos elementos constantes do parecer do (a) Supervisor (a) de Assistência Social, e nos termos da legislação em vigor;

2. Manter acompanhamento dos relatórios de visitas do técnico supervisor responsável, obedecidas às normas técnico-operacionais, assegurando seu acesso aos órgãos técnicos da Secretaria de Assistência e Desenvolvimento Social;

3. Indicar padrões básicos para o desenvolvimento das atividades objeto do convênio, assim como a necessidade de treinamento e reciclagem de pessoal;

4. Disponibilizar mensalmente os recursos financeiros para realização do repasse mensal à CONVENIADA, conforme portaria específica para pagamento e prestação de contas de SMADS;

5. Examinar e aprovar as prestações de contas dos recursos financeiros repassados à CONVENIADA, fiscalizando o adequado uso da verba e o cumprimento das cláusulas do convênio;

6. Realizar o pagamento das despesas de aluguel e impostos inerentes ao imóvel destinado ao referido serviço, quando for o caso, e arcar com as reformas estruturais, de hidráulica e de elétrica das instalações físicas, quando se tratar de serviço instalado em próprio municipal;

7. Fornecer placa de identificação oficial, a ser colocada no local da prestação do serviço, informando sobre a presente ação conveniada;

8. Manter relação de referência/ contrareferência entre o CRAS - Centro de Referência de Assistência Social e CREAS - Centro de Referência Especializado de Assistência Social e as vagas do serviço, conveniado;

9. Garantir a qualificação dos recursos humanos que operam os serviços, programas ou projetos em parceria;

10. Oferecer apoio técnico e operacional para garantir a qualidade das atenções de assistência social;

11. Assegurar a elaboração de modelo padrão de termo de compromisso e responsabilidade tripartite, a ser firmada entre o usuário, a CONVENIADA e SMADS, de acordo com o disposto na alínea "b" do inciso II do artigo 22 do Decreto Municipal n. ${ }^{\circ}$ 43.698/03, e receber e apreciar eventual manifestação dos usuários em defesa de seus direitos;

12. Manutenção de bancos de dados como parte do Sistema Único de Assistência Social SUAS.

CLÁUSULA QUARTA - São atribuições da Supervisão de Assistência Social (SAS)

1. Participar da seleção dos profissionais que atuarão no objeto deste convênio;

Elaborado pela SMADS/CPC em abril/2016 14

2. Participar de capacitações continuadas, tanto as oferecidas pela SMADS, como as viabilizadas pela rede local;

3. Monitorar, avaliar a prestação dos serviços do serviço objeto deste convênio;

4. Realizar a supervisão da prestação de contas e do serviço conveniado;

5. Elaborar Plano de Supervisão Técnica para acompanhamento, monitoramento e avaliação do serviço.

\section{IV - DAS OBRIGAÇÕES DA CONVENIADA}

CLÁUSULA QUINTA - São obrigações da CONVENIADA, em consonância com o art. 22 do Decreto Municipal $n . .43 .698$, de 02 de setembro de 2003:

1. Executar o serviço, assistencial discriminado na cláusula segunda, a quem deles necessitar, na conformidade da proposta de trabalho selecionada;

2. Garantir padrão de qualidade das ações e promover a implantação das sugestões de alteração ou de complementação das ações, de acordo com as diretrizes técnicas e operacionais definidas pela SMADS, e com as propostas apresentadas pelos usuários e pela comunidade; 
3. Proporcionar amplas e iguais condições de acesso à população abrangida pelo serviço assistencial, sem discriminação de qualquer natureza, zelando pela segurança e integridade física dos usuários;

4. Prestar todo e qualquer esclarecimento ou informação, relativamente ao objeto do presente convênio, solicitado pelas Supervisões de Assistência Social, Secretaria de Assistência e Desenvolvimento Social, membros da Câmara Municipal, Conselho Municipal de Assistência Social e demais órgãos públicos competentes, assegurando as condições necessárias ao acompanhamento, supervisão, fiscalização e avaliação da execução e dos resultados deste convênio;

5. Aplicar integralmente os recursos financeiros repassados pela SMADS na prestação das ações objeto deste convênio, conforme estabelecido na cláusula segunda;

6. Adotar os procedimentos estabelecidos em portaria específica para prestação de contas de SMADS, mantendo, por cinco anos, sobcustódia, a documentação comprobatória.

7. Manter a contabilidade, os procedimentos contábeis dos recursos recebidos de SMADS e os registros estatísticos de atendimento de forma que permitam a comprovação da regularidade da aplicação dos recursos públicos;

8. Manter recursos humanos, materiais e instalações adequados e compatíveis com o atendimento das ações assistenciais, com vistas ao alcance dos objetivos deste convênio;

9. Contratar e manter, por sua conta, pessoal qualificado e necessário ao desenvolvimento do serviço, conforme as orientações técnicas de SMADS, comprometendo-se a cumprir a legislação vigente;

10. Realizar capacitação continuada junto aos profissionais da CONVENIADA a fim de assegurar a execução do plano de trabalho aprovado em audiência pública, avaliação sistemática para a prestação do serviço com qualidade dentro da política de assistência social;

11. Alimentar os sistemas de controle de dados dos serviços, informatizados ou manuais, adotados pela SMADS, bem como os decorrentes das normas expedidas pela União e pelo Governo do Estado de São Paulo;

12. A CONVENIADA deverá fornecer, mensalmente, relação contendo informações individualizadas das pessoas atendidas durante o mês, na forma que vier a ser estabelecida por SMADS,

13. Manter placa de identificação afixada no imóvel onde funciona o serviço conveniado, de acordo com especificações estabelecidas pela Secretaria Municipal de Assistência e Desenvolvimento Social;

14. Mencionar, em toda publicação, material promocional e de divulgação de suas atividades e eventos, que a atividade é mantida em convênio com a Prefeitura do Município de São

Elaborado pela SMADS/CPC em abril/2016 15

Paulo; (inserir o texto "com o Governo do Estado e/ou com a União" quando o repasse mensal for composto por recursos dessas esferas);

15. Manter a identidade do trabalhador social mediante crachá contendo nome completo, cargo, função e logomarca da organização e da Prefeitura;

16. Manter avaliação da qualidade das atenções prestadas, conjuntamente com os usuários, conforme estabelece o artigo 11, inciso III da Lei Municipal n. $\stackrel{0}{13.153}$, de 22 de junho de 2001;

17. Manter, durante o prazo de vigência deste convênio, a regularidade das obrigações perante a Previdência Social e o Fundo de Garantia do Tempo de Serviço;

18. Comunicar à Supervisão de Assistência Social toda e qualquer alteração ocorrida em seus estatutos sociais, mudanças de diretoria ou substituição de seus membros;

19. Manter atualizado diariamente o Banco de Dados dos Usuários e de suas Famílias, de acordo com as normas expedidas pela União e pelo Governo do Estado de São Paulo, bem como deverá alimentar os sistemas de controles de dados dos serviços - on line, informatizados ou manuais - adotados por SMADS;

20. Se atentar às vedações previstas na Lei Municipal no 15.089 , publicada no DOC de 29/12/2009, parágrafo $2^{\circ}$ do artigo 14 e Súmula Vinculante ํㅜ 13 do Supremo Tribunal 
Federal, que trata da vedação da contratação de cônjuge, companheiro ou parente em linha reta, colateral ou por afinidade até o terceiro grau para execução dos serviços públicos, a qual se aplica às entidades conveniadas com a PMSP.

CLÁUSULA SEXTA - São atribuições da CONVENIADA:

1. Realizar diagnóstico, mapeando os serviços conveniados ou não, localizando a rede de serviços a partir dos territórios de maior incidência de vulnerabilidade e riscos, de forma a propiciar a universalidade de cobertura entre indivíduos e famílias;

2. Elaborar Plano de Ação seguindo as diretrizes do PLAS/SP em vigor;

3. Participar da capacitação continuada tanto as oferecidas pela SMADS, como as viabilizadas pela rede local;

4. Possuir tecnologia para operar o banco de dados informatizado das famílias alvo do Programa, com acesso à Internet, pelo menos um computador com a seguinte configuração mínima: $256 \mathrm{MB}$ de memória, processador $1.8 \mathrm{GHZ}$, superior ou equivalente, com Internet Explorer 6.0 ou superior, e Windows XP ou versão mais atualizada do Windows e impressora;

5. Possibilitar que a SAS acompanhe a seleção dos profissionais do serviço, de acordo com as atribuições exigidas para cada função apresentadas na Portaria 46/2010/SMADS;

6. Realizar as ações previstas no plano de trabalho, respeitando as diretrizes e eixos dos serviços;

7. Responsabilizar-se pela manutenção, reforma e ampliação do espaço físico; (quando tratar de imóvel cedido pela organização - próprio ou alugado)

8. Zelar pelo imóvel municipal ou locado pela Municipalidade e responsabilizar-se por sua manutenção; (quando tratar de imóvel próprio municipal, locado com repasse, locado por SMADS)

9. Zelar pelos bens móveis municipais, ficando como gerenciadora e, na pessoa de seu representante legal, como fiel depositária dos mesmos, responsabilizando-se pela necessária manutenção, pequenos reparos e reposição dos mesmos ressalvados 0 desgaste pelo tempo de uso, devendo, ainda, mantê-los em adequadas condições de uso e perfeito funcionamento e restituindo-os, por fim, nas mesmas condições de sua entrega, uma vez findado ou rescindido o convênio, quando ocorrer fornecimento de bens móveis pela SMADS.

10. Participar da sistematização, monitoramento das atividades desenvolvidas e do processo de avaliação;

Elaborado pela SMADS/CPC em abril/2016 16

11. Disponibilizar o conhecimento gerado entre as demais organizações conveniadas para o serviço, bem como entre as Coordenadorias de Assistência Social e SMADS por meio de encontros e seminários, relatórios e boletins informativos;

12. Cadastrar, quando necessário, as famílias no BDC ou outro instrumental definido pela SMADS, conforme especificações estabelecidas pela Portaria no 004/SMADS/SMSP/SMG de 19/09/2005;

13. Publicizar a parceria com material fornecido pela SMADS e pela Organização e garantir a presença dos logos da PMSP e da SMADS nos materiais elaborados pela organização, tais como, folders, banners, convites, outros meios impressos e demais mídias.

Parágrafo Único - A relação dos bens municipais de que trata o "item 08", devidamente caracterizados e identificados por meio do Inventário Analítico de Bens Móveis Municipais, é parte integrante do presente termo, independente de transcrição.

$\checkmark$ - DO CUSTEIO

CLÁUSULA SÉTIMA - O custeio do objeto deste convênio será composto pelos valores referentes a:

1. Verba de Implantação;

2. O repasse mensal; 
3. As despesas pagas por SMADS diretamente; (manter o item somente quando SMADS celebra diretamente o contrato de locação para desenvolvimento do serviço ou quando SMADS paga diretamente concessionárias de serviços públicos e taxas).

Parágrafo Único: A estimativa da composição do custeio mensal do objeto deste convênio está discriminada no "Demonstrativo do Custeio do Serviço Conveniado", parte integrante deste termo como ANEXO ÚNICO.

CLÁUSULA OITAVA - Para a implantação do objeto deste convênio, conforme demonstração constante da proposta de trabalho aprovada, a CONVENIADA receberá uma única vez, o valor de $\mathrm{R} \$$ (POR EXTENSO) como verba de implantação.

Parágrafo Primeiro - $\mathrm{O}$ valor estipulado no caput desta cláusula será repassado pela SMADS, mediante crédito em conta corrente da CONVENIADA, especificamente aberta para a execução deste convênio, após a assinatura do termo de convênio.

Parágrafo Segundo - Para recebimento da verba da implantação e início dos serviços, a organização conveniada deverá solicitá-la, por meio de requerimento específico, após a formalização do Termo de Convênio, à Supervisão de Assistência Social - SAS, detalhando a forma de utilização do recurso conforme disposto no Art. 7ํ da Portaria 006/SMADS/2016; Parágrafo Terceiro - A utilização do recurso referente à verba de implantação e a sua prestação de contas deverá ser realizada em até 65 (sessenta e cinco) dias após o efetivo recebimento dos recursos pela organização conveniada e será formalizada nos mesmos autos do processo de prestação de contas da verba mensal do convênio, por meio do "Demonstrativo de Gerenciamento dos Recursos Financeiros - Verba de Implantação", cujo modelo integra o Anexo Único da Portaria 006/SMADS/2016. Eventual saldo não utilizado ou não aprovado na prestação de contas deverá ser devolvido à Municipalidade no prazo improrrogável de 30 dias.

CLÁUSULA OITAVA / NONA - A SMADS repassará mensalmente à CONVENIADA o valor de $R \$$ composto por: relativo à execução do serviço objeto deste convênio, sendo

1. Verbas disponibilizadas por SMADS dentro do seu próprio orçamento.

Elaborado pela SMADS/CPC em abril/2016 17

2. Verbas decorrentes de repasse feito pelo Governo do Estado à SMADS, que serão disponibilizadas após o depósito no FMAS do valor correspondente em conta específica. (manter este item somente quando o repasse mensal for composto por recursos de fonte estadual)

3. Verbas decorrentes de repasse feito pela UNIÃO à SMADS, que serão disponibilizadas após o depósito no FMAS do valor correspondente em conta específica. (manter este item somente quando o repasse mensal for composto por recursos de fonte federal)

Parágrafo Primeiro - O valor estipulado no caput desta cláusula será repassado pela SMADS mensalmente, mediante crédito em conta corrente da CONVENIADA aberta para a execução do convênio, relativo à execução do serviço objeto deste convênio, até o $5^{\circ}$ dia útil de cada mês da execução, vinculado ao depósito dos respectivos recursos no Fundo Municipal de Assistência Social. Excepcionalmente, no mês de janeiro de cada exercício, o pagamento será efetuado assim que ocorrer a abertura do Sistema de Orçamento e Finanças - SOF e houver a liberação das cotas financeiras por parte da Secretaria Municipal de Finanças e Desenvolvimento Econômico.

Parágrafo Segundo - Para ocorrer o repasse mensal, a organização conveniada deverá apresentar a prestação de contas, nos termos do capítulo VI - DOS PROCEDIMENTOS DA PRESTAÇÃO DE CONTAS deste Termo.

Parágrafo Terceiro - No caso de existir verba disponibilizada para a contrapartida municipal, a liberação dos recursos correspondentes poderá ser efetuada independente do pagamento dos recursos de outras esferas.

Parágrafo Quarto - O valor estipulado no caput poderá ser reduzido no montante correspondente ao custeio com a prestação do serviço, mantida a remuneração dos 
recursos humanos e demais custos fixos, no caso de reforma inadiável do imóvel, com o consentimento da SMADS, pelo período correspondente à interrupção do atendimento.

Parágrafo Quinto - Caso venha a ocorrer à necessidade de providências complementares pela CONVENIADA a pedido de SMADS, o pagamento ficará suspenso até o saneamento das impropriedades.

\section{SOMENTE PARA TERMOS SAICAS}

Parágrafo Sexto - O pagamento das vagas aditadas na Operação Baixas Temperaturas será liberado somente de acordo com os dados registrados no SISRUA e mediante o monitoramento do técnico.

Parágrafo Sétimo - O custeio mensal prevê a contratação de educativo(s) além do padrão, sendo durante o período de acolhimento de para o período diurno e orientador (es) sócioParágrafo Oitavo: A conveniada fica obrigada a comunicar à SMADS/SAS, no prazo de até 72 horas, o desacolhimento que levou ao presente aditamento e eventual substituição da criança/adolescente por outra em igual condição, devendo tais circunstâncias estar devidamente comprovadas nos autos.

Parágrafo Nono: O acréscimo ora concedido ficará automaticamente cessado em caso de desacolhimento ou atingimento de idade de 01 ano, quando for o caso, sem substituição da criança/adolescente, respeitado eventual aviso prévio em conformidade com a legislação trabalhista. Elaborado pela SMADS/CPC em abril/2016 18

Só colocar esta cláusula quando SMADS pagar além do repasse mensal, o aluguel do imóvel, concessionárias, impostos e taxas,

CLÁUSULA NONA / DÉCIMA - Além do repasse mensal indicado na cláusula anterior, o custeio mensal do objeto deste convênio será composto também pelos recursos financeiros disponibilizados diretamente pela SMADS para a prestação do serviço, considerados os casos em que a própria SMADS celebra diretamente o contrato de locação do imóvel em que o objeto do convênio será executado, bem como os casos em que a SMADS paga diretamente as despesas das concessionárias públicas, taxas e impostos relativos ao imóvel em que o objeto do convênio é prestado.

Parágrafo Unico - Os recursos financeiros referidos no caput desta cláusula correspondem ao valor total mensal de $R \$$

(o valor será

igual à soma do item "a" + "b" + "c"), sendo que compõem este valor as seguintes despesas:

a) valor do aluguel do imóvel: $R \$$ (valor por extenso);

b) estimativa de despesa mensal com concessionárias públicas: $R \$$ (valor por extenso);

c) despesa mensal com taxas e impostos: $R \$$

VI - DOS PROCEDIMENTOS DA PRESTAÇÃO DE CONTAS

(valor por extenso).

CLÁUSULA NONA / DÉCIMA / PRIMEIRA - O primeiro repasse após a celebração do Termo do Convênio será efetivado independentemente da apresentação de prestação de contas, a qual se dará no mês subsequente, salvo quando se tratar de continuidade de serviço anteriormente prestado pela mesma organização conveniada. A partir do segundo repasse, a Conveniada deverá apresentar todos os documentos para a prestação de contas referente ao mês anterior.

CLÁUSULA DÉCIMA / PRIMEIRA / SEGUNDA - A prestação de contas mensal se dará de forma presencial, junto à Supervisão de Assistência Social / Unidade de Prestação de Contas (SAS/UPC), de acordo com prévio agendamento feito pela Supervisão de Assistência Social (SAS).

CLÁUSULA DÉCIMA PRIMEIRA / SEGUNDA / TERCEIRA - Para a prestação de contas, a CONVENIADA deverá apresentar os seguintes documentos até o dia 20 de cada mês ou no primeiro dia útil subsequente quando este cair em sábado, domingo, feriado ou ponto facultativo.

a) requerimento assinado pelo Presidente, ou representante legal encaminhando a prestação de contas;

b) nota fiscal da organização da prestação de serviços;

c) Declaração Mensal de Execução dos Serviços (DEMES), referente ao mês anterior; 
d) Descrição Mensal de Despesas (DESP), referente às despesas realizadas na segunda quinzena do mês anterior com os respectivos comprovantes (original e cópia);

e) Declaração Mensal de Despesas - Recursos Humanos (DESP-RH), referente ao mês anterior com os respectivos comprovantes (original e cópia);

f) Declaração de Movimentação Financeira Mensal (DEMOFIM), referente ao mês anterior.

CLÁUSULA DÉCIMA SEGUNDA / TERCEIRA / QUARTA - Eventual saldo devido à Municipalidade após a última prestação de contas havida no convênio deverá ser devolvido Elaborado pela SMADS/CPC em abril/2016 19

em até 20 dias contados desta, por meio de Documento de Arrecadação do Município de São Paulo (DAMSP), salvo em caso de celebração de novo convênio em continuidade devidamente assinado - pela mesma organização conveniada.

CLÁUSULA DÉCIMA TERCEIRA / QUARTA / QUINTA - O protocolo deverá ser feito junto à Unidade de Prestação de Contas (UPC) da Supervisão de Assistência Social (SAS) que autenticará e reterá as cópias dos comprovantes de despesas e devolverá as vias originais à conveniada.

CLÁUSULA DÉCIMA QUARTA / QUINTA / SEXTA - Caberá a Supervisão de Assistência Social (SAS) mensalmente:

a) Estabelecer agendamento mensal de atendimento às organizações conveniadas para a prestação de contas;

b) Receber as prestações de contas nas datas estabelecidas;

c) Efetuar as conferências no âmbito das respectivas competências do Técnico Supervisor do Serviço e da Unidade de Prestação de Contas já estabelecidas em legislações anteriores, carimbando, assinando e datando o verso dos comprovantes apresentados, bem como especificando eventuais fracionamentos de despesas, se for o caso;

d) Encaminhar Planilha de Liquidação (PL) para a Secretaria Municipal de Assistência e Desenvolvimento Social / Assessoria Técnica Financeira / Supervisão Técnica de Contabilidade (SMADS/ATF/STC) dos serviços cujas organizações apresentarem prestação de contas a partir do $21^{\circ}$ dia de cada mês ou no primeiro dia útil subsequente quando este cair em sábado, domingo, feriado ou pontos facultativo.

e) Deliberar sobre a prestação de contas do mês anterior até o dia 20 de cada mês ou no primeiro dia útil subsequente quando cair em sábado, domingo, feriado ou ponto facultativo e inscrever eventuais valores glosados na Declaração de Movimentação Financeira Mensal (DEMOFIM) do mês subsequente.

CLÁUSULA DÉCIMA SÉTIMA / OITAVA / NONA - O período concernente à utilização de recursos financeiros para pagamento das ações conveniadas será de um ano, dentro do qual se o valor do repasse mensal do convênio não for gasto integralmente no mês correspondente, o saldo por elemento de despesa, poderá ser flexibilizado pela CONVENIADA para outro elemento, desde que observado os limites estabelecidos na legislação vigente ou remanejá-los para o mês subsequente no mesmo elemento de despesa.

1 - A utilização da anualidade dos recursos financeiros pela organização parceira tem como referências o mês de julho de um ano para início do período e junho do seguinte para final do período.

2 - A organização parceira adequará sua prestação de contas final para que corresponda ao mês final da anualidade, independente da data de início de vigência do serviço sobgestão conveniada.

3 - Mensalmente a conveniada deverá apresentar a movimentação financeira através da DEMOFIM e anualmente o ajuste final através da DEGREF ANUAL.

4 - Havendo saldo positivo na DEGREF ANUAL o mesmo será descontado no repasse do mês de agosto da anualidade seguinte. Ocorrendo saldo negativo, o mesmo será considerado contrapartida da ORGANIZAÇÃO.

Parágrafo Primeiro - Na hipótese dos gastos excederem ao valor do repasse mensal do convênio, a CONVENIADA poderá receber a diferença no mês seguinte, desde que haja 
saldo não utilizado remanescente no trimestre, vedada a compensação de quantias gastas a maior e o menor findado cada trimestre. Elaborado pela SMADS/CPC em abril/2016 20

Parágrafo Segundo - Os saldos remanescentes de valores repassados pela SMADS e não gastos pela CONVENIADA deverão ser aplicados em caderneta de poupança de instituição financeira oficial, se a previsão de seu uso for igual ou superior a um mês, ou em fundo de aplicação financeira de instituição oficial, quando a utilização dos recursos, verificar-se em prazos inferiores há um mês, nos termos do parágrafo $4^{\circ}$, do art. 116 , da Lei Federal n.은 8.666, de 21 de junho de 1993, devendo as receitas auferidas, dos referidos investimentos, serem aplicadas exclusivamente no objeto deste convênio, constando de demonstrativo específico que integrará a prestação de contas, nos termos do parágrafo $5^{\circ}$, do mesmo dispositivo legal.

Parágrafo Terceiro - Em qualquer hipótese, findo o presente convênio, os saldos de recursos remanescentes, inclusive os provenientes das receitas obtidas das aplicações financeiras realizadas, serão devolvidos à SMADS, no prazo improrrogável de 30 dias, sobpena de imediata instauração de tomada de contas especial do responsável, nos termos do parágrafo 6을 do art. 116, da Lei Federal n. 8.666, de 21 de junho de 1993.

CLÁUSULA DÉCIMA OITAVA / NONA / VIGÉSIMA - Para o recebimento do repasse mensal a CONVENIADA deverá entregar:

1. MENSALMENTE:

Requerimento assinado pelo representante legal da organização solicitando pagamento pelo serviço prestado enquanto for regime de reembolso;

Requerimento assinado pelo representante legal da organização encaminhando prestação de contas do serviço prestado quando for regime de repasse;

$\square$ Declaração Mensal de Execução dos Serviços Socioassistenciais- DEMES;

Declaração Mensal de Despesas- DESP;

Declaração de movimentação Financeira Mensal- DEMOFIM;

Comprovante das despesas realizadas;

Certidões.

2. SEMESTRALMENTE:

$\square$ Grade de Atividades Semestral- GRAS que deverá ser apresentada semestralmente, até

o dia 15 de dezembro correspondente às atividades para o primeiro semestre do ano subsequente e 15 de junho para as atividades do segundo semestre contendo 0 planejamento das atividades baseadas nas ofertas socioassistenciais, a previsão de horas técnicas e oficinas e deverá ser ratificada pelo técnico supervisor.

3. ANUALMENTE

- Declaração de Férias Coletivas (para os serviços com esta possibilidade);

$\square$ Declaração de Gerenciamento dos Recursos Financeiros- DEGREF ANUAL.

\section{VII - DO GERENCIAMENTO, DO CONTROLE E DA AVALIAÇÃO DA EXECUÇÃO DO} CONVÊNIO.

CLAUSULA DÉCIMA NONA / VIGÉSIMA / PRIMEIRA - O controle e a avaliação da execução do presente convênio ficarão a cargo da SMADS, órgão responsável pela execução da política de assistência social no município de São Paulo.

Parágrafo Primeiro - Os Conselhos Municipais da Assistência Social e dos Direitos da Criança e do Adolescente poderão, de acordo com as suas atribuições legais, realizar a avaliação do objeto do presente convênio.

Parágrafo Segundo - O controle e a avaliação da execução do presente convênio tomarão como base o cumprimento dos padrões das ofertas que compõem o objeto deste Termo, o cumprimento das diretrizes do Plano Municipal de Assistência Social - PLAS-SP, a garantia Elaborado pela SMADS/CPC em abril/2016 21

dos direitos dos usuários e a boa e fiel utilização dos recursos financeiros pagos pela SMADS à CONVENIADA.

VIII - DAS PENALIDADES 
CLÁUSULA VIGÉSIMA / PRIMEIRA / SEGUNDA - O não cumprimento das cláusulas deste convênio, bem como a inexecução injustificada, total ou parcial, dos serviços, programas e projetos conveniados constituem irregularidades passíveis das seguintes penalidades, aplicadas cumulativamente e/ou progressivamente, obedecida a proporcionalidade:

1. Advertência formal;

2. Suspensão do repasse mensal;

3. Suspensão da Matrícula / Credenciamento;

4. Rescisão do Convênio;

5. Cancelamento da Matrícula / Credenciamento.

Parágrafo Primeiro - Constatada pela SUPERVISÃO DE ASSISTÊNCIA SOCIAL - SAS a ocorrência de irregularidades, a CONVENIADA deverá ser por essa cientificada, por meio de notificação formal, no prazo máximo de 5 (cinco) dias úteis.

Parágrafo Segundo - A CONVENIADA deverá apresentar, no prazo máximo de 5 (cinco) dias úteis, a partir da data do recebimento da notificação de irregularidades, justificativa e proposta de correção para apreciação e decisão da SUPERVISÃO DE ASSISTÊNCIA SOCIAL - SAS.

Parágrafo Terceiro - A liberação do pagamento será feita após a correção das irregularidades apontadas, ou da aceitação formal da proposta de correção, com prazos determinados.

Parágrafo Quarto - A cópia da notificação de ocorrências de irregularidades, devidamente assinada pelas partes, da justificativa e da proposta de correção integrarão o processo administrativo identificado no preâmbulo do presente Termo.

Parágrafo Quinto - Quando for aplicada penalidade, deve ser o ato publicizado no Diário Oficial da Cidade (DOC).

IX - DA VIGÊNCIA E ALTERAÇÕES

CLÁUSULA VIGÉSIMA PRIMEIRA / SEGUNDA / TERCEIRA - O presente convênio terá duração de 24 (vinte e quatro) meses, da data de ___ _ _ _ a _ _ _ _ _ _ podendo ser prorrogado, mediante ato específico do Secretário Municipal de Assistência e Desenvolvimento Social publicado no Diário Oficial do Município de São Paulo, por menor, igual ou maior período, desde que não exceda no total, o prazo de 60 (sessenta) meses, nos termos da legislação vigente.

CLÁUSULA VIGÉSIMA SEGUNDA / TERCEIRA / QUARTA - O convênio poderá ser aditado, por acordo entre os partícipes, nos casos de:

I - alteração do serviço executado;

II - acréscimo ou redução do número de atendidos, com a consequente alteração do valor do pagamento mensal.

CLÁUSULA VIGÉSIMA TERCEIRA / QUARTA / QUINTA - Fica convencionado que a SMADS poderá alterar, mediante ato específico do Secretário Municipal de Assistência e Desenvolvimento Social publicado no Diário Oficial da Cidade de São Paulo, o valor do pagamento mensal, desde que comprovada sua inadequação, por meio de estudos de custos, e Elaborado pela SMADS/CPC em abril/2016 22 desde que existam recursos orçamentários disponíveis, mediante a junção aos autos de cópia do provimento autorizatório.

X - DA RESCISÃO E DA DENÚNCIA

CLÁUSULA VIGÉSIMA QUARTA / QUINTA / SEXTA - Este convênio poderá, a qualquer tempo e por iniciativa de qualquer dos partícipes, ser denunciado mediante notificação prévia de 60 (sessenta) dias.

CLÁUSULA VIGÉSIMA QUINTA / SEXTA / SÉTIMA - O presente convênio poderá, ainda, ser rescindido, independentemente do prazo previsto na cláusula anterior, nos seguintes casos:

1. A qualquer tempo, por mútuo acordo, mediante a lavratura do Termo de Rescisão.

2. Unilateralmente, de pleno direito e a critério da SMADS, mediante denúncia e notificação formal: 
2.1. Por irregularidades referentes à administração dos valores recebidos, bem como à execução do objeto ou cláusulas do convênio relativo ao desenvolvimento do serviço e ao cumprimento dos padrões estabelecidos nas normas gerais para celebração de convênio de SMADS, constatadas pela SUPERVISÃO DE ASSISTÊNCIA SOCIAL - SAS;

2.2. Por descumprimento, pela CONVENIADA, de qualquer disposição prevista nas cláusulas deste convênio.

2.3. Em razão de denúncia ou RESCISÃO do convênio mantido com a Secretaria Estadual de Assistência e Desenvolvimento Social e/ou com o Ministério do Desenvolvimento Social e Combate à Fome.

\section{XI - DOS RECURSOS FINANCEIROS}

CLÁUSULA VIGÉSIMA SEXTA / SÉTIMA / OITAVA - A execução do presente convênio onerará a dotação orçamentária $n$. - 93.10.08.243.3013.6221.3.3.50.39.00.0X - PROTEÇÃO ESPECIAL A CRIANÇAS, ADOLESCENTES E JOVENS EM RISCO SOCIAL, a conta do Fundo Municipal de Assistência Social, no valor total de $\mathrm{R} \$$ as dotações orçamentárias correspondentes que forem estabelecidas nos exercícios seguintes.

XII - DA LEGISLAÇÃO APLICÁVEL E DO FORO

CLÁUSULA VIGÉSIMA SÉTIMA / OITAVA / NONA - Aplica-se ao presente convênio a Lei Municipal $\mathrm{n} \square$ 13.153/2001, o Decreto Municipal n. ${ }^{\circ}$ 43.698/03, a Portaria n. ${ }^{0}$ 31/2003/SAS/GABINETE e as demais normas e orientações oriundas da SMADS, e, no que couberem, as disposições da Lei Federal $\mathrm{n} \square$ 8.666/93.

.2 CLÁUSULA VIGÉSIMA OITAVA / NONA / TRIGÉSIMA - Fica eleito o Foro da Comarca de São Paulo para dirimir quaisquer questões resultantes da execução deste convênio.

E, por estarem de acordo com as cláusulas e condições ajustadas, firmam o presente termo de convênio em 04 (quatro) vias de igual teor, na presença das testemunhas abaixo dentificadas.

São Paulo, _ de 2016. (nome do supervisor da SAS)

de (nome do

representante legal da

Supervisor (a) ${ }^{12}$

${ }^{12}$ Edital elaborado pela Secretaria Municipal de Assistência e Desenvolvimento Social em abril/2016. 


\section{Rubens de Camargo Ferreira Adorno}

(⿶) Endereço para acessar este CV: http://lattes.cnpq.br/7427719296567082

恼 Última atualização do curríulo em 22/08/2018

Professor Senior da Faculdade da Saúde Pública da Universidade de São Paulo, graduado em Ciências Socias pela UNICAMP, Mestre de Doutro em Saúde Pública pela USP, Livre Docente (1997). Vem atuando na linha de pesquisa: Saúde Pública, Ciências Sociais e Sociedade Contemporânea; que procura trazer a contribuição da Pesquisa Social, notadamente da Antropologia e de uma Antropologia Crítica da Saúde, buscando construir um tratamento teórico para as vulnerabilidades contemporâneas; que possam se expressar a partir dos contextos e das subjetividades, suas relações com o consumo, as moralidades e as políticas públicas que se constituem no capitalismo tardio e articulam os contextos globais, nacionais e locais. Tem como campo de pesquisa as mudanças que ocorrem na vida das populações a partir de seus contextos e dos recortes classe social, raça-etnia, geração, gênero e sexualidades e curso de vida, assim como as questões que envolvem as biopolíticas, biolegitimidades e políticas da vida, considerando o fato de que as intervenções no campo da saúde que supõem uma neutralidade técnica, ignoram significados, sentidos e contextos vividos envolvendo fenômenos mais complexos e mais amplos. As pesquisas mais recentes têm tematizado o campo das drogas lícitas, ilícitas ou prescritas , como uma esfera do consumo das sociedades contemporâneas a partir do desafio de propor uma abordagem mais complexa do que o tratamento técnico a que esses fenômenos são relegados. (Texto informado pelo autor)

Identificação

Nome Rubens de Camargo Ferreira Adorno

Nome em citações bibliográficas ADORNO, R. C. F.;Adorno, Rubens de Camargo Ferreira;ADORNO, RUBENS CAMARGO FERREIRA

Endereço

Endereço Profissional Universidade de São Paulo, Faculdade de Saúde Pública.

AV. DR. ARNALDO N0 715

CERQUEIRA CÉSAR

Paulo, SP - Brasi

Telefone: (11) 30617971

Formação acadêmica/titulação

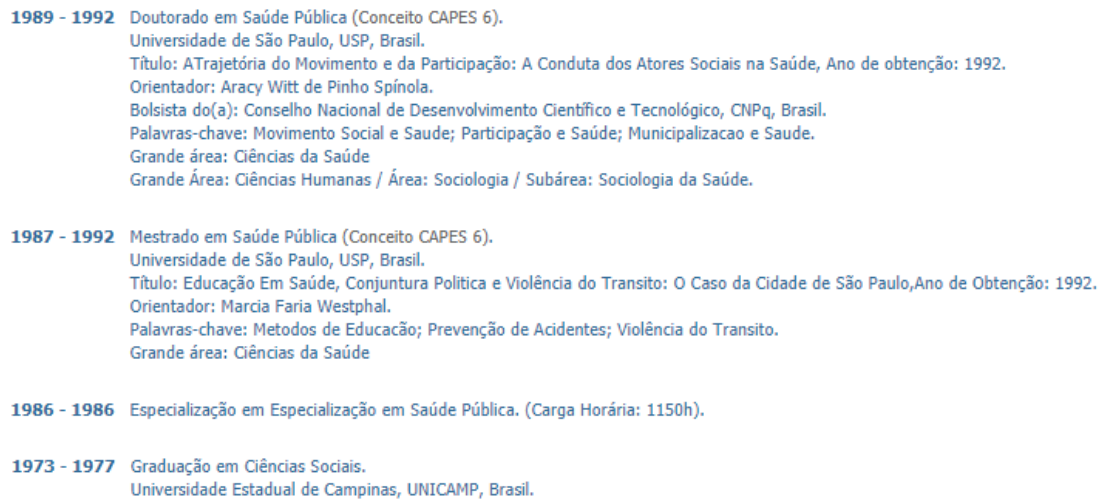

Pós-doutorado e Livre-docência

1997 Livre-docência.

Universidade de São Paulo, USP, Brasil.

Titulo: Qualidade de Vida e Formas de Vida Ameaçadas: a saúde e c cenárioo contemporâneo, Ano de obtenç̃o: 1997.

Palavras-chave: Saociedade Contemporanea; Reflexividade Social; Exclusão Social; Saúde Pública.

Grande área: Ciências da Saúde

Grande Área: Ciências Humanas / Área: Sociologia / Subárea: Sociologia da Saúde.

2000 - 2001 Pós-Doutorado.

Hôpital Marmottan / CADIS Ecole des Hautes Etudes en Sciences Sociales, H.M, França.

Bolsista do(a): COFECUB/USP, COFECUB/USP, Brasil.

Atuação Profissional

Universidade de São Paulo, USP, Brasil.

Vínculo institucional

2013 - Atual Vínculo: Servidor Público, Enquadramento Funcional: Professor Associado III, Regime: Dedicacão exclusiva.

Vínculo institucional

1985 - Atual Vínculo: Sevidor Público, Enquadramento Funcional: PROFESSOR ASSOCIADO, Carga horária: 40, Regime: Dedicaç̃o exclusiva. 


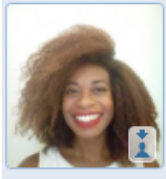

Patrícia Martins Khattar

(5) Endereço para acessar este CV: http://lattes.cnpq.br/2541459947245511

(a) Última atualização: 24/05/2019

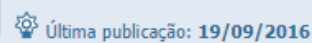

Psicóloga graduada pela Universidade Presbiteriana Mackenzie, especialista em Coordenação de Grupos e Equipes, com aprimoramento em Acompanhamento Terapêutico, atuante em intercâmbios profissionais transculturais na África, bem como no Rio de janeiro, no Morro do Borel, em comunidades quilombolas no Vale do Ribeira e na Fazenda de Picinguaba, além de comunidades indígenas na Amazônia. Com engajamento focado junto a população em situação de vulnerabilidade social, obteve experiência no Projeto Quixote, em Serviço de Acolhimento Infantojuvenil, inclusive em instituição de acolhimento de grupos familiares, denominado Familia em Foco. 0 âmbito de interesse da pesquisadora e palestrante consiste na perspectiva das Políticas Publicas de cuidado à pessoas em situação de risco social, Violência, Abuso e Exploração Sexual Infantojuvenil e acerca do uso abusivo de substâncias Psicoativas. (Texto informado pelo autor)

Identificação

Nome Patrícia Alves Martins

Nome em citações bibliográficas P. A. MARTINS

Endereço

Formação acadêmica/titulação

2007 - 2012 Graduação em Psicologia.

Universidade Presbiteriana Mackenzie, MACKENZIE, Brasil.

Titulo: 0 conceito de saúde entre psicólogos atuantes na área da dependência química.

Orientador: Dr Erich Montanar Franco.

Bolsista do(a): Universidade Presbiteriana Mackenzie, UPM, Brasil.

Formação Complementar

2013 Francês. (Carga horária: 100h)

Escola Técnica Camargo Aranha, ETEC MOocA, Brasil.

2012 Criança e Adolescente em Risco Social. (Carga horária: 100h). Projeto Quixote Área de Formação e Pesquisa, OSCIP PROJ QXT, Brasil.

2013 - 2013 Saúde Mental, Dependência Química e TDAH. (Carga horária: 50h). Santa Casa de Misericórdia de São Paulo, SCM/SP, Brasil.

2011 - 2011 Extensão universitária em Formação Cidadã - Escola de Governo. (Carga horária: 72h). Universidade de São Paulo, USP, Brasil.

Atuação Profissional

Projeto Quixote, PROJETO QUIXOTE, Brasil.

Vínculo institucional

2015 - Atual Vínculo: Autônomo, Enquadramento Funcional: Psicóloga, Carga horária: 20

Outras informacōes Instituição: Consultório Particular na Vila Mariana Psicoterapia para crianças, adolescentes, adultos e idosos, por meio de estimulação para habilitar ao saudável desenvolvimento biopsicossocial, em articulação com atendimento familiar. Experiência com Acompanhamento terapêutico em domicilio, escolas e ambientes externos ao consultório. Participação em entrevistas de rádio enquanto palestrante de temáticas concernentes à Psicologia Inclusive atuação com acompanhamento terapêutico e cuidado às crianças e adolescentes com Transtorno do Espectro Autista, disponibilizando consultas em consultório e domiclitio, bem como Acompanhamento Terapêutico em demais locais.

Vínculo institucional

2015 - 2015 Vínculo: Celetista, Enquadramento Funcional: Psicóloga, Carga horária: 40, Regime: Dedicação exclusiva.

Outras informações Instituição: SAICA Casa Ubuntu \& Casa das Expedições / Moradia Associação Civil Atribuições: Atuar no grupo gestor do serviço, coordenação e orientação da equipe de educadores e cuidadores do público atendido, entre crianças e adolescentes em situação de rua e de vulnerabilidade social. Responsável pelo acompanhamento individual e familiar, articulação da rede intersetorial. Palestrante e coordenadora de grupos temáticos de debates, dentre construção de eventos pedagógicos e culturais internos e externos, ao visar à autonomia e reintegração familiar, bem como participação em reuniões técnicas com equipe e com a rede de garantia de direitos.

Vínculo instituciona

2014 - 2014 Vínculo: Autônomo, Enquadramento Funcional: Psicóloga

Outras informações Instituição: Orquestra Cidadã / Associação Azarias Atribuições: Cuidado biopsicossocial às crianças e adolescentes em situação de vulnerabilidade e fortalecimento de vínculo familiar com atividades de instrução e ensino, ao ministrar palestras e aulas para tratar temáticas demandas, inclusive voltadas à inserção de adolescentes e jovens no mundo do trabalho. Realização de parcerias e desenvolvimento de palestras na rede de escolas do território. 